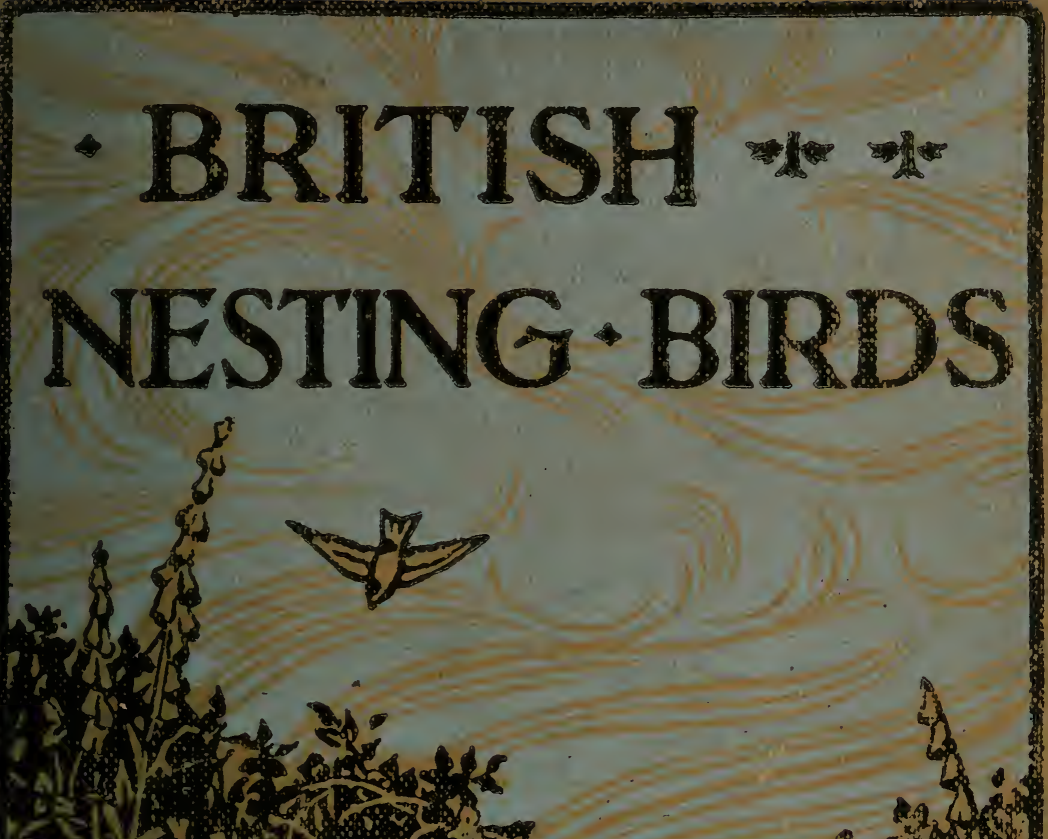
TSE

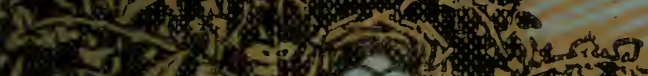

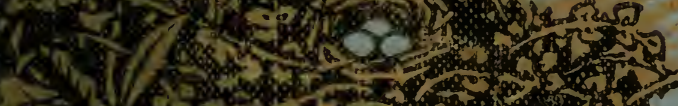

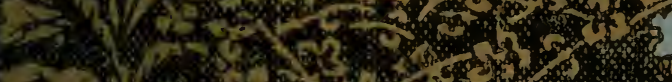

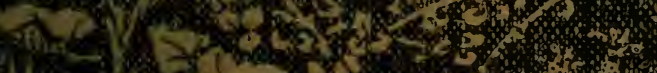

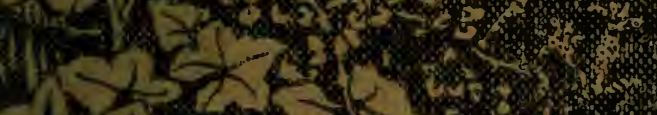

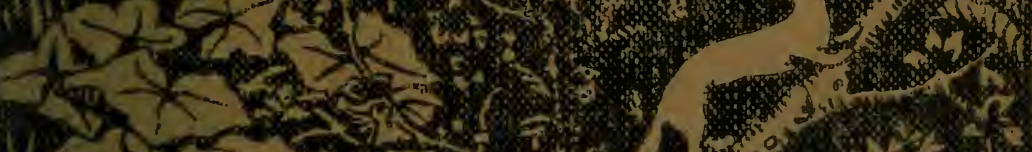

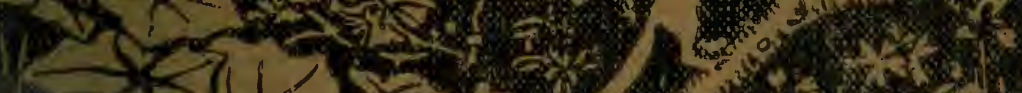

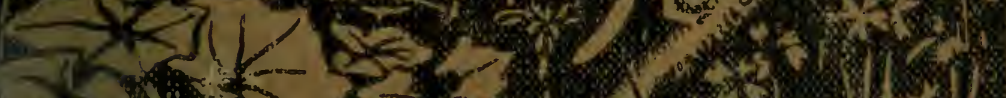

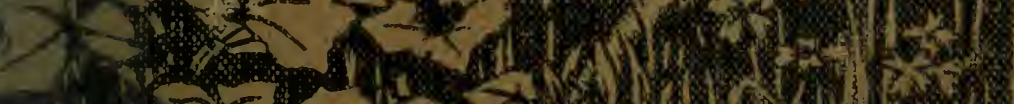

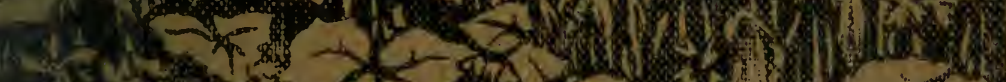
1. M n w w n

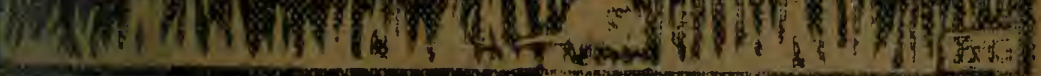




\section{LIBRARY OF THE}

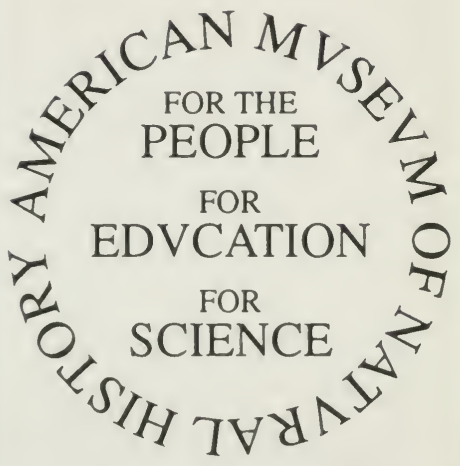




BRITISH NESTING BIRDS 




$$
\frac{x}{k}
$$




\section{BRITISH}

\section{NESTING BIRDS}

A COMPLETE RECORD OF EVERY SPECIES WHICH NESTS IN THE BRITISH ISLES

BY

W. PERCIVAL WESTELL

F.L.S., M.B.O.U.

Author of "Nature Stalking for Boys," etc., etc.

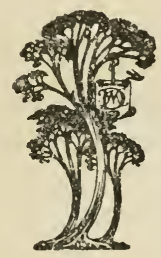

WITH

8 COLOURED

\& 70 BLACK AND WHITE

ILLUSTRATIONS

\section{$\operatorname{MCMX}$ \\ L O N D O N}

J. M. DENT \& SONS LTD. 



\section{PREFACE}

THE great interest taken in birds to-day, and the many inquiries which have reached me for a cheap, popular, and handy British Bird book, has resulted in the preparation of this little volume.

At best, the short account of each species is limited, but it is hoped that nevertheless many points will be found of interest and service to the student of our wild birds, and it is my fervent wish that many young people especially will be encouraged to observe the feathered population around us as a result of the publication of this book. I find there are many people interested in birds who rarely have an opportunity or the necessary knowledge or enthusiasm for studying them. On occasions, however, they do observe birds whose names they would like to know, and of whose life and habits they are desirous of acquiring some information. Primarily it is for these, and young people generally, that this book has been prepared. It will be found quite simple and understandable. Long scientific words have been omitted whenever possible, and when they have of necessity been used, they are included in a Glossary given on page 15 , where their meaning is made clear.

Attention may also be directed to the Index of more than one thousand local, old-fashioned, and correct names of birds, for by means of these it should be easy to trace any British nesting species even if only its local name is known.

Every species of wild bird at present known to nest in our country has been accorded a place, and whilst it affords satisfaction to be able to include the Little Owl, and to note the increase in a number of our smaller birds, such as the Goldfinch, Lesser Whitethroat, and others, there are several species included which are on the verge of extinction as British Nesting Birds, and need immediate protection. Any book on birds, worthy of the name, should prove most valuable as a work of reference. This it is hoped will be accomplished by the present volume, but it should be emphasised that the keenest and best enjoyment to be derived from birds, and the best way to study them, is having personal contact with them. This having been achieved, intelligent observation is bound to follow, and this in itself is sure to prove of inestimable value to those species which are threatened with extinction unless efforts are at once made to save them.

LETCHWORTH, HERTS,

W. PERCIVAL WESTELL.

Spring I9I0. 


\section{A LIST OF SUMMER MIGRANTS TO THE BRITISH ISLES RANGED SOMEWHAT IN THE ORDER IN WHICH THEY APPEAR}

I. Spotted Crake, March.

2. Ring Ouzel, end of March or early in Arpil.

3. Wheatear, end of March.

4. Stone Curlew, March, April, or early in May.

5. Chiff Chaff, end of March.

6. Yellow Wagtail, end of March or early in April.

7. Wryneck, end of March or early in April.

8. Sand Martin, early in April, usually before the Swallow or House Martin.

9. Swallow, middle of April.

10. Martin, about 2oth of April, generally a little later than the Swallow.

I I. Redstart, beginning to middle of April.

12. Grasshopper Warbler, middle of April.

I 3. Whinchat, from middle to end of April, sometimes as late as May.

14. Blackcap, middle of April.

I 5. Nightingale, middle of April.

16. Hobby Falcon, April.

17. Cuckoo, middle of April.

I 8. Tree Pipit, middle of April.

19. Common Sandpiper, middle of April.

20. Lesser Whitethroat, about middle of April.

21. Greater Whitethroat, about middle to end of April.

22. Willow Warbler, first or second week in April, sometimes earlier.

23. Kentish Plover, April or May.

24. Corncrake, last week in April.

25. Red-Backed Shrike, end of April or beginning of May.

26. Sedge Warbler, latter part of April.

27. Garden Warbler, end of April or early in May.

28. Reed Warbler, end of April or early in May.

29. Wood Warbler, end of April or early in May.

30. Turtle Dove, towards the end of April.

31. Quail, May.

32. Swift, early in May.

33. Marsh Warbler, about middle of May.

34. Spotted Flycatcher, 7 th to 20 th of May.

35. Pied Flycatcher, May.

36. Nightjar, about the middle of May. 


\section{WHERE OUR SUMMER MIGRANTS SPEND THE WINTER}

I. Spotted Crake, Africa and India.

2. Ring Ouzel, Northern and Central Africa and Asia Minor.

3. Wheatear, Western and Northern Africa to Persia and Northern India.

4. Stone Curlew, Temperate Europe, Northern Africa, and SouthWestern Asia.

5. Chiff Chaff, shores of the Mediterranean.

6. Yellow Wagtail, Africa.

7. Sand Martin, India and Africa.

8. Swallow, Africa and India.

9. House Martin, Africa.

I0. Redstart, Northern Africa.

II. Grasshopper Warbler, Northern Africa and Southern Europe.

12. Whinchat, Northern Africa.

13. Blackcap, Northern Africa and Southern Europe.

14. Nightingale, Africa.

15. Hobby Falcon, Africa and India.

16. Wryneck, China and Northern Africa.

17. Cuckoo, Central Africa and Southern India.

18. Tree Pipit, Africa, Persia, and India.

19. Common Sandpiper, Africa.

20. Lesser Whitethroat, Africa.

21. Greater Whitethroat, Southern Africa.

22. Willow Warbler, Africa and Persia.

23. Kentish Plover, Africa, India, and Southern China.

24. Corncrake, Algeria, Egypt, Asia Minor, and Palestine.

25. Red-Backed Shrike, Africa.

26. Sedge Warbler, Northern Africa and Asia Minor.

27. Garden Warbler, Africa.

28. Reed Warbler, Africa.

29. Wood Warbler, Africa.

30. Turtle Dove, Northern Africa, Egypt, and Nubia.

31. Quail, Egypt and Northern Africa.

32. Swift, Africa.

33. Spotted Flycatcher, Africa.

34. Pied Flycatcher, Africa.

35. Nightjar, India and Africa.

36. Marsh Warbler, Africa. 


\section{LIST OF THE I78 SPECIES OF BIRDS, ARRANGED IN SCIENTIFIC ORDER}

\section{ORDER PASSERES}

Mistle Thrush (Turdus viscivorus)

Song Thrush (Turdus musicus)

Blackbird (Turdus merula)

Ring Ouzel (Turdus torqualus)

Wheatear (Saxicola ananthe)

Whinchat (Pratincola rubetra)

Stonechat (Pratincola rubicola)

Redstart (Ruticilla phonicurus)

Redbreast (Erithacus rubecula)

Nightingale (Daulias luscinia)

Greater Whitethroat (Sylvia cinerea)

Lesser Whitethroat (Sylvia curruca)

Blackcap (Sylvia atricapilla)

Garden Warbler (Sylvia hortensis)

Dartford Warbler (Melizophilus undatus)

Golden-Crested Wren (Regulus cristatus)

Chiff Chaff (Phylloscopus rufus)

Willow Warbler(Phylloscopus trochilus)

Wood Warbler (Phylloscopus sibilatrix)

Reed Warbler (Acrocephalus streperus)

Marsh Warbler (Acrocephalus palustris)

Sedge Warbler (Acrocephalus phrag. mitis)

Grasshopper Warbler (Locustella navia)

Hedge Sparrow (Accentor modularis)

Dipper (Cinclus aquaticus)

Bearded Titmouse (Panurus biamicus)

Long-Tailed Titmouse (Acredula caudata)

(ireat Titmouse (Parus major)

Coal Titmouse (Parus britannicus)

Marsh Titmouse (Parus palustris)

Blue Titmouse (Parus carulcus)

Crested Titmouse (I'arus cristalus)

Nuthatch (Sitta casia)
Brown Wren (Troglodytes parvulus)

Pied Wagtail (Motacilla lugubris)

Grey Wagtail (Motacilla melanope)

Yellow Wagtail (Motacilla rayii)

Meadow Pipit (Anthus pratensis)

Tree Pipit (Anthus trivialis)

Rock Pipit (Anthus obscurus)

Red-Backed Shrike (Lanius collurio)

Spotted Flycatcher (Muscicapa grisola)

Pied Flycatcher (.Muscicapa atricapilla)

Swallow (Hirundo rustica)

House Martin (Chelidon urbica)

Sand Martin (Cotile riparia)

Tree Creeper (Certhia familiaris)

Goldfinch (Carduelis elegans)

Siskin (Chrysometris spinus)

Greenfinch (Ligurinus chloris)

Hawfinch (Coccothraustes vulgaris)

House Sparrow (Passer domesticus)

Tree Sparrow (Passer montanus)

Chaffinch (Fringilla coelebs)

Linnet (Linota cannabina)

Lesser Redpoll (Linota rufescens)

Twite (Linota flavirostris)

Bullfinch (Pyrrhula europaa)

Crossbill (Loxia curvirostra)

Corn Bunting (Emberiza miliaria)

Yellow Bunting (Emberiza citrinella)

Cirl Bunting (Emberiza cirlus)

lieed Bunting (Emberiza schaniclus)

Snow Bunting (Plectrophanes nivalis)

Starling (Sturnus vulgaris)

Chough (Pyrrhocorax graculus)

Jay (Garrulus glandarius)

Magpie (Pica rustica)

Jackdaw (Corvus monedula)

Carrion Crow (Corvus corone)

Hooded Crow (Corvus cornix)

Rook (Corvus frugilegus) 


\section{LIST OF BIRDS IN SCIENTIFIC ORDER II}

Raven (Corvus corax)

Skylark (Alauda arvensis)

Woodlark (Alauda arborea)

\section{ORDER PICARIE}

Swift (Cypselus apus)

Nightjar (Caprimulgus europaus)

Great Spotted Woodpecker (Dendrocopus major)

Lesser Spotted Woodpecker (Dendrocopus minor)

Green Woodpecker (Gecinus viridis)

Wryneck (I $\ddot{y} n x$ torquilla)

Kingfisher (Alcedo ispida)

Cuckoo (Cuculus canorus)

\section{ORDER STRIGES}

Barn Owl (Strix flammea)

Long-Eared Owl (Asio otus)

Little Owl (Athene noctua)

Short-Eared Owl (Asio brachyotus)

Tawny Owl (Syrnium aluco)

\section{ORDER ACCIPITRES}

Marsh Harrier (Circus aruginosus)

Hen Harrier (Circus cyaneus)

Montagu's Harrier (Circus cineraceus)

Common Buzzard (Buteo vulgaris)

Golden Eagle (Aquila chrysaētus)

White-Tailed Eagle (Haliaètus albicilla)

Sparrow Hawk (Accipiter nisus)

Kite (Milvus ictinus)

Peregrine Falcon (Falco peregrinus)

Hobby Falcon (Falco subbuteo)

Merlin (Falco cesalon)

Kestrel (Tinnunculus alaudarius)

Osprey (Pandion haliaëtus)

\section{ORDER STEGANOPODES}

Cormorant (Phalacrocorax carbo)

Shag (Phalacrocorax graculus)

Gannet (Sula bassana)

ORDER HERODIONES

Heron (Ardea cinerea)

\section{ORDER ANSERES}

Grey Lag Goose (Anser cinereus)

Mute Swan (Cygnus olor)

Common Sheldrake (Tadorna cornuta)

Wigeon (Mareca penelope)

Wild Duck (Anas boscas)

Gadwall (Chaulelasmus streperus)

Garganey (Querquedula circia)

Common Teal (Qucrquedula crecca)

Shoveler (Spatula clypeata)

Tufted Duck (Fuligula cristata)

Pochard (Fuligula ferina)

Eider Duck (Somateria mollissima)

Common Scoter (Edemia nigra)

Goosander (Mergus merganser)

Red-Breasted Merganser (Mergus serrator)

\section{ORDER COLUMBE}

Ring Dove (Columba palumbus)

Stock Dove (Columba œnas)

Rock Dove (Columba livia)

Turtle Dove (Turtur communis)

\section{ORDER GALLINE}

Pheasant (Phasianus colchicus)

Red-Legged Partridge (Caccabis rufa)

Common Partridge (Perdix cinerea)

Quail (Coturnix communis)

Ptarmigan (Lagopus mutus)

Red Grouse (Lagopus scoticus)

Black Grouse (Tetrao tetrix)

Capercaillie (Tetrao urogallus)

\section{ORDER FULICARIE}

Water Rail (Rallus aquaticus)

Spotted Crake (Porzana maruetta)

Corncrake (Crex pratensis)

Moorhen (Gallimula chloropus)

Coot (Fulica atrao)

\section{ORDER LIMICOL $\mathbb{E}$}

Stone Curlew (Edicnemus scolopax) Golden Plover (Charadrius pluvialis) Kentish Plover (Egialitis cantiana) Ringed Plover (Egialitis hiaticula) 
Dotterel (Endromias morinellus)

Lapwing (Vanellus vulgaris)

Oystercatcher (Hamatopus ostralegus)

Red-Necked Phalarope (Phalaropus hyperboreus)

Woodcock (Scolopax rusticula)

Common Snipe (Gallinago calestis)

Dunlin (Tringa alpina)

Common Sandpiper (Tringoīdes hypoleucus)

Redshank (Totanus calidris)

Greenshank (Totanus canescens)

Whimbrel (Numenius phaopus)

Curlew (Numenius arquata)

\section{ORDER GAVIA}

Arctic Tern (Sterna macrura)

Common Tern (Sterna fluviatilis)

Roseate Tern (Sterna dougalli)

Lesser Tern (Sterna minuta)

Sandwich Tern (Sterna cantiaca)

Kittiwake Gull (Rissa tridactyla)

Herring Gull (Larus argentatus)

Lesser Black - Backed Gull (I.arus fuscus)

Common Gull (Larus canus)

Great Black-Backed Gull (Larus marinus)
Black-Headed Gull (Larus ridibundus) Common Skua (Stercorarius catarrhactes)

Richardson's Skua (Stercorarius crepidatus)

\section{ORDER TUBINARES}

Stormy Petrel (Procellaria pelagica)

Fork-Tailed Petrel (Procellaria leucorrhoa)

Manx Shearwater (Pufinus anglorum) Fulmar Petrel (Fulmarus glacialis)

\section{ORDER PYGOPODES}

Black-Throated Diver (Colymbus arcticus)

Red-Throated Diver (Colymbus septentrionalis)

Great Crested Grebe (Podiceps cristatus)

Little Grebe (Tachybaptes fluviatilis)

Razorbill (Alca torda)

Common Guillemot (Lomvia troile)

Black Guillemot (Uria grylle)

Puffin (Fratercula arctica)

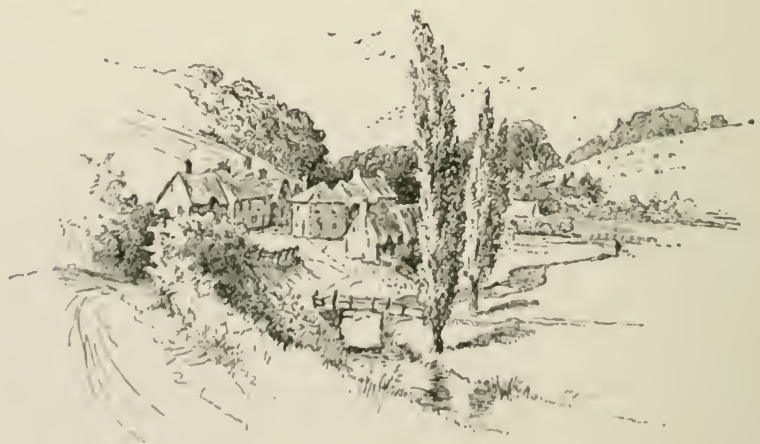




\section{LIST OF ILLUSTRATIONS \\ COLOURED PLATES AND HALF-TONES}

Wheatear, Whinchat, and Eggs .

Frontispiece

Cirl Bunting, Reed Bunting, and Eggs . . . facing page I6

Female Blackbird on Nest. Young Blackbirds in Nest. ", I7

Eggs of British Birds . . . . . . " " 34

Meadow Pipit's Nest containing Cuckoo's Egg. Meadow

Pipit feeding young Cuckoo . . . . . . . 35

Turtle Dove. Young Turtle Doves . . . . . . 50

Young Kestrels. Lapwing at Nest . . . . . . 5 I

Tawny Owl. Hobby Falcon . . . . . . " 70

Young Kingfishers. Moorhen on Nest . . . . . 7 I

Common Partridge on Nest. Also Nest and Eggs . . $\quad 78$

Golden Plover. Redshank . . . . . . " 79

Stonechat. Great Tit . . . . . . . . 98

Nest and Eggs of Stonechat. Mute Swan . . . $\quad$, 99

Nest, Eggs, and Young of Greater Whitethroat . . . . II4

Green and Lesser Spotted Woodpeckers, and Eggs . . II5

\section{ILLUSTRATIONS IN THE TEXT}

FIG.

I. Blackcap • . . . . . . . . . 18

2. Yellow Bunting . . . . . . . . . 22

3. Head and Foot of Common Buzzard . . . . . 23

4. Chiff Chaff . . . . . . . . . . 25

5. Coot . . . . . . . . . . . . . 26

6. Cormorant . . . . . . . . . . . 27

7. Head of Corncrake . . . . . . . . . 28

8. Tree Creeper . . . . . . . . . . . 29

9. Head and Foot of Curlew . . . . . . . . . 33

Iо. Dunlin . . . . . . . . . . . 4 II

II. Pied Flycatcher . $\quad$. $\quad$. $\quad$. . . . . 43

12. Head of Great Crested Grebe . . . . . . . 48

13. Head and Foot of Little Grebe . . . . . . . 49

14. Head of Common Guillemot . . . . . . $\quad$. 52

15. Head of Hawfinch . . . . . . . . . 58

16. Head of Heron . $\quad$. $\quad$. $\quad$. $\quad$. $\quad$. 59 
FIG.

PAGE

17. Head of Jackdaw

I8. Head of Jay

I9. Kiestrel

20. Head of Lapwing

21. House Martin

22. Young Moorhen .

23. Nightingale

24. Head and Foot of Nightjar

25. Nuthatch

26. Head of Oystercatcher .

27. Head of Red-Legged Partridge

2S. Meadow Pipit

29. Head and Foot of Tree Pipit

30. Head of Puffin

31. Head of Razorbill

32. Lesser Redpoll .

33. Head of Rook

34. Head of Common Sandpiper .

35. Head and Foot of Red-Backed Shrike

36. Head and Foot of Common Snipe .

37. Starling

38. Swallow

39. Swift .

40. Long-Tailed Tit

4I. Grey Wagtail

42. Pied Wagtail

43. Garden WVarbler .

44. Sedge IVarbler

45. Willow Warbler

46. Whinchat .

47. Greater Whitethroat

48. Head of Woodcock

49. Head and Tongue of Green Woodpecker

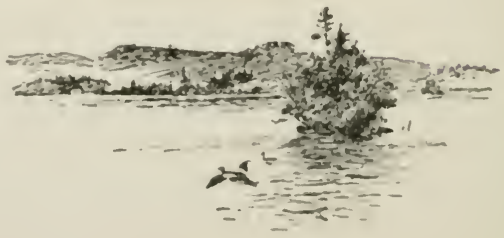




\section{GL OSSAR Y}

Axillaries.-The inner feathers under the wing, or armpit.

Cere.-The soft skin which covers the base of the upper mandible.

Culmen.-The median lengthwise ridge of the upper mandible.

Dorsal.-Of, or pertaining to, the back.

Flanks.-The borders of the lower breast.

Iris.-The coloured circle round the pupil of the eye.

Lores.-The space between the eye and the beak.

Mandibles.-The upper and lower halves of the beak.

Metatarsus.-That portion of the foot which reaches from the ankle-joint to the base of the toes.

Moustaches.-Feathers on head which give the bird a moustache-like adornment.

Nape.-The back upper part of the neck.

Occiput.-The hinder part of the head.

Orbit.-The bony cavity in which the eyeball rests.

Primaries.-The larger quill-feathers of the wing.

Retrices.-The tail-feathers.

Scapulars.-The shoulder-feathers between the wing and the back.

Secondaries.-The feathers of the wing which succeed the primaries near the wrist-joint.

Shank.-That portion of the leg between the ankle and the thigh.

Speculum.-The patch of bright feathers on the secondaries.

Striated.-Streaked with parallel lines.

Tarsus.-That portion of the leg between the ankle and toes.

Transverse.-In a cross direction.

Under tail-coverts. - The feathers on the under side of the tail.

Upper tail-coverts. - The feathers on the upper side of the base of the back.

Ventral.-Belonging to the belly.

Vermiculated.-Feathers inlaid with a worm-like pattern.

Wing-coverts. - The feathers on the shoulder of the wing. 

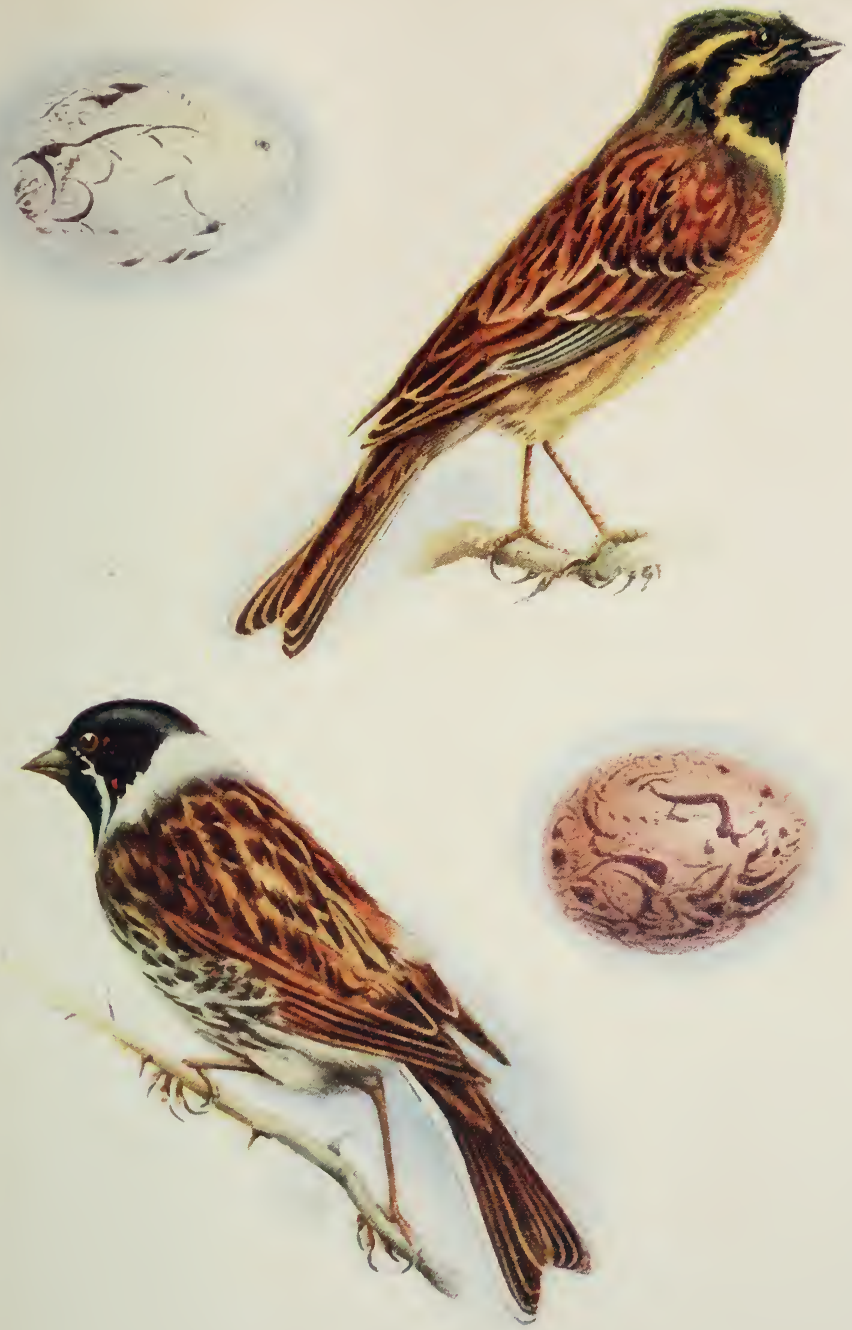

('iri, Bunting (above), Reed Bunting (below). Also figris of Both sperifs. 


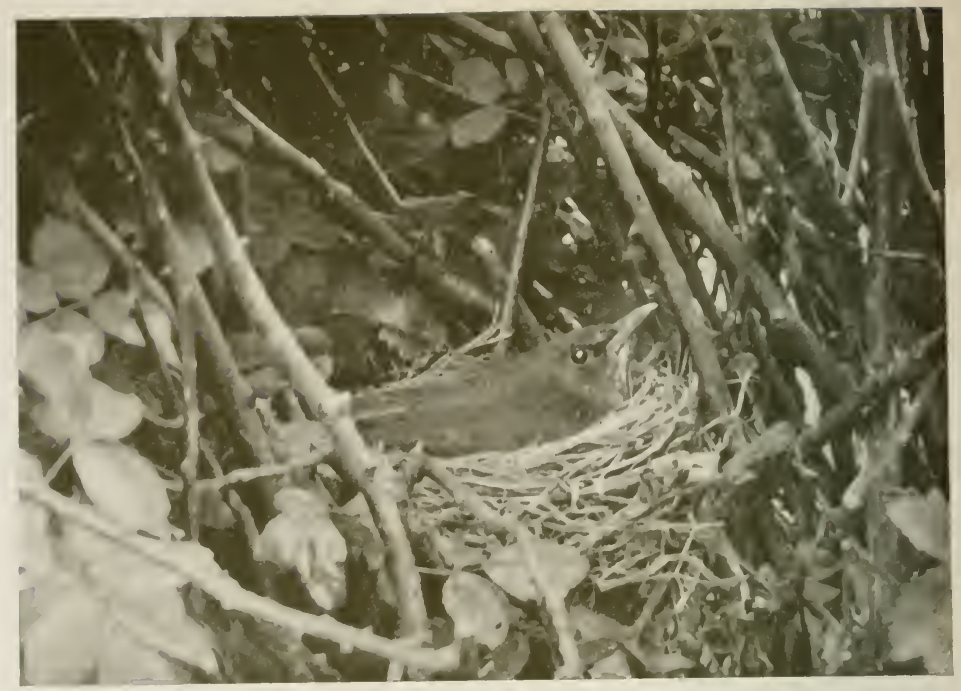

Female Blackirird on Nest.

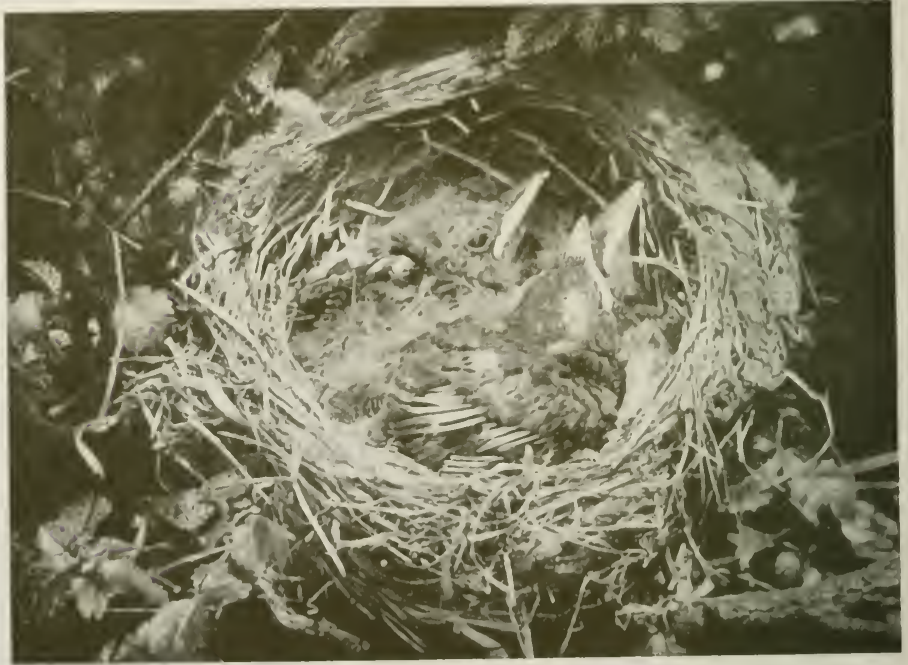

YOUNG BLACKBIRDS IN NIEST. 


\section{BRITISH NESTING BIRDS}

\section{BLACKBIRD (Turdus merula)}

Local Names.-Blackie, Black Ousel, Black Thrush, Garden Ousel, Golden Bill, Merle, Oossel, Oussel.

Haunt.-Woods, copses, plantations, hedgerows, gardens, etc.

Nesting Period.-March to September.

Site of Nest.-Bushes, trees, shrubs, hedges, etc.

Materials Used.-Coarse grass, lined with finer portions; a very firm structure, strongly woven together with mud and cow dung. Eggs.-Generally Five, but sometimes as many as Six. Dusky bluish-green, covered with black or brown spots or patches. Food.-Insects, snails, earthworms, and fruit. Voice.-The song of the Blackbird is both mellow and measured. The notes are quite unlike those of the Thrush, which are short, quick, and extremely varied. There is little variation in the song of the Merle. Sometimes, however, the notes are light and buoyant, at others solemn and vesper-like. The metallic alarm note may be likened to " chink, chink."

Chief Features.-A restless species; does not flock in Winter like many of its relatives; flies low. An early songster, commencing in February. Belongs to the Thrush family.

Plumage.-Male bird jet black with an orange beak, female much lighter, and has a dusky beak. Length.-Ten inches. The young are spotted, and may be mistaken for a dark variety of the Song Thrush.

\section{BLACKCAP (Sylvia atricapilla)}

Local Names.-Blackcap Warbler, Blackie Topper, Fauvette, Guernsey Nightingale, Haychat, Hay Jack, Jack Saw, Mock Nightingale, Nettle Creeper, Nettle Monger.

Haunt.-Woods, copses, large gardens, and hedgerows. Nesting Period.-May and June.

Site of Nest.-A bramble or wild rose bush, also a low hedge.

Materials Used.-Fine and also coarse grasses, fibrous roots, with a lining of fine roots and hair. The webs of spiders are used on occasions for binding nest together. A frail but neat nest.

Eggs._Four to Six. Ground colour yellow, brownish, or reddish, blotched, spotted, and streaked with dark brown. 
Food.-Insects and their larvæ, berries, and soft fruits.

Voice. - The notes are uttered in one continuous bubbling strain, and are very beautiful. They are flute-like and musical, but the song is often very low and subdued. Male bird is

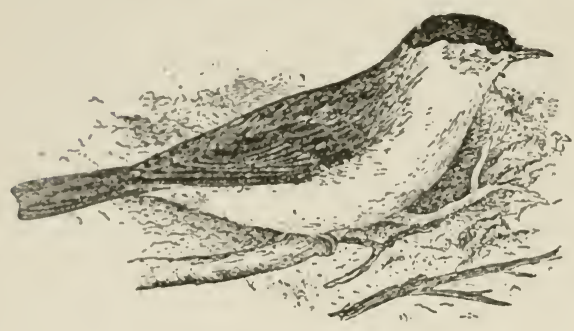

Fig. ז. Blackcap. very agitated when singing, raises crest feathers when thus engaged, with a tremulous motion of wings and tail.

Chief Features.-The black and brown heads of male and female respectively are sure methods of identification. A Summer visitor only. The bird returns to the same haunt each season.

By no means common, but is often overlooked because of its shy, skulking habits. Does a great deal of good by reason of its insectivorous diet.

Plumage. - The black cap is the distinguishing feature of the male, the remainder of the plumage being generally ashy-grey and bluish-grey. The female has the top of the head reddish-brown, whilst the other parts are somewhat browner than those of the male bird. Length.-Five and a half inches.

\section{BULLFINCH (Pyrrhula europaa)}

Local Names.-Alp, Blackcap, Budpricker, Bully, Blood-Ulf, CoalHood, Coally-Hood, Hoop, Hope, Mivope, Monk, Nope, Olf, Olph, Pope, Red Hoop, Ting Hoop, Toney Hoop, Tony. Haunt.-Woods, commons, thickets, hedgerows, and gardens. Nesting Period.-May, June, and July.

Site of Nest.-Bramble and other bushes, shrubs, hedgerows, etc. Materials Used.-Small twigs and fibrous roots, with a little black hair for a lining. A very small nest for so large a bird.

Eggs.-Four or Five. Greenish-blue, spotted in the form of a ring, and sometimes blotched, with black or dark brown, mostly at the larger end.

Food.-In Summer, insects and their larvæ; in Autumn and Winter, various seeds of weeds, hips, haws, berries, and buds.

Voice.-In a wild state a low, plaintive note is uttered, as well as a subdued song. When taken from nest the young may be taught to pipe beautifully, and such birds command a high price and a ready salc. 


\section{CIRL AND CORN BUNTINGS}

Chief Features.-One of the few British birds which pairs for life. May be easily distinguished by shape, size, and prominent white rump when flying. Flight is heavy and hesitating.

Plumage.-The male has a rosy-red breast, grey slate-coloured back, white rump, and blue-black head, wings, and tail. The female is much less gaudy, the whole being duller, and the breast is warmish-brown and the upper parts brownish-grey. Length.Six and a quarter inches.

\section{BUNTING, CIRL (Emberiza cirlus)}

Local Names.-Black-Throated Yellow Hammer, French Yellow Hammer.

Haunt.-Lanes, hedgerows, commons, stackyards, etc.

Nesting Period.-May, June, and July.

Site of Nest.-A low bush, or on the ground. A furze bush is a. favourite site.

Materials Used.-Dried stalks, moss, roots, with a lining of hair and roots. Sometimes no hair is used.

Eggs.-Four or Five. Dull white or bluish-grey in ground colour, streaked, blotched, and spotted with dark brown, with patches of ash-grey. More strongly marked and of a more bluish tinge than those of the Yellow Bunting.

Food.-Insects and seeds in Summer; seeds and grain in Winter.

Voice.-The song is much like the well-known simple refrain of the Yellow Bunting, but the two concluding notes are wanting. This is a distinguishing characteristic.

Chief Features.-Appears to be a more recluse species than its betterknown relative, and to haunt tall trees. A restless bird, and requires careful watching before identity is certain. The black streaks and black throat at once distinguish the male bird.

Plımage.-Chestnut on the upper parts, with streaks of black. The head and back of neck are olive, streaked in the same manner as last mentioned; greenish-olive rump, with dusky streaks; stripe over eye and one underneath, yellow; black throat and a little further on a collar of pale sulphur-colour; breast olive-grey; belly pale dull yellow. Female lacks the black and yellow face markings. Length.-Six and a half inches.

\section{BUNTING, CORN (Emberiza miliaria)}

Local Names.-Bunting, Bunting Lark, Bush Lark, Clod Bird, Common Bunting, Ebb, Horse Lark, Land Bunting, Scribbling Lark, Stocking Weaver, Stone Chacker, Thistle Cock, Whisker Bird, Writing Lark. 
Haunt.-Commons, downs, large fields, lanes, tall hedges, etc. Nesting Period.-May and June.

Site of Nest.-Low down in a hedge or bush, or on the ground among coarse grass.

Materials Used.-Dried grass and straw outside, lined with roots, fine grass, and sometimes hair.

Eggs.-Three to Six. Four is the usual clutch. A larger egg than any other British Bunting, and not so pointed as some of the others. Dull white in ground colour, blotched and streaked with liver-colour, inclining to black.

Food.-Insects, seeds, and grain.

Voice.-A wheezy, persistent little song, very typical of the haunts frequented. Once or twice heard not easily forgotten. The notes are rusty and somewhat harsh.

Chief Features.-Very locally distributed, but where it does occur it is common. A solitary species. The large size and plain colouration, as well as the wheezy song, all aid in identification. Plumage.-Upper parts yellowish-brown with dusky spots; markings underneath are yellowish-white, streaked and spotted with dusky. Length.-Seven and a half inches.

\section{BUNTING, REED (Emberiza schœniclus)}

Local Names.-Blackbonnet, Blackcap, Black-Headed Bunting, Chinck, Coalhead, Mountain Sparrow, Passerine Bunting, Reed Sparrow, Ring Bird, Ring Bunting, Ring Fowl, Toadsnatcher, Water Sparrow.

Haunt.-Osier plantations, willow thickets, and marshy places. Nesting Period.-April to July.

Site of Nest.-Usually, but not invariably, low down among tangled grasses in a marshy place. Sometimes among osier stems. Always near water.

Materials Used.--Reed stems or leaves, dry grasses, and moss, lined with fine grass, reed flowers, and hair. A rather deep nest.

Eggs._-Four or Five. Ashy-grey in ground colour, with prominent jet-black markings. More pointed than the eggs of its congeners, and markings fewer but more distinct.

Food.-Insects, seeds, and grain.

Voice.-A harsh kind of chatter, sometimes chirpy and varied, reminding one of a medley of notes uttered by different birds. Not nearly so characteristic in this respect, however, as the song of the Sedge Warbler.

Chief Features.-This Bunting is of a lively disposition, and thrusts itself, as it were, upon the observer. The black head of male 


\section{REED AND SNOW BUNTINGS}

is very distinct, but it is wrong to call this species Black-Headed Bunting, as the last named has only been obtained in the British Isles on one solitary occasion.

Plumage. - The male has the head and throat black, with a speckling of light brown in Winter; sides of neck and nape white, as also is a line which extends to the base of the beak. The upper portions are dusky and reddish-brown, and the under parts are white, streaked with dusky on the flanks. The female has a reddish-brown head with dusky spots, the white neck is not so conspicuous as in the male, and the underneath is reddishwhite with dusky spots. Length.-Six inches.

\section{BUNTING, SNOW (Plectrophanes nivalis)}

Local Names.-Brambling, Great Pied Mountain Finch, Greater Brambling, Lesser Mountain Finch, Little Mountain Finch, Mountain Bunting, Oat Fowl, Pied Mountain Finch, Snowflake, Snowfleck, Snow-Fowl, Snow Hammer, Tawny Bunting.
Haunt.-Mountains and moors in the North; many flocks come
South in Winter. South in Winter. Nesting Period.-May, June, or July. Site of Nest.-Crevices in rocks or mountains, among stones, etc. Materials Used.-Dry grass, moss, and roots, lined with feathers,
hair, or down.

Eggs.-Five, Six, or more. Pale blue or greyish-white, spotted and blotched with reddish-brown, with underlying markings
of pale grey and pale brown. Food.-The larvæ of gnats, as well as seeds of grass and weeds. Voice.-A low, sweet warble. The song is said to be not unlike that of the Shore Lark.

Chief Features.-A bird of lonely solitudes. Undergoes a change of plumage in Winter (see below). The white character of plumage accounts for several of the local names. When in with others of its family. Plumage. - The head, neck, and a part of the wings and under portions are white, whilst the upper parts are black, with a tinge of red somewhat scattered. During Winter the white head and black back are mixed with reddish-brown. The female has the white on the head and the upper parts mottled with dusky, and the colours in this latter sex are not of such a pure character. Length.-Six inches and three-quarters. 


\section{BUNTING, YELLOW (Emberiza citrinella)}

Local Names.-Blacksmith, Blakeling, Cheeser, Devil's Bird, Gladdy, Golden Gladdy, Goldie, Goldspink, Gooler, Gool Finch, Scobby, Scotch Canary, Scribbling Lark, Shell Apple, Shelly, Shilfa, Skelly, Skite, Writing Lark, Writing Master, Yeldrin, Yeldrock, Yellie, Yellow Ammer or Hammer, Yellow Yeldring, Yellow Yeldrock, Yellow Yeorling, Yellow Yite, Yellow Yoldrin, Yellow Yowley, Yoit, Yoldring, Yolkring.

Haunt.-Hedgerows, lanes, and commons; visits stackyards.

Nesting Period.-April to August.

Site of Nest.-In a bush or hedgerow, usually low down. Often in a bank, sometimes right on the ground.

Materials Used.-Coarse and fine grasses, with a little moss, lined with roots and hair. The nest varies in size, but is generally fairly deep and substantial. Eggs.-Three, although most ornithologists seem to favour Four or Five. This is contrary to my own experience. Dirty white, with an ashy tinge, streaked and spotted with

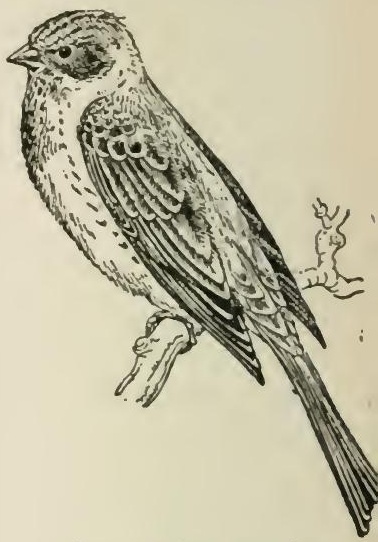

Fig. 2. Yellow Bunting.

dark purplish-brown. The irregular lines run into one another. Food.-Insects in Summer, seeds and grain in Winter.

Voice.-A characteristic and harsh call-note, and a curious little song consisting of several notes persistently uttered. These have been aptly compared to the words, "A little bit of bread, and no cheese," the last word being long drawn out.

Chief Features.-The male is one of the most handsome British birds, and is far better known as Yellow Hammer. The curious markings on the eggs account for the name of Scribbling Lark. The bird often mounts the topmost twigs of a bush and there sings its curious little song.

Plumage. - The rich bright colours of the male are made up ofhead, neck, and under parts golden-yellow, with a sprinkling of dark olive; black back, interspersed with reddish-grey; yellow breast, spotted with red. In the female the yellow is not of so bright a character, and she is spotted with dull reddishbrown. Length.-Six and a quarter inches. 


\section{BUZZARD, COMMON (Buteo vulgaris)}

Local Names.-Blood Hawk, Mouse Buzzard, Puttock. Haunt.-Mountains, cliffs, moors, large woods, and other places. Nesting Period.-May.

Site of Nest.-Cliffs, trees, etc.

Materials Used.-Large and small sticks, lined with dry grass, leaves, wool, etc. Sometimes heather is used. A large nest. The deserted nest of a Crow is often appropriated.

Eggs.-Three. Greenish-white, slightly marked with pale brown.

Food.-Small birds, hares, rabbits, rats, and reptiles.

Voice.-A plaintive and monotonous call: "pe-e-i-oo," or "a-e-i-o-u."

Chief Features.-A handsome bird of prey, and a magnificent species when seen on wing. Commoner than most people imagine.

Plumage.-The upper parts of the head

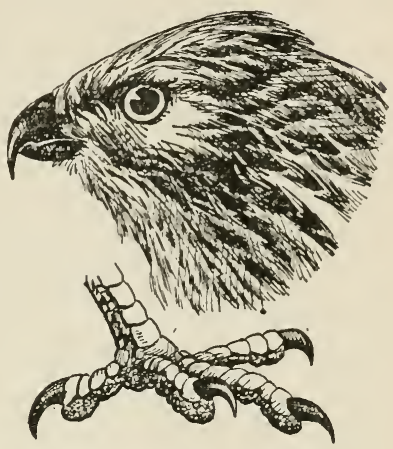

Fig. 3. Head and Foot of Common Buzzard. and neck are dark brown, with a mottling of brown of a darker shade; lead-coloured beak; cere. irides, and feet yellow. Length. -Male about twenty inches; the female exceeds her mate by two inches.

\section{CAPERCAILLIE (Tetrao urogallus)}

Local Names.-Capercailzie, Caperkally, Cock of the Mountain or Wood, Great Grouse, Mountain Cock, Wood Grouse. Haunt.-Moors and forests in Scotland.

Nesting Period.-End of May and beginning of June.

Site of Nest.-In a forest among heather or bilberries.

Materials Used.-A depression in the ground, and this, with the excep-

tion perhaps of a few blades of grass, constitutes the " nest."

Eggs.-Six to Twelve. Pale reddish-yellow-brown, well spotted all

over with two shades of darker orange-brown.

Food.-Buds and shoots of plants and trees, also berries.

Voice.-A strong double cry, frequently repeated.

Chief Features.- This is our largest British Game bird, and has had a curious history in Great Britain, as it became extinct about the middle of the eighteenth century, but since its reintroduction some eighty or ninety years later has flourished exceedingly. Plumage.-For the description of this bird I quote from Hudson's 
British Birds: "Feathers of the throat elongated, black; head and neck dusky; eyes with a bare red skin above and a white spot below; wings brown speckled with black; breast lustrous green; belly black with white spots; rump and flanks marked with undulating lines of black and ash colour; tail black with white spots; beak horn white. Female: A third smaller, barred and spotted with tawny-red, black and white; throat tawnyred; breast deep red; tail dark red with black bars, white at the tip." Length.-From thirty-three to thirty-six inches.

\section{CHAFFINCH (Fringilla cœlebs)}

Local Names.-Beech Finch, Boldie, Buck Finch, Chaffy, Charbob, Copper Finch, Dad Finch, Horse Finch, Horse-dung Finch, Pie Finch, Piet Lintie, Pink, Pink Pink, Scobly Buck Finch, Shilfa, Skclly, Spink, Spinx, Tink, Twinck, Wetbird, Whit Finch, White Finch, White Wing.

Haunt.-Woods, copses, lanes, fields, hedgerows, and gardens.

Nesting Period.-April to June.

Site of Nest.-Bushes, hedgerows, between the limbs of a tree, etc. Materials Used.-Moss, wool, hair, feathers, lichen, and roots. A most beautiful nest, small, compact, and symmetrical.

Eggs.-Four to Six. Ash-grey or blue-grey, with a wine-coloured tinge, spotted with dark brown and black.

Food.-Insects and their larvæ in Spring and Summer; seeds and beech-mast in Autumn and Winter.

Voice.-Alarm or call-note a shrill " pink, pink," uttered by both male and female. The latter also utters a weeping note. Male bird has a shrill, high-pitched song with a pleasing cadenza. Song rivalry in the Spring is very noticeable.

Chief Features. - The specific name of colebs indicates a bachelor, the males and females separating into distinct flocks in Winter. Male bird is one of the most handsome of our native Finches. An active, engaging bird at all times.

Plumage.-Black forehead; greyish-blue crown and nape; chestnut back and scapulars with a green tinge; green rump; chestnutred breast, which fades into white on the belly; black wings, with two bands of white; coverts of secondaries edged with yellow; black tail, the two central feathers ashy-grey, the two outer, on either side, black, with a white band of a broad and oblique character. The female is not clothed in such brilliant hues: the colours are duller, the colouring generally being ashygrey and olive-yellow, and the white bars are not so pure as those of the male bird. Length.-Six inches. 


\section{CHIFF CHAFF AND CHOUGH}

\section{CHIFF CHAFF (Phylloscopus rufus)}

Local Names.-Arbour Bird, Bank Bottle, Chip Chop, Choice and Cheap, Dark-Footed Pettychaps, Hay-bird, Least Willow Wren, Lesser Pettychaps, Linty White, Sally Picker, Short-Winged

Wood Wren, Smallest Willow Wren, Thummie.

Haunt.-Woods, copses, plantations, commons, and large gardens. Nesting Period.-April to June.

Site of Nest.-Banks, or base of a bush.

Materials Used. - An almost domed nest consisting of dry grass, moss, and leaves, profusely lined with feathers.

Eggs.-Six. A clear white, specked with dark purplish-red.

Food. - Insects and their larvæ.

Voice.-Two notes quickly uttered, from which the bird has obtained its name. When it has young it also emits a plaintive and monoto-

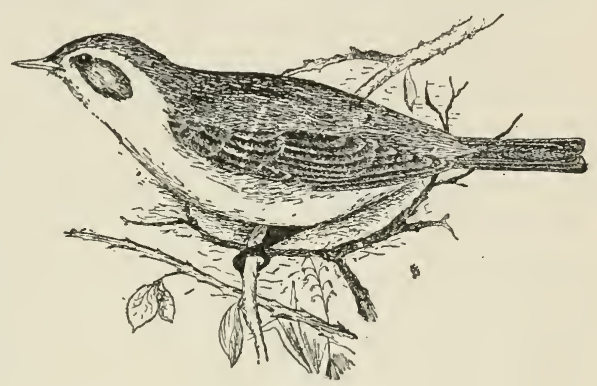

Fig. 4. Chiff Chaff. nous note which is very distracting, and when searching for food calls " chadic, chadic." Chief Features.-Although some of these birds are resident, it is mostly a Summer Migrant, arriving by the end of March. Haunts the tops of tall trees and searches incessantly for food. Will hawk for insects in the air after the manner of a Flycatcher. May be confused with the Willow Wren, but is not so yellow in colour, and has black legs.

Plumage.-The plumage above is olive-green with a tinge of yellow: a faint yellowish-white streak above the eye; light grey or stone-colour underneath; feathers on legs greyish-white. Length.-Four inches and three-quarters.

\section{CHOUGH (Pyrrhocorax graculus)}

Local Names.-Chank, Chank Daw, Cliff Daw, Cornish Chough, Cornish Daw, Cornish Kae, Gesner's Wood Crow, Hermit Crow, Killingcrew, Long-Billed Chough, Market-Jew Crow, RedLegged Crow, Red-Legged Jackdaw, Red-Shanks, Sea Crow. Haunt.-Near the sea; on cliffs, the seashore, etc. Nesting Period.-May. 
Site of Nest.-Crevices and holes in rocky sea cliffs and caves. Occasionally in holes in old ruins.

Materials Used.-Sticks, lined with roots, dry grass, wool, and hair. Eggs.-Four or Five. Yellowish-white, spotted with ash-grey and light brown.

Food.-Carrion, grubs, worms, berries, and grain.

Voice.-Chatters something like the Starling; also cries similar to the Jackdaw, but note is more ringing and musical.

Chief Features.-One of the most interesting members of the Crow family, the striking appearance making the Chough a most attractive species. It has largely decreased in England as a nesting bird.

Plumage.-Wholly black, with purple and green reflections; long red bcak, legs, and feet. Length.-Sixteen inches.

\section{COOT (Fulica atra)}

Local Names.-Bald Coot, Bald Duck, Bald-Headed Coot, Belpoot, Beltie.

Haunt.-Lakes and streams, especially where aquatic herbage is allowed to grow rank.

Nesting Period.-April onwards.

Site of Nest.--Always near water, and low down, either hidden among reeds, or floating on the surface on the inner margin of a patch of water plants.

Materials Used.-Reeds, sedges, rushes, and other herbage, lined with finer and drier portions of the same. Nest varies in size.

Eggs. - Seven to Twelve, or more. Dingy stone-colour, speckled and spotted with dark brown. A larger egg than that of the Moorhen, and not nearly so conspicuously marked.

Food.-Young shoots of aquatic plants, small fish, and worms.

Voice. - A clear-ringing, oft-repeated call, which has been written down

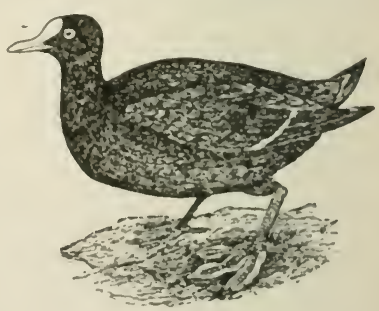

Fig. 5. Coot.

as " k-ō," " crew," or "kew." Not so harsh or metallic as the call of the Moorhen.

Chief Features. - Nay be at once distinguished by the white bald patch on forchead (see below). Often found in considerable numbers. It is stated to be always engaged in two things, either fighting or feeding.

Plumage.-May be distinguished from the Moorhen by its larger 
size; the latter is thirteen inches in length, and the Coot eighteen inches, but the chief characteristic is the white bald patch on the forehead, which has earned for the bird the title of BaldHeaded Coot. Underneath sooty black; above, slate-grey with a thin white bar across the wing; legs and feet dark green.

\section{CORMORANT (Phalacrocorax carbo)}

Local Names.-Cole Goose, Corvorant, Crested Cormorant, Gormer, Great Black Corvorant, Great Black and White Cormorant, Great Corvorant, Green Cormorant, Isle of Wight Parson, Norie, Parson, Scart, Sea Crow, Skart.

Haunt.-Sea cliffs and seashore, also large fresh-water lakes.

Nesting Period.-April to June.

Site of Nest.-Ledges of sea cliffs, tall trees or bushes when nesting inland. A social species, and nests in colonies.

Materials Used.-Seaweed, sticks, and dry grass. A large nest.

Eggs.-Four to Six. Whitish, this being caused by a chalky incrustation distributed over the whole shell. When this chalky surface is removed the egg is bluish-green.

Food.-Fish, including eels.

Voice.-A harsh scream; call-note, "kree," "kraw," or " krell."

Chief Features.-An expert fisherman. The bird will sit on a rock near the sea for hours at a stretch. Fond of preening its feathers and dozing. When a company are seen parading on the summit of a rock the effect is very curious. The young

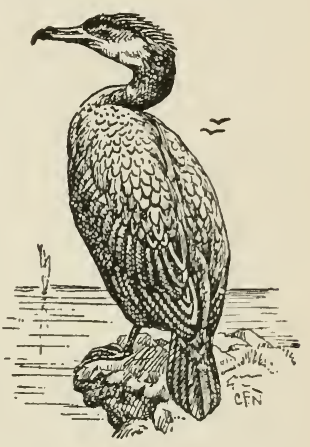

Fig. 6. Cormorant. birds are vociferous and hate being interfered with. A common species on many parts of our coast.

Plumage.-The upper head and neck are black, striated with hairlike white feathers, those on the occiput being elongated, and forming a crest in Spring; white throat; gular pouch yellow; mantle black and bronze-brown; all other parts are black with the exception of a white patch on the thigh, which is assumed early in the Springtime and lost during the Summer. The female is brighter than her mate, has a longer crest, and is larger. Length.-Three feet. 


\section{CORNCRAKE (Crex pratensis)}

Local Names.-Beaucrake, Corn-Cracker, Corn-Drake, Cracker, Crek, Daker Hen, Gallinule Crake, Gallinule Drake, Haycrake, Landrail, Meadow Crake.

Haunt.-Meadows, more especially those cultivated for hay.

Nesting Period.-End of May and June.

Site of Nest.-Among grasses in a meadow, or in a bank or hedge.

Materials Used. - Dry grass and leaves, lined with finer portions of the former. A shallow structure.

Eggs.-Seven to Twelve or more. Reddishwhite, blotched or spotted with reddishbrown and ash-grey.

Food.-Worms, beetles, slugs, snails, leeches, grass blades, and weed seeds.

Voice.-A harsh "kray, kray"; a deep, Fig. 7. Head of Corncrake. guttural note oft repeated. The bird often utters its cry whilst moving, and this results in a ventriloquial effect.

Chief Features.-A Summer Migrant, but whilst in Great Britain keeps almost exclusively to the ground, hidden among grasses, and is rarely seen. Has a skulking habit, and runs very swiftly with head carried well forward. A highly beneficial species, but not nearly so common in many districts as formerly.

Plumage.-It has patches of ash-grey above the eyes and on the cheeks; the upper parts are yellowish-brown with darker markings; quills and wing-coverts dark chestnut; white throat; greyish-buff breast; belly white towards the middle, the flanks marked or barred with brown and buff. Length.Eleven inches.

\section{CRAKE, SPOTTED (Porzana maruetta)}

Local Names.-Lacky-Mo, Lesser Spotted Water Rail, Skitty, Speckled Water Hen, Spotted Gallinule, Spotted Rail, Spotted

Water Hen, Spotted Water Rail, Water Crake, Water Rail, Vynkerrell.

Haunt.-Swampy localities.

Nesting Period.-May, or beginning of June.

Site of Nest.-Among aquatic herbage in a swamp or bog.

Materials Used.-Reeds, rushes, sedges, flags, and other water plants, with a lining of finer portions of same.

Eggs.-Eight to Ten. Olive-buff, with dark reddish-brown spots. Food.-Worms, insects, seeds, and vegetables. 
Voice.-A whistle-like "whëoo-whëoo" or " whuit-whuit," or a clear " whit" or " cruick."

Chief Features.-An uncommon British bird, very local in distribution. An early Summer Migrant, being the earliest to arrive during March. Spends the Winter in Africa and India.

Plumage.-Olive-brown, spotted with white; crown dark brown; face and neck dull grey; breast brown spotted with white; bill yellowish-green, the base orange-red; legs pale green. It is a very small bird, weighing only four ounces, and is nine inches in length.

\section{CREEPER, TREE (Certhia familiaris)}

Local Names.-Brown Woodpecker, Common Creeper, Creeper, Cuddy, Familiar Creeper, Tree Climber.

Haunt.-Woods, copses, parks, and large gardens where there are tall trees.

Nesting Period.-April onavards.

Site of Nest.-A hole or crevice in a tree, behind dislodged bark, in decayed trees, etc.

Materials Used.-Grass, pieces of bark, dead wood, and twigs, with a profuse lining of feathers, moss, and hair, the former especially.

Eggs.-Six to Nine. White, mostly spotted and speckled at larger end with brownish-red and greyish.

Food.-Insects and their larvæ.

Voice.-A short song is uttered, consisting of three or four shrill notes, as well as a high-pitched call-note. Mostly a silent bird. Chief Features.-A strictly arboreal species. An incessant insecthunter, and a remarkable

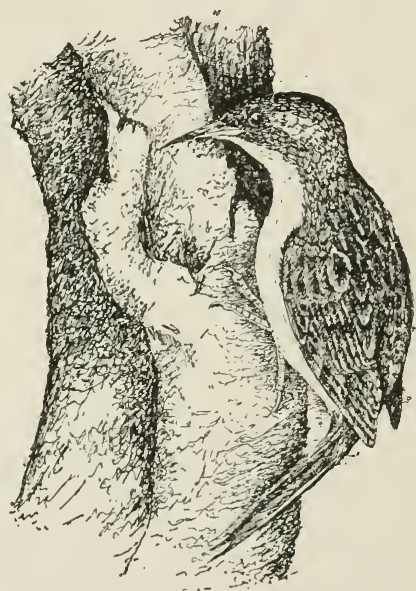

Fig. 8. Tree Creeper. acrobat in the tree-tops. The sharp-pointed tail, long beak, and strong feet are worthy of note. Must be carefully looked for, but is by no means uncommon.

Plumage.-Yellowish-brown, dark brown, and white above, with a pale streak over the eye. Breast and throat buff-white, dusky on the belly; brown wings with white tips and bars, together with brown and dull yellow. The tail feathers are reddishbrown, and are stiff and pointed. Length.-Five inches. 


\section{CROSSBILL (Loxia curvirostra)}

Local Names.-European Crossbill, European White-IVinged Crossbill, Shell Apple, Shield Apple.

Haunt.-Woods, forests, large gardens, and plantations.

Nesting Period.-February and Narch.

Site of Nest.-Trees, usually near the summit.

Materials Used.-Fir twigs and dry grass, lined with lichen, hair, fine grass, or wool.

Eggs._-Four or Five. White or greenish-white, with reddish-brown spots ond undermarkings of pale brown.

Food.-Seeds of the fir and fruit. Very fond of apple pips, hence one of its local names of Shell Apple.

Voice.-A loud, shrill call-note, and both sexes also utter a low warbling song.

Chief Features.-The curious crossed bill and handsome plumage of male bird. Nests in the North in the large pine forests, but a regular Southern visitor in Winter. A very sociable bird.

Plumage. - The tail feathers and those of the wings are brown; whilst the other parts are yellow, green, orange, and tile-red, which varies according to age and sex. In its wild state the full-grown male is red. Length.-Six and a half inches.

\section{CROW, CARRION (Corius corone)}

Local Names.-Black Crow, Black Neb, Bran, Bunting Crow, Cacl Crow, Corbie Crake, Corbie Crow, Crow, Doup, Flesh Crow, Gor Crow, Gore Crow, Hoody, Hoody Bran, Ket Crow, Midden Crow, Mussell Crow, Wood Crow.

Haunt.-Woods, rocky hillsides, and the seashore.

Nesting Period.-April and May.

Site of Nest.-Large trees in woods, or on rocky cliffs.

Materials Used.-I Large and small sticks, plastered with mud, clay, or cow dung, lined with moss, leaves, hair, wool, etc. .

Eggs.-Four or Five. Greenish, mottled, blotched, and spotted with light brown and greenish-ash.

Food.- Young birds, mammals, carrion of various kinds, grubs, worms, berries, grain, walnuts, and other fruit.

Voice.-A loud, harsh "caw," repeated not more than three times. A deeper note than that of the Rook.

Chief Features. - A much more solitary bird than the Rook. Does not nest in colonies, nor travel about in companies. A broaderlooking bird than its near relative, and the adult is feathered right down to the base of the beak. 
Plumage.-Black with green and violet reflections; the lower part of the beak is covered with bristly feathers; iris dark hazel. Length.-Nineteen inches.

\section{CROW, HOODED (Corvus cornix)}

Local Names.-Bunting Crow, Corbie Crake, Corbie Crow, Denchman, Denmark Crow, Dun Crow, Grey-Backed Crow, Grey Crow, Heedy Royston, Hoodie Crow, Kentish Crow, Kentishman, Market-Jew Crow, Norway Crow, Royston Crow, Saddle-

Backed Crow, Scale Crow, Scare Crow, Scremerston Crow.

Haunt.--Woods, rocky cliffs, and the seashore.

Nesting Period.-March to May.

Site of Nest.-Tall and low trees and bushes, and on cliffs.

Materials Used.-Same as Carrion Crow.

Eggs. - Four or Five. Very similar in both size and colour to those of the last named.

Food.- Similar to that of the Carrion Crow, together with shellfish and refuse. I have known it to attack a captive rabbit.

Voice.-Resembles that of the species last recorded.

Chief Features.-Not so solitary in disposition as the Carrion Crowof which species some ornithologists consider the Hooded to be only a variety-but to be distinguished by the partly grey plumage. Often to be seen on seashore feeding on animal refuse, and makes short work of any dead creatures there found. Plumage.-Head, throat, tail, and wings black; remainder of plumage ash or smoky-grey; iris brown. Length.-Nineteen and a half inches.

\section{CUCKOO (Cuculus canorus)}

Local Names.-Cog, Geck, Gowk, Grey Cuckoo, Tittling. Haunt.-Woods, copses, fields, lanes, large gardens, etc.

Nesting Period.-The egg is laid during May.

Site of Nest.-See under.

Materials Used.-None. As is well known, this bird does not build a nest of its own, but deposits its egg in the nest of another bird. The favourite foster parents appear to be the Hedge Sparrow, Robin, Pied Wagtail, Meadow Pipit (in Scotland), Chaffinch, and Sedge and Reed Warblers. The egg has been found in the nests of over one hundred different species.

Eggs.-It is uncertain how many eggs one female lays during a season. The egg varies in colour, and in some instances harmonises with those among which it is placed, at others it is quite distinct. Some varieties resemble those of the House 
and Tree Sparrows. Skylark, Meadow and Tree Pipits, etc. Even blue eggs have been discovered. There are usually small black specks on the egg, and in this way identification is made doubly sure. Pale greyish-green or reddish-grey is the general colour, more or less closely mottled, speckled, and spotted with darker shades.

Food.-Insects of various kinds, including butterflies and beetles.

Very fond of hairy larvæ, especially those of the Drinker Moth. Voice.-Both male and female utter the well-known plaintive double call. A kind of chattcring cry is also emitted when the bird is excited. The better-known notes are rarely heard after the end of June.

Chief Features.-The only British bird which does not rear its own young. Probably no species has caused so"much controversy, and it is still little understood. The young Cuckoo has the extraordinary habit of ejecting eggs or young birds from the nest in which it is born. Both, or either, are doomed, and when two young Cuckoos are hatched in the same nest the Philistines eject one another, and eventually the strongest alone survives. The young Cuckoo is blind during these operations, and when it receives its sight the desire to throw out anything ceases. A Summer Migrant, well distributed all over the country, the Cuckoo reaches us about mid-April, but makes an early departure in July or August, the young birds of the year following later. The clean-cut wings and quick, gliding flight are features worthy of note.

Plumage.-Upper parts bluish-ash, somewhat of a darker character on the wings, but lighter on neck and breast; whitish, with transverse dusky streaks, underneath; quills barred on inner webs with white oval spots; blackish tail feathers, tipped and spotted with white. The beak is dusky, with a yellow edging; orbits and inside of mouth yellow; iris and feet same colour. The young are ash-brown barred with reddish-brown; the tips of feathers are white, and there is a white spot on the back of the head. Length.-Thirteen and a half inches.

\section{CURLEW, COMMON (Numenius arquata)}

Local Names.-Calloo, Stock Whaap, Whaap, Whitterick.

Haunt.-Moors in Summer; mudbanks and saltings in Winter.

Nesting Period.-End of April and early in May.

Site of Nest.-Moors, heather-clad liills, etc.

Materials Used.-Dry grass, twigs of heather, leaves of rushes or sedges, etc. Nest is often placed in a depression in the ground, 2. and is usually well concealed by surrounding herbage. 
Eggs.-Four. Greenish-dun to olive-green, blotched with dark brown and dark shades of green.

Food.-Insects, worms, and perhaps tender shoots of plants in Summer; crustacea, marine worms and insects in Winter.

Voice.-A wild, weird cry.

Chief Features.-The bird has a long, curved beak and legs; it is a solitary species, inhabiting desolate places, where its weird note is in keeping with the surroundings. It is a larger bird than its near relative, the Whimbrel.

Plumage.-Reddish-ash mottled with dusky spots; almost white belly, with duskystreaks; white rumpand tail-coverts; tail - feathers barred

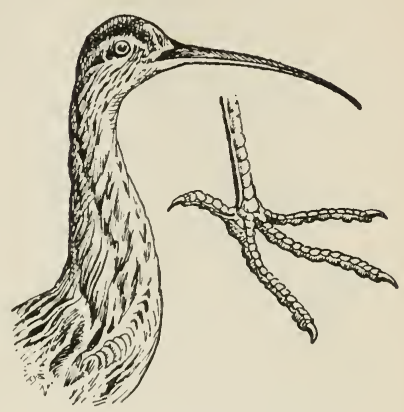

Fig. 9. Head and Foot of Curlew. with dark brown. Length.-The female is the larger of the two, measuring twenty-one to twenty-six inches.

\section{CURLEW, STONE (EEdicnemus scolopax)}

Local Names.-Common Thick-Knee, Great Plover, Land Curlew, Night Hawk, Norfolk Plover, Stone Plover, Thick-Knee, ThickKneed Bustard, Whistling Plover.

Haunt.-Waste commons, heaths, and downs.

Nesting Period.-May and June.

Site of Nest.-On the ground.

Materials Used.-Rarely any, the eggs being laid on the bare ground.

A few bents may sometimes be used.

Eggs.-Two. Stone-colour in various pale shades, fairly closely spotted, streaked, or marbled with dark brown.

Food.-Insects, worms, and snails.

Voice.-A wild, loud, clear-ringing cry uttered at night.

Chief Features.-Although some of these birds are said to be resident, the great majority are Migrants, reaching our shores from March to May. The bird has large eyes, long legs with thick knees, and can run very fast. It skulks when approached, and rarely takes to flight. It is largely protected by its surroundings. The young birds squat closely, and thus escape detection. Except in a few favoured localities this is a rare species. It is quite different in appearance to the Common Curlew.

Plumage.-The sexes are similar, the beak being black, yellowish at the base; irides, orbits, legs, and feet yellow; pale brown 
above; white tips on wing-coverts, forming two narrow bars; quill black; throat and stripe under the eye white; neck and breast buff with streaks of dark brown. Length.-Seventeen inches.

\section{DIPPER (Cinclus aquaticus)}

Local Names.-Benny Ducker, Brook Ousel, Common Dipper, Eso Cock, European Dipper Duck, Piet, River Pie, Sand Thrush, Water Blackibird, Water Colly, Water Crake, Water Crow, Water Ouzel, Water Pyet, Water Smith, IVater Thrush. Haunt.-Rivers and streams, secluded burns in Scotland. Nesting Period.-April to June.

Site of Nest.-In the fissure of a rock or overhanging bank, or between the stones of a bridge.

Materials Used.-A domed structure with a hole towards the base, consisting of moss outsicle and leaves within. The vegetation surrounding the nest makes the latter difficult to observe.

Eggs.-Five. White, pointed; size, I.O by .75 inch.

Food.-Aquatic insects and their larvæ, also small fresh-water snails and the fry of fishes.

Vcice.-A pretty utterance, which has been aptly described as " a merry little song coming out of a jocund little heart."

Chief Features.-Hudson calls this bird " a big black Wren with a silvery-white bib." The flight reminds one of the Kingfisher. The bird dives into the water, and often procures its food from the bed of the stream. It loves solitude, and its song, when heard for the first time, is very striking.

Plumage. - White throat and belly, the other parts black or blackishbrown. The colours of the female are more dingy than those of her mate. Length.-Six and a half inches.

\section{DIVER, BLACK-THROATED (Colymbus arcticus)}

Local Names.-Lesser Imber (female), Lumme, Northern Doucker, Speckled Loon.

Haunt.-Excepting when breeding, the Divers are Oceanic birds.

Frequents lochs, small islands, mountain waters, and seashore. Nesting Period.-May and June.

Site of Nest.- Near or on small islands, and other places.

Materials Used.-Various aquatic herbage, with a lining of grass.

Eggs.-Two. A handsome type of egg, rounded at both ends, not tapered like that of the Common Curlew. Some are dark brown tinged with olive, others are russet-jrown, spotted or blotched with black and dark brown. 
3
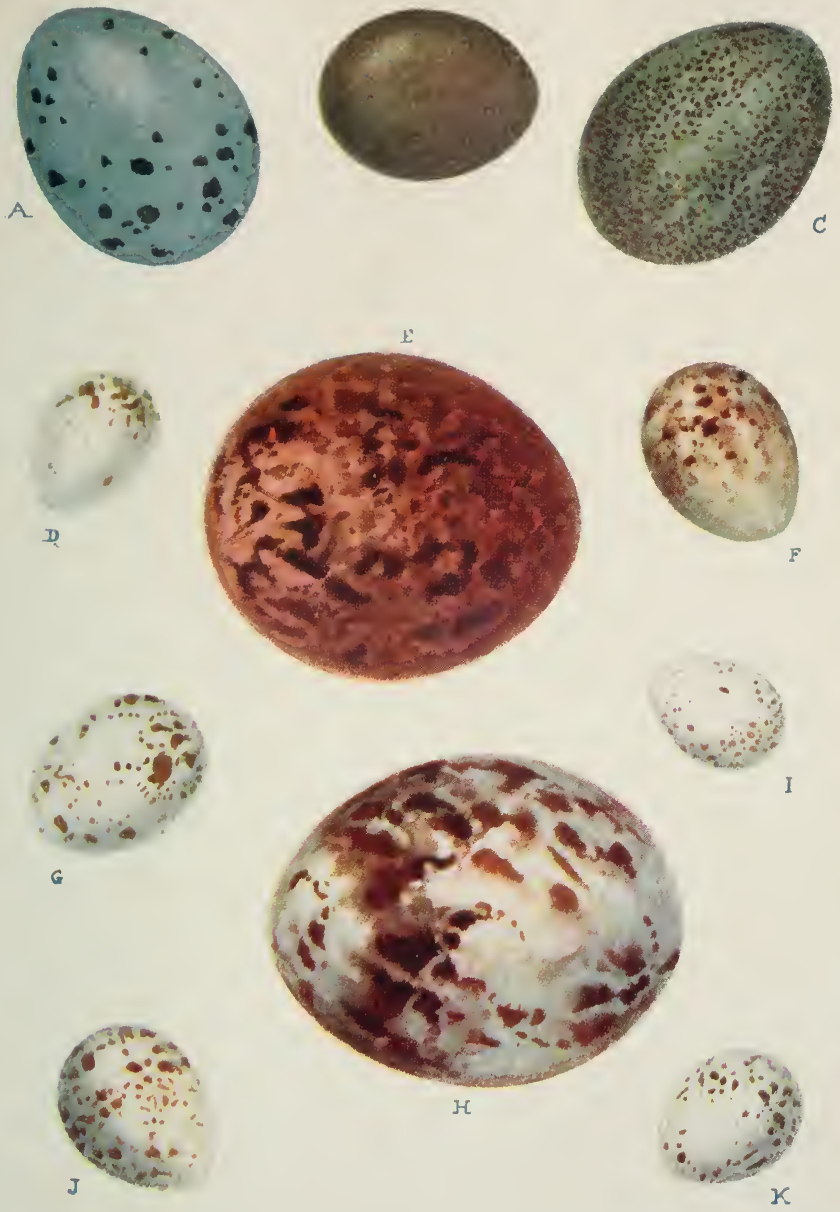

Eggs of British Birds.

ag Turlsh. I3. Nightingale C. Blackeird. D. Trfe Crebper. E. Kestrel. F. Blackcap. G. Nituatch. II. Sparrow Hawk. I. Blle Tit. J. Grieat Tit. K Cuff Chaff. 
Voice.-A plaintive call-note, prolonged in the breeding season into a kind of trill.

Chief Features.-A very beautiful bird, but of comparatively rare occurrence. Belongs to the Plover family.

Plumage.-Dull - white throat; bright chestnut, ash-brown, and black on the breast and belly, and a white band on the lower breast; dusky-black crown, margined with white, which extends backwards from the eye round the nape; ash-brown upper parts, and white-tipped tail-feathers and tail-coverts. The female, contrary to most birds, is not only larger, but richer coloured than her mate. Length.-Nine inches.

\section{DOVE, RING (Columba palumbus)}

Local Names.-Culver, Cushat, Cushat Doo, Luest, Luince, Oodal, Queest, Quist, Ring-Dow, Ring Pigeon, Wood Lueest, Wood Pigeon, Zuist.

Haunt.-Woods, parks, and fields.

Nesting Period.-An early and late breeder. March to July, often later. Site of Nest.-Trees or tall hedgerows. The matted branch of the spruce fir is a favourite site.

Materials Used.-Small dead twigs. A shallow platform, loosely made. Eggs.-Two. White, oval; size, 1.65 by 1.25 inch.

Food.-Buds and leaves, grain, berries, fruit, young clover, turnip tops, roots, and various weed seeds, especially charlock.

Voice.-A series of five or six loud notes, often repeated. Louder and harsher than those of the Turtle Dove.

Chief Features.-A very common resident bird; its numbers are largely increased by foreign visitors in Winter. A shy species; a splendid bird upon the wing. Drinks, unlike most other birds, by taking a draught of water like a Horse. Feeds its young by bringing back from its crop the soft portions of food which it has swallowed. A typical woodland species. Much better known as the Wood Pigeon.

Plumage.-Bluish-grey head, violet and green on the sides and back of neck, on each side being a patch of white; grey upper parts, with broad edges of white on wing coverts which are very conspicuous; tail-feathers dark slaty-grey; reddish-purple underneath, paler on belly; orange bill, whitish towards base; feet and legs bright red. Length.-Seventeen inches.

\section{DOVE, ROCK (Columba livia)}

Local Names.-Blue Dove, Doo, Rockier, Rockler, Rock Pigeon, White-Backed Dove, Wild Dove, Wild Pigeon.

Haunt.-High cliffs near the sea. 


\section{ROCK AND STOCK DOVES}

Nesting Period.-February to October.

Site of Nest.-Ledges of rocks, or a recess in the face of a cliff. Materials Used.-Seaweed, grass, dry bents, a few sticks or twigs. Eggs.-Two. White; size, I.45 by I.I 5 inch. Food.-Beech-mast, grain, seeds, leaves of plants, and snails. Voice. - The notes much resemble those of the Ring Dove, but with a "roo" introduced among the "coo's."

Chief Features.-A typical bird of precipitous sea cliffs. Much smaller than the Ring Dove, and distinguished as under.

Plumage.-Ashy-blue, which is lighter on the wings; white rump; a lustrous neck and breast, with beautiful purple and green reflections; on the wing there are two transverse black bands, whilst the primaries and tail are tipped with the same colour; white on the outer web of the outer tail-feathers; iris light orange; black bill; red feet. Length.—Twelve and a half inches.

\section{DOVE, STOCK (Columba cenas)}

Local Names.-Blue-Backed Dove, Blue Rock, Blue Rucker, Bush Dove, Stock Pigeon, Wood Dove, Wood Pigeon. Haunt.-Woods and sea cliffs. Nesting Period.-February to October.

Site of Nest.-Holes in trees and pollard tops, also in crevices and ledges of cliffs. In sandy districts the nest is said to be placed under a bush or in the burrow of a Rabbit. Materials Used.-Sticks and twigs. Often none. Eggs.-Two. White; size about I.45 by I.I 5 inch.

Food.-Leaves and seeds of succulent plants, snails, worms, beechmast, acorns, etc.

Voice.-A crooning, or grunting, note; a sort of continuous murmur. Chief Features.-May be mistaken, when flying, for the Ring Dove. Care should be taken to identify it from the Rock Dove, as both species often nest close together on sea cliffs.

Plumage.-Bluish-grey head, throat, wings, and lower parts; metallic reflections on the bottom portions of the neck; wine-red breast; on the last two secondaries and some of the wingcoverts there is a spot of black; primaries grey at the base, verging into dusky; grey tail, with black bars near the end, the outer feather having a spot of white on the outer web, near the base; iris reddish-brown; yellow bill, red at the base; red feet. Length.-Thirteen and a half inches. 


\section{DOVE, TURTLE (Turtur communis)}

I.ocal Names.-Common Turtle, Ring-Necked Turtle, SpottedNecked Turtle Dove, Wrekin Dove.

Haunt.-Woods, copses, and commons.

Nesting Period.-May to July.

Site of Nest.-Bushes, hedgerows, and both low and tall trees. Nest is usually just out of reach.

Materials Used.-A few twigs and sticks. A very frail homestead. Eggs.-Two. Creamy-white; size about 1.18 by .90 inch.

Food.-Insects, snails, leaves of plants, and many kinds of seeds.

I'oice.-A soft, agreeable, and frequently-repeated "Croo-oo-o."

Chief Features.-The only species of Dove which is a Summer visitor, arriving towards the end of April. Possesses a soft flight, and displays its tail fan-like when flying, the white tips of which are very prominent. It is not so gaudily attired as its relatives. It is not nearly such a harmful species as the Ring Dove, but, in spite of praise bestowed upon it by the poets, I have known it to strike at and kill a young Pheasant. Its constancy and fidelity, however, remain unchallenged.

Plumage. - A wine-red tinge on the ash head and nape; a black space on the sides of neck with tips of white; pale wine-red neck and breast; ash-brown back; dusky primaries; bluishash secondaries; wing-coverts and scapulars rust-red, with a centre spot of black; belly and under tail-coverts white; dusky tail, with all but two feathers in centre tipped with white: outside feathers with white edge externally; yellowish-red iris; red feet; brown bill. Length._Eleven and a half inches.

\section{DUCK, EIDER (Somateria mollissima)}

Local Names.-Colk, Common Eider, Dunter Duck, Edder Duck, Great Black and White Duck, St. Cuthbert's Duck.

Haunt.-Nearly always found near the sea.

Nesting Period.-Mid-May to early June.

Site of Nest.-Crevices of rocks, or on ground among plants.

Materials Used.-Seaweed, dry grass, etc., profusely lined with down

which the bird plucks from her own breast. A large nest.

Eggs.-Five to Seven. Pale dull green, oval in shape, and with a smooth surface.

Food.-Crustacea and shellfish.

Voice.-The male gives vent to a grunting note, and, during the breeding season, another note is uttered which resembles that of the Ring Dove. It is mostly a silent bird.

Chief Features.-The largest British nesting Duck, with the exception 


\section{TUFTED AND WILD DUCK}

of the Sheldrake. The down from the bird is very valuable, forming the eider-down of commerce. The bird sits very closely. It is a resident of the North, and is not common. A thorough sea-loving bird, only coming to land to nest.

Plumage.-Greenish bill, in the centre, half-way to the nostrils, is a wedge of black feathers, similar to those on the crown and forehead; the crown is bisected by a line of white which goes on to the nape, which is pale green, and divided by a further line of white from a patch of green on either side of neck; white cheeks, back, and wing-coverts; secondaries, which are sickleshaped, yellowish-white; almost black wing-feathers, rump, and tail, with a patch of white on each side of the last named; rosy-buff breast; black abdomen; legs and feet dull green. Female rufous-brown barred with blackish. Length.-Twentyfive inches.

\section{DUCK, TUFTED (Fuligula cristata)}

Local Names.-Black Poker, Black Wigeon, Old Hardweather (male), Tufted Pochard, Tufted Poker, Tufted Wigeon. Haunt.-Chiefly the seashore in Winter, but in Summer fresh-water lakes and ponds. Some birds also inhabit latter all the year. Nesting Period.-Mid-May to early June. Site of Nest.-Among aquatic herbage near fresh water. Materials Used.-Water plants, lined with bird's own down. Eggs.-Eight to Ten, or more. Greenish-buff, often dirty. Food.-Fish, insects, and water plants.

Voice.-A grating cry, thus, "kr-kr-kurra;" and on alighting, "currugh, currugh."

Chief Features.-Both a marine and fresh-water Duck, and although some naturalists state that it is inactive during the day and feeds at night, Sir Herbert Maxwell tells me that it is continually diving for food all day long. The tuft on the head and the black and white dress are able aids to identification.

Plumage.-Black and white; the former over the whole with the exception of the speculum, flanks, and belly, which are white. On the head and neck there is a purplish gloss; irides brilliant yellow; legs and feet dark blue. Female dark brown, the under parts brownish-grey. The male bird changes its colour in May. Length.-Seventeen inches.

\section{DUCK, WILD (Anas boscas)}

Local Names.-Mallard (male), Mallart, Stock Duck. Haunt.-Lakes, ponds, and streams, also saltings and mudflats near the sea in Winter. 


\section{BRITISH NESTING BIRDS}

Nesting Period.-April and May, sometimes earlier and later. Site of Nest.-Among rushes and sedges near water, or in a wood. Materials Used.-Aquatic plants and grass.

Eggs.-Ten to Twelve. Pale green.

Food.-Water insects, frogs, fish and their spawn, grain, etc. Voice.-Call, "quack," as well as "quork," or " dree-k, dree-k." Chief Features. - This is a fine sporting bird, and a splendid fier when once well on the wing. The male in his best plumage is a really handsome bird, and easily outvies in the luxury of dress his sober-clad mate. The Duck (female) and Drake (male) moult at different times. The latter goes into hiding as soon as his mate commences to sit. He then moults and comes forth in the garb of the female! In the Autumn a further change of plumage takes place, and it is then that he assumes the beautiful attire in which he is seen during the Winter months. Many foreign Ducks come over in Winter and meander along the saltings and mudflats.

Plumage.-The bill is yellowish; glossy green head and neck, with a ring of white following; deep chestnut on hind neck and breast; greenish-purple speculum, borlered above and below with white, is across the secondaries; black rump, as well as upper tail-coverts, and the curled tail-feathers, which are four in number, the remaining feathers of the tail being grey; flanks and belly greyish-white; velvet-black under tail-coverts; orange-red legs and feet. The female is smaller, and has a greenish bill; dark-brown crown; and the general plumage is mottled brown and buff. Length.-Twenty-four inches.

\section{DUNLIN (Tringa alpina)}

Local Names.-Bull's Eye, Bundie, Churr, Dunlin Sandpiper, Least Snipe, Ox Bird and Purre (young), Oxcye, Plover's Page, RedNecked Sandpiper (immature), Sea Lark, Sea Snipe, Stint, Wag Tail (young).

Haunt.-Fens and moors in Summer, as well as seashore and marsh lands, but latter chiefly in Winter.

Nesting Period.-May or June.

Site of Nest.-A depression in the ground, the nest generally being hidden by grass, heather, or rushes.

Materials Used.-Roots, dry grass, or bents, sometimes a little moss and a few twigs.

Eggs.-Four, pointed. Greenish-white, blotched with reddish-brown. Food.-Small crustaceans and insects.

Voice.-A hoarse, grating cry, but in the Spring the male utters a trilling love-call. 


\section{DUNLIN AND GOLDEN EAGLE}

Chief Features.-A well-known member of the Sandpiper family. Its numbers are greatly increased in the Autumn by immigrants from the North. It then becomes conspicuous on our coasts, and little companies are continually sweeping by, or may be observed searching for food. When a flock is seen on the wing and the light is good, the effect produced, as first the upper and then the under side are displayed, is very pleasing.

Plumage. - Rufous crown with black streaks; chestnut mantle with black variegations; rest of upper. parts

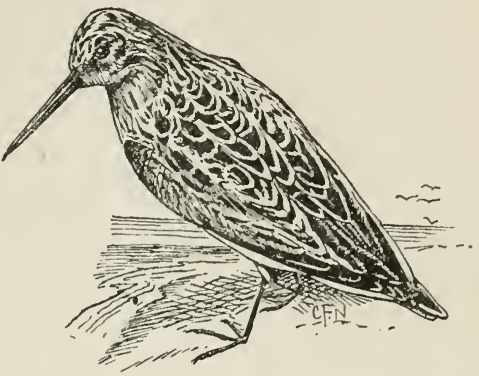

Fig. Io. Dunlin. grey; throat and upper portion of breast greyish-white and striped; lower breast black; white belly. In Winter the plumage is more or less grey above; white underneath, with a band of grey on the lower breast. Length.-Female, eight inches.

\section{EAGLE, GOLDEN (Aquila chrysaëtus)}

Local Name.-Ring-Tailed Eagle (immature).

Haunt.-Mountains, lonely glens, and forests in the North of Scotland, and also in Ireland.

Nesting Period.-March and April, sometimes later.

Site of Nest.-A precipitous crag, hillside, or tall tree.

Materials Used.-Twigs, sticks, rushes, heath, etc.

Eggs.-Two, occasionally Three. Round in shape, dirty white in

ground colour, blotched and clouded with various shades of red or reddish-brown.

Food.-Rabbits, hares, rats, young lambs, fawns, grouse, etc.

Voice.-Call-note, "bark" or "yelp," frequently repeated, as well as a shriek.

Chief Features.-Owing to protection has increased of recent years, but this has had to be withdrawn in some instances because of harm perpetrated. Most solicitous for its offspring, and feeds them with unremitting attention.

Plumage.-Head, back of neck, and legs reddish-brown and lustrous; remaining portions of body dark brown; nearly black primaries; brownish-black secondaries; dark-grey tail, ink bars and tips of brownish-black; the strong beak is bluish at base, and black at tip; brown iris; cere and feet yellow; the powerful talons are bluish-black. Length.-Male, thirty-six inches. 


\section{EAGLE, WHITE-TAILED (Haliaëtus albicilla)}

Local Names.-Cinereous Eagle, Common Gannet, Erne, Fen Eagle, Rough-Footed Eagle, Sea Eagle.

Haunt.-Same as Golden Eagle, but more often near the sea and large lakes.

Nesting Period.-March to May.

Site of Nest.-Same as Golden Eagle.

Materials Used.-Same as Golden Eagle.

Eggs.-Two. Rounded; white; rough in texture.

Food.-Small mammals, putrid flesh, fish, and aquatic birds.

l'oice. - Shriller and more of a yelping cry than the Golden Eagle.

Chief Features.-A rarer birc than the last named. The nesting site is almost always quite unassailable. A bold, courageous species, and often has a pitched battle with another of its relatives. The different plumage and white tail serve to distinguish it from the Golden Eagle.

Plumage.-Brown above, the head and neck lighter than the rest; chocolate-brown underneath; white tail; yellowish-white bill, cere, and feet; black claws. The tail of the young is brown. Length.-Male, twenty-eight inches; female, thirty-four inches.

\section{FALCON, HOBBY (Falco subbuteo)}

Local Names.-Hobby, Hobby Hawk, Merlin (Shetlands). Haunt.-Woods, and open country when hunting for food. Nesting Period.-End of May and June.

Site of Nest.-Tall trees. Often usurps the nest of a Magpie or Crow. Materials Used.-Sticks, twigs, dry grass, roots, etc.

Eggs.-Generally Three, rarely Four. Pale yellowish-red in ground colour, freckled and mottled with deeper shades; very round. Food.-Large and small birds, such as partridges, larks, young ducks, and pheasants.

Voice.-A shrill chatter, and a call-note like " pree, pree."

Chief Features. - The only bird of prey that is a regular Summer Migrant, reaching us from Africa and India during April. By no means abundantly distributed. Very courageous, and pursues its prey with great facility.

Plumage.-Bluish-black above; reddish-yellow with longitudinal brown streaks underneath; moustaches black and broad; lower tail-coverts and legs reddish; bluish beak, clark at the tip; cere greenish-yellow; iris dark brown; yellow feet; black claws. In the female the colours are duller, and broader streaks below. Lengtk.-Twelve to fourteen inches. 


\section{FALCON, PEREGRINE (Falco peregrimus)}

Local Names.-Black-Backed Falcon, Blue-Backed Falcon, Blue

Hawk, Cliff Hawk, Duck Hawk, Haggard Falcon, Lamer,

Passage Hawk, Red Falcon, Spotted Falcon, Tassel. Haunt.-High cliffs bordering the sea, and mountains.

Nesting Period.-April to June.

Site of Nest.-Inaccessible ledges of rocks and sea cliffs.

Materials Used.-Sticks, straw, bents, and rabbit flick.

Eggs.-Four. Reddish-brown, closely speckled and blotched with darker variegations.

Food.-Grouse, snipe, young sea and other birds.

Vice.-A squeak something like that of the Sparrow Hawk.

Chief Features.-Our most beautiful British Falcon, but by no means well distributed. Greatly persecuted in many instances where its eyries are known. A graceful bird on the wing, with remarkable powers of endurance.

Plumage.-Dark bluish-grey above, with bands of a darker hue; bluish-black head, and moustaches which descend from the gape; white underneath; transverse bars of brown on breast; blue beak, growing darker towards the tip; cere yellow; darkbrown iris; yellow feet; black claws. The plumage of female is tinged with brown, and underneath with reddish-yellow. Length.- The male is fifteen inches, and his mate two inches longer.

FLYCATCHER, PIED (Muscicapa atricapilla) Local Names.-Coal Finch, Cold Finch, Epicurean Warbler. Haunt.-Woods, copses, and the like.

Nesting Period.-May and June. Site of Nest.-Holes in decayed trees.

Materials Used. - Leaves, hay, and bark, with hair and feather lining.

Eggs.-Five. Very pale greenishblue. Food.-Insects.

Voice. - Alarm - note, " chuck, chuck," and a subdued, pleasant song.

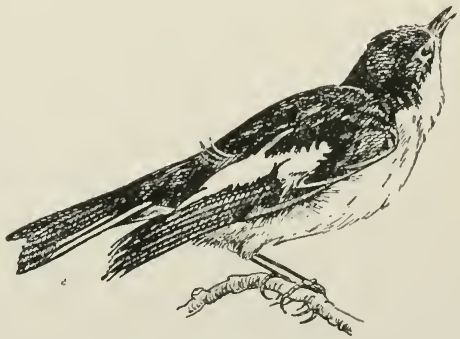

Fig. II. Pied Flycatcher.

Chief Features.-Not nearly so common as the next species, but easily distinguished by different plumage. Very local in dis- 
tribution, and needs looking for. Like its relative, it is a Summer Migrant, arriving in May.

Plumage.-A clouble moult takes place, occurring in Autumn, and again in the Spring. Above the colour is black, including the tail; the same on wings, with white on central coverts; white edging on scapulars; white underneath. The female is greyishbrown in lieu of the black; the white parts are not so pure, and the thrce lateral feathers of the tail have white edges. Length.-Five inches.

\section{FLYCATCHER, SPOTTED (Muscicapa grisola)}

Local Names.-Beam Bird, Bee Bird, Chait, Chanchider, Cherry Chopper, Cherry Snipe, Cherry Sucker, Cobweb Bird, Fig-Eater, Gray Flycatcher, Miller, Post Bird, Rafter, Wall Bird, White Baker, White Wall.

Haunt.-Woods, copses, plantations, lanes, orchards, and gardens. Nesting Period.-May to July.

Site of Nest.-Holes in trees and walls, in an arbour, among ivy on a wall, between old posts, etc.

Materials Used.-Leaves, moss, fine grasses, and a little hair.

Eggs.-Four or Five. Greyish-white, with a blue tinge, freckled with orange-brown.

Food.-Soft insects captured upon the wing.

Voice.-A silent species, but utters a curious note like "u-tick."

Chief Features.-Often overlooked owing to inconspicuous plumage, but is quite a common bird. Has a favourite watch-tower, such as a rail or arm of a tree, and from thence takes little flights into the air after insects. Has a remarkable power upon the wing, controlling its movements with great deftness and precision. A most beneficial species, for I have known one bird to capture forty-five insects in fifteen minutes. A Summer Migrant, arriving in May.

Plumage.-Ash-brown above; a central dark line on the head feathers; white underneath, the sides being marked with longitudinal brown streaks; red-tinged flanks. Length.-Five and a half inches.

\section{GADWALL (Chaulelasmus streperus)}

Local Names.-Gray, Gray Duck, Grey, Grey Duck.

Haunt.-Fresh waters.

Nesting Period.-May and June.

Site of Nest.-Among reeds and rushes.

Materials Used.-Dry grass, leaves, and rushes, lined with down. 


\section{GADWALL AND GANNET}

Eggs.-Five to Seven, or more. Creamy-white or pale buff. Food.-Water insects, spawn and fry of fish, seeds, and plants. Voice.-A repeated "quack, quack."

Chief Features.-Our rarest Fresh-water Duck, something like the better-known Wild Duck, but neither so large nor handsome. Largely nocturnal in habits. A splendid bird upon the wing, and an expert diver.

Plumage.-Has a lead-coloured beak; light-brown head and upper neck mottled with darker shades; light grey on a dark ground is present on the back; median wing-coverts chestnut; greater coverts blackish; brown on primaries; black and brown secondaries, a white speculum being formed in the outer webs; bluish-black rump and upper tail-coverts; dark-brown tail feathers edged with paler tints; lower neck dark grey, each feather with a pale-grey margin; white breast and belly; grey flanks and vent; under tail-coverts bluish-black; orange legs and feet. Female, light-brown head and upper neck, mottled with darker shades; lower hind neck and upper parts brown; white on speculum and underneath. Length.-Twenty-one inches.

\section{GANNET (Sula bassana)}

Local Names.-Channel Goose, Gan or Gant, Solan Goose.

Haunt.-Rocky parts of the coast.

Nesting Period.-May and June.

Site of Nest.-Ledges of precipitous rocks.

Materials Used.-Seaweed, grass, straw, etc. An untidy nest.

Eggs.-One. White, but often becomes stained; chalky.

Food.-Fish, especially sprats, pilchards, mackerel, and herrings.

Voice.-A harsh cry, which is something like " carra, carra, carra."

Chief Features.-A magnificent bird upon the wing; mounts high in the air before taking a headlong and superb dive into the sea beneath. Eyes must be of great microscopic power. Has a dagger-like beak. Dark stripe near eye very characteristic. The Bass Rock is a notable nesting station, I0,000 pairs of birds being said to breed there each season.

Plumage.-The adult has a buff-coloured head and neck, and the remainder of the plumage white, with the exception of the primaries, which are black. In the young the first year's dress consists of blackish-brown upper parts flecked with white; dusky-ash and buff underneath. With the sixth year the dark markings disappear, and the dress of the adult bird is put on. Length.-Thirty-four inches. 


\section{BRITISH NESTING BIRDS}

\section{GARGANEY (Querquedula circia)}

Local Names.-Crick, Cricket Teal, Gargle Teal, Pied Wigeon, Pied

Wiggon, Red Wiggon, Summer Duck, Summer Teal.

Haunt.-Fresh waters.

Nesting Period.-April and May.

Site of Nest.-Among aquatic herbage, the nest being well hidden. Materials Used.- Water plants and surrounding herbage, lined with the bird's own down.

Eggs.-Ten to Twelve. Creamy-white or buff, resembling those of Teal.

Food.-Fish and their spawn, aquatic insects, frogs, and grain.

Voice.-A curious jarring note has resulted in this Duck being called

the Cricket Teal in some localities. It is the male that utters

this low note, but when on the wing a sharp, double quacking cry is also emitted.

Chief Features.-A very swift bird upon the wing, flying with neck outstretched and the legs hanging down. It resembles the Teal in many of its habits, and is a near relative of that species. Plumage.-Black bill; dark brown on head, crown, nape, and back; a strip of white extends from the eye to the back of neck; cheeks and neck light brown, with short, hair-like lines of white; black scapulars, with white stripe in centre; bluish-grey on wing-coverts; green speculum, bordered on either side with two white bars; dull-brown primaries and tail; black chin; pale-brown breast, with darker bands of a crescent order; white belly; flanks with transverse lines of black; tail-coverts underneath black and white; greyish-brown legs and feet. The female is mottled-brown, with the eye stripe yellowish-white, and the speculum dull metallic green, barred on either side with white. Length.-Sixteen inches.

\section{GOLDFINCH (Carduelis elegans)}

Local Names.-Brancher, Chalandire, Chardonneret, Coalhead, Draw Water, Fool's Coat, Goldie, Goldspink, Gooldic, Goudspink, Grey Kate, Grey Pate (young), Jack Nicker, King Harry, Proud-Tail, Proud-Tailor, Redcap, Red-Fronted Thistle Finch, Seven-Coloured Linnet, Sheriff's Man, Sweet William, Thistle Finch.

Haunt.-Orchards, large gardens, commons, and woods.

Nesting Period.-May onwards.

Site of Nest.-Fruit trees in an orchard or garden, also spruce fir, evergreens, and hedgerows. 
Materials Used.-Moss, lichen, wool, hair, etc. Nest is very similar to that of the Chaffinch, but shallower.

Eggs.-Four or Five. Pale grey or bluish, spotted with greyishpurple and red-brown. Sometimes streaked as well as spotted. Food.-Weed seeds, and especially fond of thistles when the latter are seeded in Autumn.

Voice.-A bright, cheery call, consisting of several notes rapidly uttered. The song is also very shrill, and parts of it are of a high order.

Chief Features.-This bird was rapidly decreasing, but, as a result of protection, is now on the increase. Being handsomely attired and very active in its habits, this is a favourite Finch. The male and female are, contrary to most birds, very much alike. The young are quite different, and are called Grey Pates. Plumage.-Black head at the back, as well as the nape and feathers round the base of the bill; front of head and throat blood-red; white cheeks, fore-neck, and under parts; dark-brown back and scapulars; wings are variegated with white, black, and yellow; black tail, tipped with white. Length.-Five inches.

\section{GOOSANDER (Mergus merganser)}

Local Names.-Dun Diver, Harle Duck (female or young male), Jack-Saw, Sawbill, Sparling Fowl.

Haunt.--Inland waters as well as the sea.

Nesting Period.-April and May.

Site of Nest.-Banks of fresh-water lochs, among grass, in a hole, under a rock, or in a hollow tree-stump.

Materials Used.-Moss, dry grass, roots, etc., with a lining of down from the bird's own body.

Eggs.-Seven or Eight. Oval in shape; creamy-yellow or buff. Food.-Fish.

Voice.-A low whistling cry.

Chief Features.-Chiefly a Winter visitor, but breeds in the North of Scotland. As the Latin name implies, it is a Merganser. It assumes an awkward attitude on land, as the legs are placed very far back, but when on or in the water it is very alert and swift in its actions. Has a serrated bill, which enables the bird to more securely hold its prey.

Plumage.-Blood-red bill and irides; glossy dark-green head and upper neck; neck underneath and under parts white with a salmon-pink tinge; black scapulars and upper back; white on wing-coverts; primaries and some of the secondaries ashbrown; ash-grey on lower back and tail; orange-red legs and feet. The female is not so richly dressed as her mate, and is reddish-brown on head and neck. Length.-Twenty-six inches. 


\section{BRITISH NESTING BIRDS}

\section{GOOSE, GREY-LAG (Anser cinereus)}

Local Names.-Fen Goose, Grey Goose, Grey-Legged Goose, Quinck, Wild Goose.

Haunt.-Northern moors, swamps, and morasses.

Nesting Period.-March to May.

Site of Nest.-On the ground.

Materials Used.-Sticks as a foundation, then grass, sedges, and

dead leaves, lined with down. The same nest is used each

season after being repaired, and thus soon becomes very large.

Eggs.-Six to Twelve. Dull creamy-white.

Food.-Grain, grass, and young shoots.

Voice.-Call, "kak-kak," " gag-gag," or a noisy " gaggle."

Chief Features. - The only species of Goose which nests in a wild state in the British Isles.

Plumage.-Greyish-brown head, neck, and upper parts; dull-white lower breast and abdomen, spotted with black; rump and wingcoverts bluish-grey; flesh-coloured bill, with white nail at tip; legs and feet same colour as bill. Length.-- Thirty-five inches.

\section{GREBE, GREAT CRESTED (Podiceps cristatus)}

Local Names.-Arsfoot, Ash-Coloured Loon, Ash-Coloured Swan, Cargoose, Crested Grebe, Diver, Gaunt, Greater-Crested Doucker, Greater Dabchick, Greater Loon, Horned Dabchick, Horned Doucker, Loon, Molrooken, Tippet Grebe.

Haunt. - Fresh-water lakes, ponds, and broads.

Nesting Period.-April to June.

Site of Nest.-Among rushes, on the edges of lakes, etc.

Materials Used.-Dead and decaying water plants, such as reeds, etc.

Eggs.-Three or Four. Size, 2.2 by I. 45 inch.

White or greenish when first laid, but often become stained.

Food.-Tadpoles, frogs, fish, and insects.

l'oice. - A harsh, grating cry during the breeding season, at other times the bird is very silent.

Chief Features.-This handsome species is

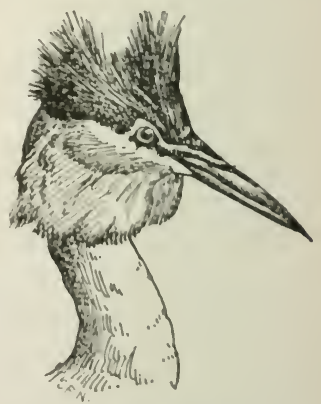

Fig. I2. Head of Great Crested Grebe.

increasing its range, and is largely protected. The curious head of the male at once identifies it. Very solicitous for the welfare of its young, and these remain with their parents for 


\section{LITTLE GREBE AND GREENFINCH}

some time. The eggs are often covered over when the parent bird leaves the nest in the same way as those of its smaller relative.

Plumage.-Dark-brown and chestnut crown, crest, and ruff; white cheeks; dark-brown upper parts; white secondaries; silkywhite underneath. Length.-Twenty-two inches.

\section{GREBE, LITTLE (Tachybaptes fuviatilis)}

Local Names.-Arsfoot, Black-Chinned Grebe, Dabber, Dabchick, Didapper, Dive Dapper, Dob-Chicken, Ducker, Small Doucker,

Tom Pudding.

Haunt.-Fresh-water lakes, ponds, and streams.

Nesting Period.-March to August.

Site of Nest.-Near, and often on, the water, Sometimes the nest

is exposed, at others hidden among

aquatic vegetation.

Materials Used.-Grasses and reeds. A flat structure.

Eggs.-Four to Six. White when laid, but soon become stained. Size, I. 45 by 1.0 inch.

Food.-Same as Great Crested Grebe. Voice.-A rusty call-note, and a curious so-called song, like the creaking of a gate that wanted oiling!

Chief Features. - The antics of the birds in the water are most interesting. They dive as quick as thought, and disappear as if by magic, popping up here, there, and everywhere in a most curious and delightful way.

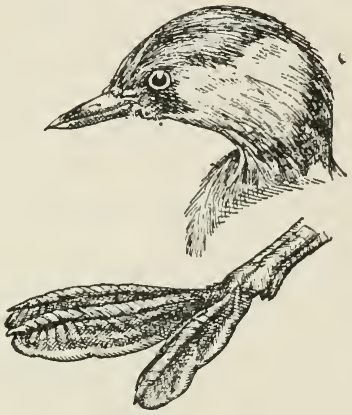

Fig. I3. Head and Foot of Little Grebe.

They paddle under water swiftly and adroitly. Far better known as the Dabchick or Dobchick.

Plumage.-Dark-brown head, neck, and upper parts; a sprinkling of white on the secondaries; black chin; reddish-chestnut cheeks, throat, and sides of neck; greyish-white underneath; dusky-brown flanks; horn-coloured bill; dull-green legs and feet curiously shaped. Length.-Nine and a half inches.

\section{GREENFINCH (Ligurinus chloris)}

Local Names.-Green Bird, Green Chub, Green Grosbeak, Green Linnet, Greenulf, Joey. Haunt.-Woods, hedgerows, fields, and gardens. Nesting Period.-April onwards. 
Site of N'est.-Hedges, bushes, shrubs, etc.

Materials Used.-Moss and grass, lined with hair. Often a large structure, and sometimes slovenly built.

Eggs.-Four to Six. White, or bluish, spotted and streaked with reddish or purple and darker shades. They vary in size, shape, and markings.

Food.-Seeds of various kinds, especially those that are oily, also buds and scraps in Winter.

Voice.-One of the few British birds which sings upon the wing. It is not a brilliant songster, although some individuals sing better than others. The characteristic note is best compared to the noise made by the bough of a tree when blown by the wind, or a gate swinging to and fro.

Chief Features.- One of our commonest Finches. The male is a handsome bird in his green and gold livery. It is most voracious, and often visits gardens for sunflower seeds.

Plumage.-Yellowish-green, with variegations of yellow and ashgrey. Length.-Six inches.

\section{GREENSHANK (Totanus canescens)}

Local Names.-Cinereous Godwit, Greater Plover, Green-Legged Horseman, Green-Shanked Godwit.

Haunt.-The coast, and also inland on moors and mountains.

Nesting Period.-Middle to end of May.

Site of Nest.-A depression in the ground. On occasions close to water, at others some distance from it.

Materials Used.-Heather, twigs, leaves, and blades of dry grass. Eggs.-Four. Creamy-white, or warm stone-colour, with purplishgrey blotches and brown spots.

Food.-Insects, worms, etc.

Voice. - A clamorous cry.

Chief Features - A rare British bird, called Greenshank because of the green legs and feet. It only nests in Scotland.

Plumage.-Greyish-white head and neck, with streaks of blackishbrown; almost black mantle and secondaries; white rump and tail-feathers, the latter with dusky-brown mottlings and bars; white under parts, with streaks and spots of ash-brown; olivegreen legs and feet. The plumage in Winter is greyer above and pure white underneath. Length.-Fourteen inches.

\section{GROUSE, BLACK (Tetrao tetrix)}

Local Names.-Black Cock, Black Game, Brown Hen, Grey Hen (female), Heath Cock, Heath Poult (female), Killockie.

Huunt.-Mnors, mountain heaths, and woods. 


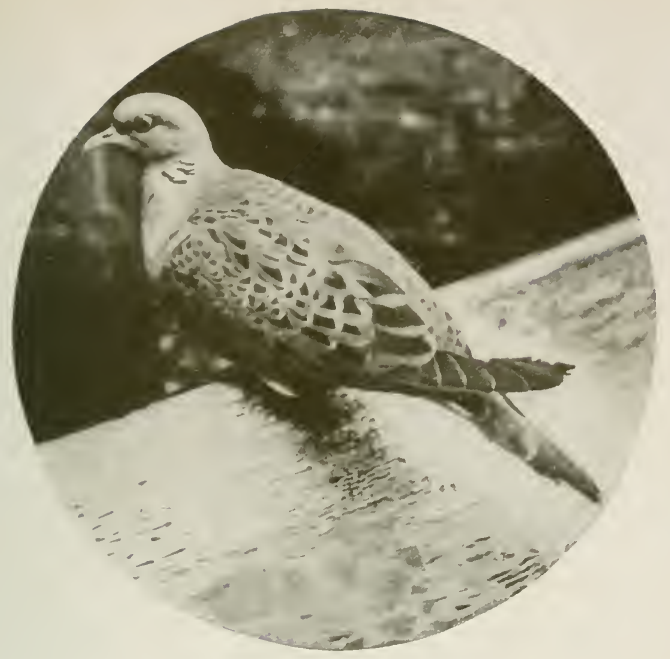

Turtle Dove.

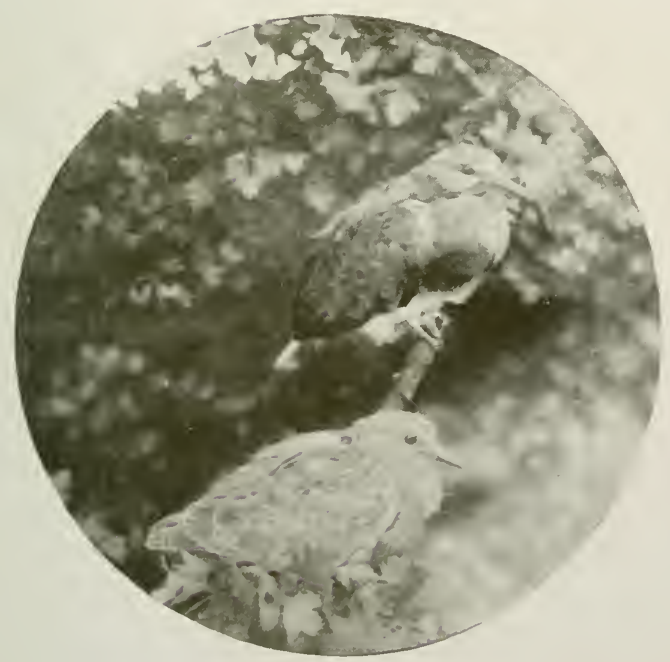

Young Turtle Doves. 


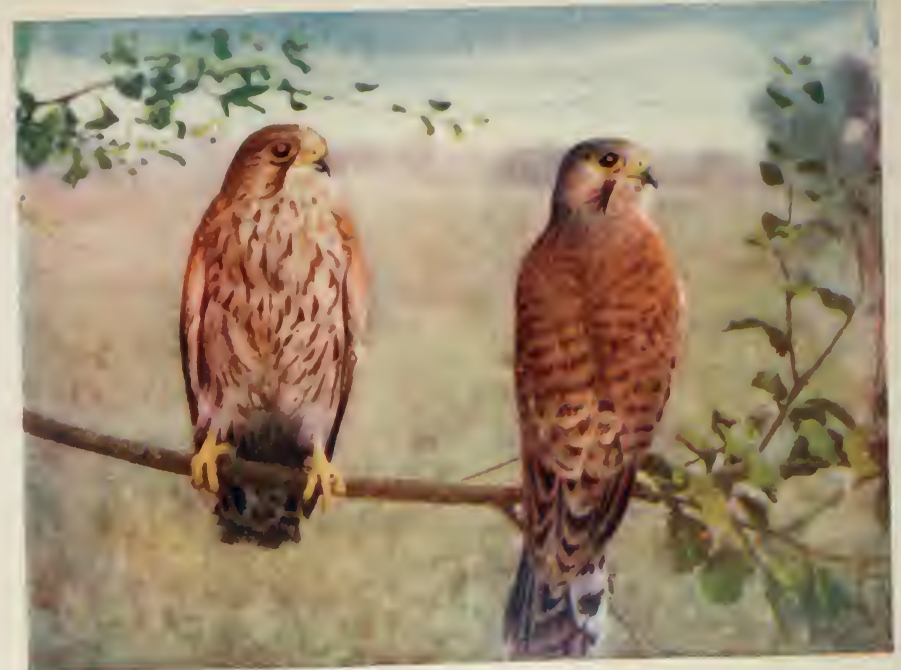

JOUNG KFATRLS.

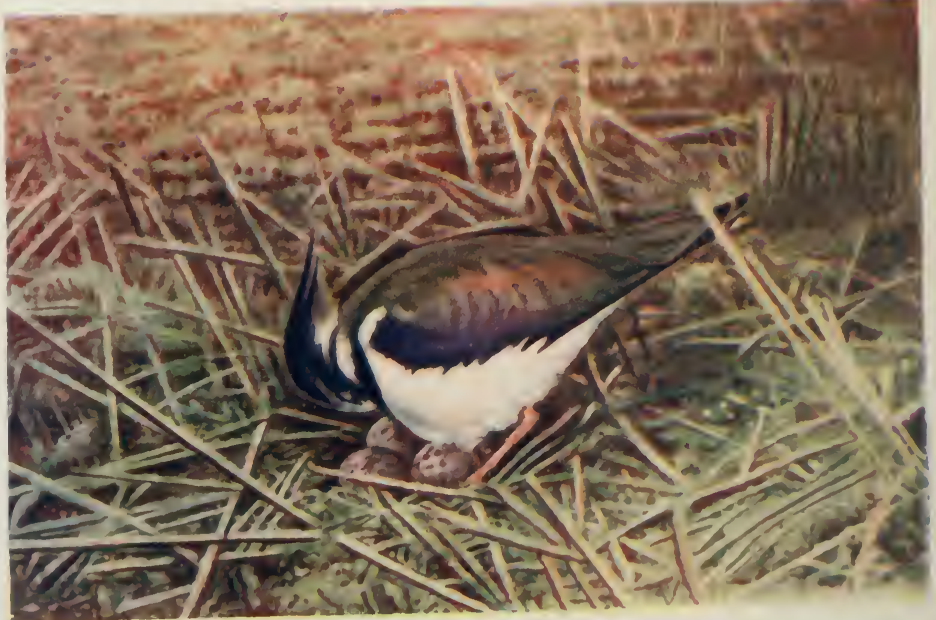

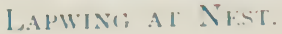




\section{BLACK AND RED GROUSE}

Nesting Period.-April to June.

Site of Nest.-On the ground among heather, fern, bramble, etc. Materials Used.-Heath, ling, fern, or grass. Not much attempt is made to build a nest.

Eggs.-Seven to Ten. Yellowish, well marked with dark brown. Food.-Insects, grain, berries, buds, etc.

Voice.-Described by Mr. Hett as: Call, male, "cooing," followed by " hissing;" otherwise " crow" (compared to the whetting of a scythe). " Response " of female a plaintive " cooing."

Chief Features.-A well-known Game bird, once plentiful in Southern England, but now mostly a resident of the North. The outermost feathers of the tail curve outwards, and these are sufficient for identification. The Black Grouse does not pair, being polygamous.

Plumage.-Bluish-black, with a tinge of brown on upper parts; across the wings there is a bar of white; the tail is black. Scarlet wattles above the eyes, and hazel irides. Length.-From twenty to twenty-three inches. The full-grown female is not so large as the male bird, and is similar to the Capercaillie in colouring, whilst the tail is not forked.

\section{GROUSE, RED (Lagopus scoticus)}

Local Names.-Brown Ptarmigan, Gorcock, Moor Bird, Moor Cock, Moor Game, Muire Fowl, Red Game, Red Ptarmigan.

Haunt.-Moors in Scotland, Ireland, North of England, and parts of Wales.

Nesting Period.-March to June.

Site of Nest.-A slight hollow under a tuft of herbage.

Materials U sed.-If any, a sprinkling of heath, ling, grass, and perhaps a few feathers.

Eggs.-Six to Fourteen; the number varies. Two types may be mentioned: one is yellowish, marked with light brown, and the other blood-red, blotched and mottled with rich umber-brown.

Food.-Young shoots, buds, leaves, and wild moorland fruits.

Voice.-Call, crow of male, "cabow, cabow, cabeck, cabeck, beck, beck;" " cockaway, cockaway;" or " go-bac, go-bac-bac-bac" (harsh). Female, "yow, yow, yow" (with peculiar nasal catch). Male, alarm, "cock, cock, cock."

Chief Features.-The only bird found in Great Britain and Ireland which does not occur in any other part of the world. For a full account of how this has come about, see my British Bird Life. It does not resort to woods like the Black Grouse, being a lover of the open moor. Easily distinguished by its plumage. Plumage.-Reddish-brown on head and neck, and chestnut-brown, 
with bars and specks of black, above; almost black on breast, with tips of white. During the Summer the general colour is lighter, whilst in Winter the under parts are often mottled with white. The female is more reddish-yellow than her mate. Length.-Sixteen inches.

\section{GUILLEMOT, BLACK (Uria grylle)}

Local Names.-Dovekie, Greenland Dove, Puffinet, Scaber, Scout, Sea Pigeon, Sea Turtle, Spotted Guillemot (a varicty), Strany,

Teiste, Tinker's Hue, Toist, Tyste.

Haunt.-Rocky parts of the sea coast.

Nesting Period.-End of May to end of June.

Site of Nest.-In a hole or crevice of a rock, or on the soil beneath. Materials Used.-None.

Eggs.-Two, occasionally Three. White, with perhaps a blue tinge, spotted, speckled, and blotched with chestnut-brown, dark brown, and a sort of neutral tint.

Food.-Fish.

Voice.-Call, a plaintive "whistle," and a kind of " grunt."

Chief Features.-Confined as a breeding species to the west coast of Scotland, and the north and west coasts of Ireland. Not so gregarious in its habits as the Common Guillemot, and quite distinct in its dress.

Plumage.-Wholly black, with the exception of some of the wingcoverts and secondary quills, which are tipped with white. The bill is black and the legs are red. Length.-Fourteen inches.

\section{GUILLEMOT, COMMON (Lomvia troile)}

Local Names.-Aron or Arron, Bridled Guillemot (a variety), Ellygug, Foolish Guillemot, Guillem, Illegug, Kiddaw, Lary, Lavy, Marrl, Ringed Guillemot (a variety), Scout, Sea Hen, Skout, Strany, Tarrock, Tinkershire, Willock (young).

Haunt.-Rocky parts of the coast. Nesting Period.-Mid-May onwards. Site of Nest.-I.edges of precipitous sea cliffs.

Materials Used.-None.

Eggs.-One only. Many different types might be mentioned, as they vary in an extraordinary way. The

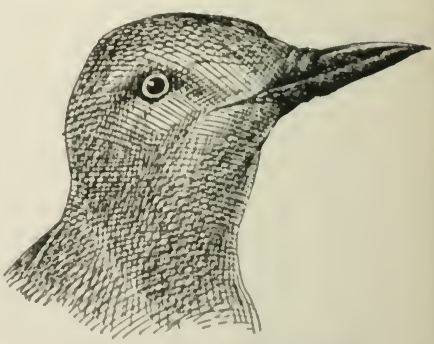

Fig. 14. Head of Common Guillemot.

ground colour varies from almost white, through various shades 


\section{BLACK-HEADED AND COMMON GULLS}

of bluish and green, strongly blotched and streaked with dark colours, and giving the egg a very handsome appearance. It is pear-shaped.

Food.-Fish, especially sprats.

Voice.-Some notes are short, like a bark, others are laughter-like and clear, and still another is a hoarse, long-drawn, howling cry. Chief Features. - Nests in large numbers, and is a very sociable bird.

To see a large company on some rocky eminence is quite a feature of our British bird life. Easily distinguished by the black and white attire.

Plumage.-Head, neck, and upper parts blackish-brown; under parts white. Length.-Eighteen inches.

\section{GULL, BLACK-HEADED (Larus ridibundus)}

Local Names.-Blackcap, Brown Gull, Brown-Headed Gull, Crock, Crocker, Hooded Maw, Hooded Mew, Laughing Gull, Masked Gull, Mire Crow, Peewit Gull, Pickmire, Red-Legged Gull, Red-Legs, Rickim-Re, Scoulton Gull, Sea Crow, Sea Gull. Haunt:-The sea and seashore, inland lakes and rivers, moors, marshes, and fields.

Nesting Period.-April and May.

Site of Nest.-Edges of lakes, on an island, among boggy plants, etc. Always on the ground.

Materials Used.-Dead grass, sedge, etc. Little attempt is made to build a nest.

Eggs.-Three. These vary through various shades of light and dark green, also blue, yellow, and brown; some varieties are heavily marked with dark spots, and others only sparingly. Food.-Very fond of sprats, but picks off the sea various floating matter, and also feeds largely on insects and their larvæ.

Voice.-Sometimes called Laughing Gull because of the curious laughter-like notes.

Chief Features.-Immediately identified by blackish-brown head in

Summer. Has many favourite nesting haunts in England, and breeds in immense numbers. One of our commonest species.

Plumage.-Red bill and feet; blackish-brown head and upper neck; grey mantle; the rest of plumage white, with a tinge of pink underneath. The blackish-brown head is missing in Winter. Length.-Sixteen inches.

\section{GULL, COMMON (Larus canus)}

Local Names.-Blue Maa, Cob, Coddy Moddy (young), Grey Gull (young), Marrot, Mew (immature), Phirgie, Sea Cob, Sea Gull (ALL the Gulls often so called), Sea Mall, Sea Maw, Sea Mew, 
Storm Gull, Umber Gull (young), White-Footed Gull, Winter

Bonnet, Winter Gull (young), Winter Mew (young).

Haunt.-Very similar to the Black-Headed Gull.

Nesting Period.-May and June.

Site of Nest.- On low grassy islands near the sea, also lochs, inland

lakes, etc. Sometimes, but not very often, on cliffs.

Materials Used. - A much larger nest than that of the last-mentioned

species. Sea plants, including seaweed, as well as heather, dry grass, stalks, etc.

Eggs.-Two or Three. They vary a great deal, the ground colour being green, brown, light blue, or straw-colour. Some are not very strongly marked, others are profusely blotched and spotted with ash and dark brown, and others again are streaked with brown, but only have a few ash spots.

Food.-Small vertebrates, fish, carrion, worms, insects and larvæ. Voice.-A clamorous " yak," and laughter-like "luka, luka, luka," "kyah," and "kree."

Chief Features.-Although called Common Gull it is not so abundant as the Black-Headed species. Note the difference in the colour of bill, legs, and feet.

Plumage.-The base of the bill greenish, with a yellow tip; greenishyellow legs and feet; ash-grey mantle; black on the two first primaries, with a patch of white near the extremity, the remainder black towards the end; white head, neck, tail, and under parts. Length.-Eighteen and a half inches.

\section{GULL, GREAT BLACK-BACKED (Larus marinus)}

Local Names.-Black-back, Brown and White Gull (young), Cob, Cob Farapack, Great Black and White Gull, Swabie, Swat-Back, Wagel.

Haunt.-More fond of the sea than its relatives; haunts tidal rivers and mudflats, also moors near the sea.

Nesting Period.-May and June.

Site of Nest.-On top of a cliff, and also similar sites to those of the Black-Headed Gull. Usually, however, more inaccessible.

Materials Used.-Seaweed and other plants, sometimes lined with wool and a few feathers.

Eggs.-Three. Large handsome eggs, dark olive-green or brown, heavily marked with darker shades.

Food.-Dead animal matter found floating on the sea, as well as fish; plunders the nests of sea birds and Grouse for both eggs and young. A pirate.

Voice.- "Ag, ag," often repeated, and a yelping "kyauk." Chief Features.-Our largest and most striking British Gull. A 


\section{HERRING AND KITTIWAKE GULLS}

great robber, the male and his mate quartering the ground "like a brace of pointers." I have known the nest to be located two miles from the sea, but, in spite of the distance, food was largely secured from the ocean.

Plumage.-Yellow bill; flesh-coloured legs and feet; rest of plumage as in the case of the Lesser Black-Backed Gull. Length.Thirty inches.

\section{GULL, HERRING (Larus argentatus)}

Local Names.-Cat Gull, Goose Gull, Scorey, Silvery Gull, YellowLegged Gull.

Haunt.-Sea cliffs, saltings, large rivers near the sea, and mudflats. Nesting Period.-May and June.

Site of Nest.-Ledges of rocks and grassy cliff-sides.

Materials Used.-Seaweed and grasses.

Eggs.-Three. Yellow to green or brown in ground colour, blotched with ash-grey and dark brown.

Food.-Fish (including herrings), carrion, insects, worms, eggs, and young birds.

Voice.-Mr. Hett compares the call to "ak-ak;" "cou-1-ooë;" "hak-hak-hak" or "hau-hau-hau;" "croak," and "pee wheel;" alarm, "ky-eok" repeated several times, especially when disturbed at nesting-places, not often otherwise.

Chief Features.-Absence of black markings is worth noticing, the grey plumage generally being a distinguishing feature, as well as the size. Said by competent naturalists to perpetrate harm among salmon smolts when latter are descending rivers in May and June.

Plumage.-All the Gulls in Britain, with the exception of the first one on our list - the Black-Headed-have yellow bills or greenishyellow; the legs and feet of the Herring Gull are the same colour as those of the Great Black-Backed; grey mantle; white head, tail, and lower parts: outermost primaries black. Length.-Twenty-four inches.

\section{GULL, KITTIWAKE (Rissa tridactyla)}

Local Names.-Annet, Kittiwake, Tarrock (immature), Waeg. Haunt.-Rocky parts of the coast.

Nesting Period.-End of May and beginning of June.

Site of Nest.-Ledges of rocky sea cliffs.

Materials Used.-Marine plants, lined with dry grass.

Eggs.-Three. Stone-coloured or olive in ground colour, blotched and spotted with ash-grey and two or three shades of brown. Food.-Small fish. 
Voice.-Three otes, somewhat resembling the bird's name, the first two quickly uttered and the third long. It has also been compared to " ah-get-away, ah-get-away."

Chief Features.-The smallest British Gull. A beautiful bird in its soft grey dress. Sociable, and fairly plentiful on rocky parts of coast. Captures fish after the manner of the Terns.

Plumage.-Bill greenish-yellow; black legs and feet; deep-grcy mantle; white head, neck, tail, and under parts. Length.Fifteen and a half inches.

\section{GUILL, LESSER BLACK-BACKED (Larus fuscus)}

Local N'ames.--Grey Gull, Yellow-Legged Gull (young).

Haunt.-Islands near fresh water are favourite haunts, but also sea coast and hillsides adjacent to the sea.

Nesting Period.-Latter part of May and beginning of June.

Site of Nest.-A depression in the ground, or in a crevice.

Materials Used.-Seaweed and grasses.

Eggs.-Two or Three. The ground colour and markings both

vary. Some are a warm stone-colour, through shades of brown to pale green or light olive-green, blotched and spotted with chestnut and dark brown, or a neutral tint.

Food.-Fish, worms, grubs, and offal.

Voice.-Short and long cries; laughter-like and weird.

Chief Features.-About the same size as the Herring Gull, and often nests in close proximity. It is gregarious, and its smaller size at once distinguishes it from the Great Black-Backed.

Plumage.-Yellow bill, legs, and feet; white plumage in Summer, with exception of mantle, which varies from slate-grey to black. Length.-Twenty-three inches.

\section{HARRIER, HEN (Circus cyaneus)}

Local Names.-Blue Gled, Blue Hawk, Blue Kite, Dove-Coloured Falcon, Dove Hawk, Kattabella, Pigeon Hawk, Ring-Tailed Harricr (female), White Hawk.

Haunt.-Wild moorlands, and similar haunts.

Nesting Period.-May and June.

Site of Nest.-On the ground on a desolate moor, or in a reed-patch or cornfield.

Materials Used.-A few twigs and dry grass.

Eggs.-Four to Six. Bluish-white, with perhaps a few rusty spots. Food.-Mice, moles, frogs, small birds and their eggs, and insects.

Voice.-A frequently-uttered "ker."

Chief Features. - The commonest of the three British Harriers, but 
even this species is rare. It has, like its relatives, been ruthlessly persecuted by gamekeepers. The Harriers possess a habit of beating to and fro after their prey. They do not hover like the better-known Hawks, quartering the ground and dashing down on their prey unawares. Their powers upon the wing are very remarkable.

Plumage.-The adult male is bluish-grey above, white underneath; black beak; reddish-brown irides; yellow legs and feet; black claws. The female has reddish-brown above; pale reddishyellow underneath, with longitudinal streaks and spots of deep orange-brown. Length.-Male, eighteen inches; female, two inches longer.

\section{HARRIER, MARSH (Circus aruginosus)}

Local Names.-Bald Buzzard, Duck Hawk, Dunpickle, Harpy, March Harrier, Marsh Hawk, Moor Buzzard, Puttock, WhiteHeaded Harpy.

Haunt-Marshes, swamps, and the like.

Nesting Period.-May.

Site of Nest.-On the ground among reeds, fern, or furze. Materials Used.-Sedge, reeds, and sticks. A large nest.

Eggs.-Three to Six. White, milky-white, or bluish-green, some-

times lightly marked with light brown. Round and rough. Food.-Mice, voles, birds, and, it is said, fish.

Voice.-Male cries "koi " or "kai ;" female, "pitz" and " peep."

Chief Features.-Almost extinct as a British breeding bird, being restricted at the present time to one or two English counties.

Plumage.-The adult has a creamy-white head and nape, with streaks of dark brown; reddish-brown is the remaining colour above, with paler margins to the feathers; black primaries; ash-grey secondaries and tail; chestnut-brown underneath. Length.-About twenty-two inches. The female closely resembles her mate, but is a little larger.

\section{HARRIER, MONTAGU'S (Circus cineraceus)}

Local Names.-Ash-Coloured Falcon, Blue Jacker.

Haunt.-Heaths, commons, and marshes.

Nesting Period.-May.

Site of Nest.-On the ground among heath or furze, also among clover and corn.

Materials Used.-Rushes, dry grass, and a few twigs.

Eggs.-Four or Five. Almost similar to those of the Marsh Harrier. Food.-Moles, frogs, the eggs and young of small birds, insects, etc. 
Voice.-A feeble and tremulous chatter.

Chief Features.-This Harrier does resort to hovering like a Hawk, but, in spite of this habit, is more fond of keeping to the ground than its two British relatives. This species is named after Montagu, who was the first ornithologist to point out its right to inclusion as a British bird.

Plumage.-Bluish-grey above; black primaries; three transverse dark bars on secondaries; white lateral feathers of tail barred with reddish-orange; white underneath, streaked in a varying manner with reddish-orange. The female has various tints of brown above, and pale reddish-yellow below, with bright-red streaks of a longitudinal character; black beak; yellow legs and feet. Length.-Eighteen inches.

\section{HAWFINCH (Coccothraustes vulgaris)}

Local Names.-Black-Throated Grosbeak, Cherry Finch, Chuck, Cobble Bird, Grosbcak, Ground Wren, Haw Grosbeak, Kate.

Haunt.-Woods, commons, hedgerows, and large gardens.

Nesting Period.-May.

Site of Nest.-Usually from five to twenty-five feet from the ground in a tall bush or tree, such as holly and fir, or among ivy.

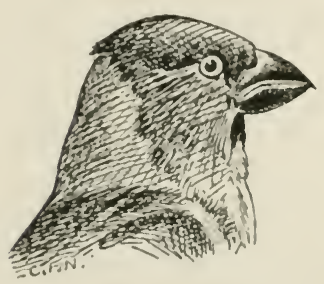

Fig. 15. Head of Hawfinch.

Materials Used.-Small twigs, plant stems, and lichen, lined with hair and roots. Sometimes no hair is present. A loosely-made but not untidy nest.

Eggs. - Three to Five. Greenish-grey, streaked with bluish-black, and spotted with brown.

Food.-Insects, berries, and fruit. Very fond of peas.

Voice.-A low, plaintive note of a pleasant description.

Chief Features. - A bold, handsome Finch, at once identified by the large head and strong, massive beak. Very local in distribution.

Plumage.-Black on lores, throat, and base of bill; reddish-brown checks and crown; ashy-grey nape; dark reddish-brown back: black wings, white on great coverts; light purplish-red underneath. Length.-Seven inches.

\section{HAWK, SPARROW (Accipiter nisus)}

Local Names.-Blue Hawk, Bluc Merlin, Gwepia, Pigcon Hawk. Haunt.-Woods, commons, sea cliffs, and open ficlds. Nesting Period.-April to Junc. 
Site of Nest.-Trees and large bushes, also on rocks and sea cliffs. Materials Used.-Twigs and sticks. Often takes possession of the deserted nest of a Jay or Crow.

Eggs.-Five. Whitish, handsomely blotched at the larger end with reddish-brown. Sometimes the markings are distributed over almost the whole surface.

Food.-Moles, mice, birds, beetles, cockchafers, slugs, etc.

Voice.-A harsh, screaming call, representing the word "mew." Chief Features.-A bold bird of prey, always worth observing. Glides through the air, then free-wheels, as it were, and hovers. It dashes after its prey with great rapidity.

Plumage.-Above the colouring is dark bluish-grey, with a spot of white on the nape; underneath reddish-white, with transverse bars of deep brown; grey tail, barred with brownish-black; blue beak; yellow cere, irides, and feet. In the female the upper parts are brown, passing into blackish-grey; underneath greyish-white, with dark-grey bars. Length. - The male is twelve inches, female three inches more.

\section{HERON (Ardea cinerea)}

Local Names.-Hanser, Harnsea, Hearinsew, Hegrilskip, Hern, Heronshaw, Heronswegh, Jack Hern, Kate Hern, Long-Necked Heron, Moll Hern.

Haunt.-Woods, marshes, saltings, sea cliffs, and rivers.

Nesting Period.-March onwards.

Site of Nest.-Tall trees and sea cliffs.

Materials Used.-Sticks and twigs.

Eggs.-Three or Four. Dull greenish-blue. Food.-Fish (especially eels), reptiles, watervoles, snails, and insects.

Voice.-A harsh, powerful cry, resembling the scream of the Peacock.

Chief Features.-Mostly nests in companies, called Heronries, but sometimes a single

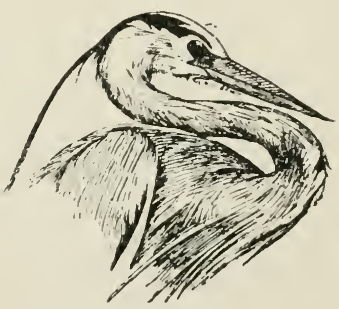

Fig. 16. Head of Heron. nest is quite isolated. At all times an interesting bird to watch. A splendid fisherman, being largely aided by long legs, wide wings, and dagger-like beak. A fine bird when well on the wing, the head and neck being held well forward, and the long legs straight out behind. A feature of the bird life of Broadland.

Plumage.-Bluish-black crest; slate-grey above; white forehead, cheeks, and neck, with streaks of bluish-grey, terminating with long white feathers, on the latter; greyish-white underneath; yellow bill. Length.-Thirty-six inches. 


\section{JACKDAW (Corvus monedula)}

Local Names.-Caw, Cawdaw, Daw, Jack, Kae," Kae-Wattie.

Haunt.-Woods, sea cliffs, church towers, and fields.

Nesting Period.-May and June.

Site of Nest.-Cliffs, hollow trees, old church towers, ruins, etc.

Materials Used.-Sticks, straw, dry grass, feathers, wool, leaves, etc. Often a large homestead.

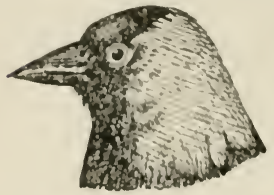

Fig. 17. Head of Jackdaw.

Eggs.-From Three to Six. Bluish-white, well spotted with ash and light and dark brown. Food.-Mice, young birds, reptiles, insects and their larva, earthworms, and offal.

Voice.-A shrill, high-pitched "kak, kak."

Chief Features.-An amusing pet, and can be taught to articulate in a wonderful way. Has increased enormously of recent years, and in many districts is regarded as a pest, driving away more useful birds. Often associates with Rooks and Starlings, and, like them, assiduously searches for grubs in fields and parks.

Plumage.-Black, with violet reflections, on crown and upper parts; grey, back of head and nape; white iris; dull black underneath. Length.-Fourteen inches.

\section{JAY (Garrulus glandarius)}

Local Names.-Blue-Winged Jay, Gay Pie, Jay-Pie, or Jay-Pict. Haunt.-Woods, copses, and plantations. Nesting Period.-End of April and early in May.

Site of Nest.-Tall trees and thick bushes. Materials Used.-Sticks, roots, and grass. Eggs.-Five or Six. Faint greyish-green,

thickly freckled all over with light brown.

Food.-Young birds and eggs, snails, earthworms, insects, and fruit.

Voice. - A harsh alarm-note, usually repeated three times.

Chief Features.-Another amusing pet, but a much more handsome bird than

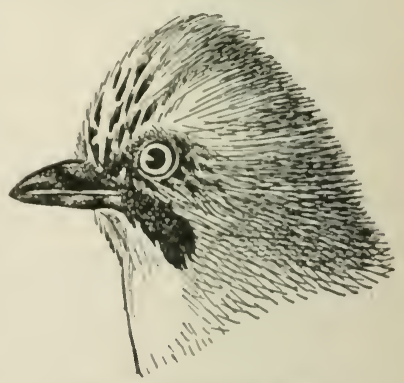

Fig. 18. Head of Jay.

its relative the Jackdaw. Can be taught to speak very plainly. Possesses a fluttering appearance on the wing, and when moving exhibits a dancing habit. When flying in company the Jay resorts to a follow-the-leader movement, the birds following one 


\section{JAY AND KESTREL}

another in a curious way. Blue feathers on wing used for making salmon flies.

Plumage.-Greyish-white crest, with black streaks; from the base of the beak it has a black moustache; reddish-grey is the general colour of the plumage, darker above; dingy-black primaries; velvet-black and white secondaries; rich chestnut inner tertiaries; the greater coverts and what is known as the winglet have black, white, and bright-blue bars; tail-coverts above and below white; bright-blue iris; black beak; darkbrown feet. Length.-Thirteen and a half inches.

\section{KESTREL (Tinnunculus alaudarius)}

Local Names.-Creshawk, Kastril, Keelie, Kestrel Hawk, Kistril, Mouse Falcon, Staengall or Steingall, Standgale, Stannel, Stannel Hawk, Stannel Hoverhawk, Stonegall, Windhover.

Haunt.-Woods, cliffs, downs, moors, and open fields.

Nesting Period.-April and May. Site of Nest.-Trees and cliffs. Materials Used. - Generally takes possession of the nest of a Magpie or Crow; if not, then uses sticks, twigs, etc.

Eggs.-Four or Five. Pale reddish brown, closely mottled with a darker shade.

Food. - Rats, mice, voles, birds, frogs, snails, and insects.

Voice.-A sharp ringing, half-laughing cry, and when nest is visited a plaintive, pleading note.

\section{Chief Features. -}

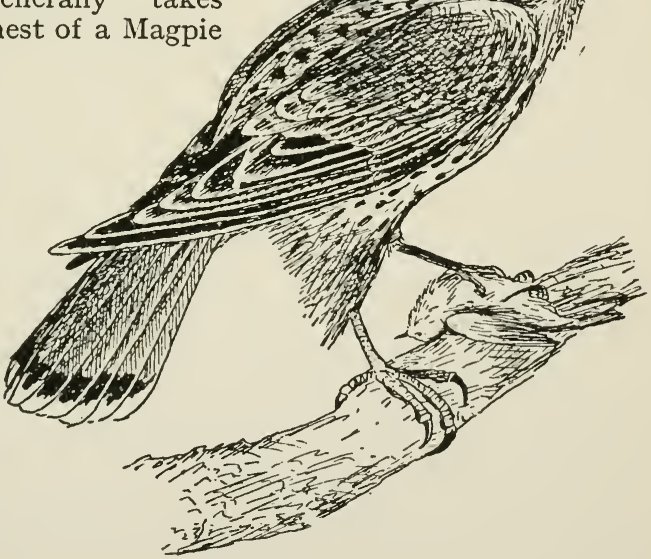

Fig. 19. Kestrel.

Easily distinguished from the Sparrow Hawk by plumage. The Kestrel is still much persecuted by gamekeepers, but does very little harm to game, and should be rigidly protected. 
Does not appear such a wild, dashing bird as the Sparrow Hawk, and has more regular hunting grounds.

Plumage.-Dark leaden-grey upper plumage, neck, and breast; light yellowish-red, with narrow, longitudinal, dark streaks on sides, wings, and under tail-coverts; blue beak; yellow cere and feet; brown irides; black claws. The female is light red above, as is also the tail, with transverse spots and bars of dark brown; underneath parts paler than her mate. Length.-Fifteen inches.

\section{KINGFISHER (Alcedo ispida)}

Local Names.-Halcyon, Slas-y-dorian.

Haunt.-Rivers, lakes, and streams.

Nesting Period.-March to July.

Site of Nest.-A hole in a bank, or wall, near water.

Materials Used.-Ejected bones of small fish. An untidy and dirty nest.

Eggs.-Six to Eight. Pure glossy white; .9 by .75 inch.

Food.-Fish, tadpoles, and water insects.

Voice.-A sharp, piercing note.

Chief Features.-Undoubtedly our most gorgeous British bird. Both sexes are equally beautiful. Possesses a strong flight and a watchful patience clelightful to notice. The powerful beak and short tail are worthy of note.

Plumage.-Azure-blue back; bluish-green head and wing-coverts, with azure-blue spots; a band of red under and behind the eyc, which passes into white, and underneath this a band of azuregreen; greenish-blue wings and tail; white throat; orange-red under parts. Length.-Seven and a half inches.

\section{KITE (Milvus ictinus)}

Local Names.-Crotched-Tailed Puttock, Fork-Tailed Glead, ForkTailed Kite, Glade, Glead, Gled, Greedy Glead, Greedy Kite. Puttock.

Haunt.-Woods and trees in lonely situations.

Nesting Period.-May.

Site of Nest.-A tall tree.

Materials Used.-Twigs and sticks, lined with wool, hair, etc.

Eggs.-Three. Dirty white, spotted with brown or reddish-brown, mostly at the larger end.

Food.-Leverets, rabbits, small mammals, poultry, young gamebirds, offal, and dead fish.

Voice.-A shrill cry, like "whew," and occasionally "keh-keh." Chief Features.-Nearly extinct as a British breeding bird, and yet 


\section{KITE AND LAPWING}

we learn that two or three hundred years ago it was a common sight to see this species hawking in the London streets. The deeply-forked tail is sufficient to identify this, the largest British bird of prey.

Plumage.-Above, reddish-brown; the feathers have pale edges, those of the head and neck long, tapering to a point, greyishwhite, with lengthwise streaks of brown; rust-colour underneath, with longitudinal brown streaks; reddish-orange tail, barred faintly with brown; horn-coloured beak; yellow irides, cere, and feet; black claws. The female is of a deeper brown above, and the feathers are pale at the extremity; white head and neck. Length.-Twenty-five inches.

\section{LAPIVING (Vanellus vulgaris)}

Local Names.-Bastard Plover, Common Lapwing, Crested Lapwing, French Pigeon, Green Lapwing, Green Plover, Lapwing Sandpiper, Peeseweep, Peewit, Piwipe, Plover, Puit, Teachet, Tee-Whaup, Tee-Wit, Teuchit, Teu-Fit, Tuet Flopwing, Tufit. Haunt.-Fields, meadows, marshes, etc.

Nesting Period.-March to June.

Site of Nest.-A depression in the ground.

Materials Used.-Bents, a few straws, dry grass, etc. Often none. Eggs.-Four. Olive-green, heavily blotched with black or blackish-brown. Very pointed at one end.

Food.-Insects and their larvæ, earthworms, slugs, etc.

Voice.-Two shrill notes resembling its local name of Peewit.

Chief Features.-Not only an interesting bird, but one of the most useful. An indisputable farmer's friend. A fine bird upon the wing as it wheels round and round, swooping and falling. A flock seen feeding and then put to flight has a very pleasing effect. Parent birds have a ruse of attempting to lure the intruder away from eggs or young.

Plumage.-Greenish-black on crown and crest; whitish on sides of neck, above metallic-green with purple reflections; black quills; white tail-feathers, with a broad band of black; bluish-black face, throat, and upper breast; white belly and axillaries; fawncoloured tail-coverts. Length.-Twelve inches. 


\section{LINNET (Linota cannabina)}

Local Names.-Blood Linnet, Brown Linnet, Common Linnet, Greater Redpoll, Grey Linnet (young), Linnet Finch, Lintie, Lintwhite, Red-Breasted Linnet, Red-Headed Finch, Red I,innet, Rose Linnet, Song Linnet, Whin Linnet, Yellow Linnet. Haunt.-Commons, fields, and waste lands.

Nesting Period.-April to June.

Site of Nest. - A furze, blackthorn, or whitethorn bush.

Materials Used.-Grass, with a hair lining. A neat structure.

Eggs.-Five. Bluish-white, lightly spotted with reddish-brown.

Food.-Weed seeds of various kinds, also buds in Winter. The young are probably fed on insects.

Voice.-A sweet and brilliant song when heard at its best, and when

a number of birds sing in chorus the effect is very pleasant. At other times the song is, to my mind, disappointing.

Chief Features.-One of our commonest Finches. Largely caught as a cage bird for pairing with a Canary. The male in his best nuptial plumage is a really handsome bird.

Plumage.-Crimson forehead and centre crown; brownish-grey on rest of head, nape, and neck sides; chestnut-brown mantle; blackish wing-feathers, with white on outer edges, which are conspicuous; dark-brown upper tail-coverts, margined with white; black tail-feathers, edged narrowly with white outermost and broadly on the inner webs; dull-white chin and throat, with greyish-brown stripes; crimson breast; dull-white belly; fawn-coloured flanks. During the Winter the crimson feathers are lost in a greyish colour. The female is altogether less conspicuous in colouring and possesses no crimson markings. Length.-Five inches and three-quarters.

\section{MAGPIE (Pica rustica)}

Local Names.-Chatterpie, Hagister, Madge, Mag, Maggie, Maggot, Miggy, Nanpie Pianet, Piet, Poyet, Pye Mag, Pyet.

Haunt.-Woods, and open fields where there are trees or tall bushes. Nesting Period.-March to May.

Site of Nest.- In tall trees, hedges, and bushes.

Materials Used.-Withered shrubs, thorny sticks, dry grass, fibrous roots, and clay. The nest is arched over, and there is a circular hole on one side.

Eggs.-Six to Eight. Pale bluish-green, or yellowish, closely freckled and spotted with olive-brown and ash.

Food.-Rats, mice, moles, birds, insects, worms, snails, and fruit. 


\section{HOUSE AND SAND MARTINS}

Voice.-A harsh chatter, but when kept as a pet readily learns to repeat words.

Chief Features.-Black and white plumage, long tail, and jerky, undulating flight are salient features. Very locally distributed. Plumage.-Velvet-black is the predominating colour, this being present on the head, throat, neck, and back; white on scapulars and under plumage; the tail is graduated, and, similar to the wings, black, with lustrous blue, green, and copper reflections; black beak and feet. Length._-Eighteen inches.

\section{MARTIN, HOUSE (Chelidon urbica)}

Local Names.-Eave Swallow, House Swallow, Martin Swallow, Martinet, Martlet, Meadow Martin, White-Rumped Swallow, Window Martin, Window Swallow.

Haunt.-The spacious air, houses, outbuildings, etc.

Nesting Period.-May to September.

Site of Nest.-Under the eaves of a house or other building, also on the face of rocks and cliffs.

Materials Used.-Clay and mud, cemented together with hair and fibres, lined with hay, straw, and feathers. Cup-shaped.

Eggs.-Four or Five. White; more oval than those of Sand Martin.

Food.-Insects.

Voice.-A pleasant alarm-note or call, and a pretty warble when the bird is on or near the nest.

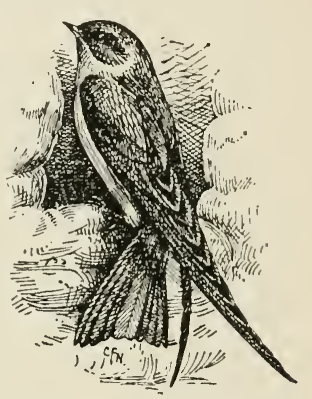

Fig. 2I. House Martin.

Chief Features.-Distinguished from the Swallow

by the white rump and more catapult-forked tail, and from the Sand Martin by larger size and blue-black head and back. An entirely beneficial bird. A Summer Migrant, arriving from its foreign Winter quarters about April 20.

Plumage.-Blue-black head, nape, and upper part of back; lower parts of back and underneath pure white. Downy feathers cover the feet and toes. Length.-Five and a half inches.

\section{MARTIN, SAND (Cotile riparia)}

Local Names.-Bank Martin, Bank Swallow, Bitter, Land Swallow, Pit Martin, River Swallow, Sand Swallow, Shore Bird, Witchuck. Haunt.-Sandpits, river banks, cliff-sides, etc.

Nesting Period.-May to July. Site of Nest.-The face of a sand-pit, cliff-side, or river bank. 
Materials Used.-At the end of the tunnel (which is hewn out by the bird itself) there is placed a collection of straw, dry grass, and a profusion of feathers.

Eggs.-Four to Six. White and pointed; .7 by.+8 inch.

Food.-Insects.

Voice.-A low, querulous note is uttered when the bird is on the wing, and a kind of scream when the bird gets excited.

Chief Features.-Nests in colonies, and the birds quite riddle a longfrequented nesting site with their ingenious tunnels. The small size and mouse-coloured back at once identify this species. Plumage.-Mouse-coloured uppermost, and on cheeks, with a broad bar on the breast; white on fore part of neck, belly, and under tail-coverts; legs and fect not downy as in House Martin, but naked, with exception of a few small feathers towards the hind toe; the somewhat short tail is forked. Length.-Five inches.

\section{MERGANSER, RED-BREASTED (Mergus serrator)}

Local Names.-Bar Drake, Diving Goose, Lesser Dun Diver, Lesser

Toothed Diver, Red-Breasted Goon, Red-Breasted Goosander,

Sawbill, Saw Neb, Sawyer.

Haunt.-Large sheets of water inland and the sea coast.

Nesting Period.-End of May to early in July.

Site of Nest.-On an island, or close to edge of a lake; under shelter

of a rock,or a depression in the ground; also among grass or scrub.

Materials Used.-Heather twigs, grass, and leaves, lined with down. Eggs.-Six to Nine, or more. Pale olive-grey; glossy.

Food.-Small fish and molluscs.

Voice.-A harsh "karr-karr."

Chief Features.-A handsome species, only known in the South as a Winter visitor, breeding north of the Clyde. A shy and wary bird, often disappearing under water when approached. So called because of chestnut on lower neck.

Plumage.-Red bill and irides; dark glossy green head, crest, and upper neck; white collar below, which is separated on the nape by a thin black line running to the back, which is also black; black on inner scapulars, outer ones white; white speculum with black bars; rump, flanks, and tail-coverts grey, and vermicular in character; pale chestnut lower neck with black streaks, a prominent tuft of white feathers with black edges on each side; white underneath; reddish-orange legs and fect. Length.-Twenty-four inches. The female is reddish-brown on head and neck, and is less gaudy and smaller. 


\section{MERLIN (Falco asalon)}

Local Names.-Blue Hawk, Sparrow Hawk, Stone Falcon (young). Haunt.-Moors, mountains, and cliffs and dunes near the sea. Nesting Period.-May and June.

Site of Nest.-Mountains, rocks, precipices, and on the ground. Materials Used.-A few heather twigs, scantily lined with dry grass or rootlets; often none.

Eggs.-Four. Reddish-brown, with mottling of a deeper shade. Food.-Blackbirds, fieldfares, partridges, skylarks, snipe, thrushes, and dunlins near the sea.

Voice.-A shrill chatter and a tremulous scream.

Chief Features.-Another Hawk which has disappeared from many of its former haunts. It is the smallest British Hawk. From its habit of sitting on a stone, or bare rock, it has acquired the name of Stone Falcon.

Plumage.-Greyish-blue above; reddish-yellow underneath, spotted with dark brown; tail barred with black; bluish beak, darker towards the tip; yellow cere; dark-brown iris; yellow feet; black claws. In the female the upper parts have a brownish tinge, while underneath they are yellowish-white. Length.From eleven to twelve inches.

\section{MOORHEN (Gallimula chloropus)}

Local Names.-Common Gallinule, Cuddy, Gallinule, Great Gallinule, Marsh Hen, Moat Hen, Moor Coot, More Hen, Water Hen. Haunt.-Rivers, lakes, and ponds. Nesting Period.-March to August. Site of Nest.-Among reeds or rushes near water, also in trees overhanging same.

MaterialsUsed.-Dry reeds and rushes, with a finer lining of sedges and dry grass.

Eggs.-Seven to Twelve. Reddishyellow, blotched or spotted with orange-brown.

Food.-Slugs, snails, worms, insects, and plants.

Voice.-A guttural "crr-o-ok."

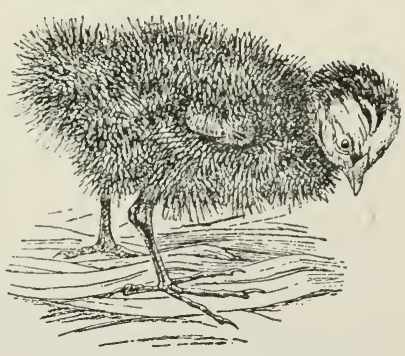

Fig. 22. Young Moorhen.

Chief Features.- - At once distinguished by dark plumage and red patch behind the bill. The young are sooty-black, and can swim the moment they emerge from the egg. The flight is rapid, but not long sustained. 
Plumage.-Bill yellow in front, and red at the base; red irides; dark olive-brown above; slaty-grey head, neck, and under parts, streaked with white on the flanks; under tail-coverts white; greenish-yellow legs, red above the tarsal joint. Length. -Thirteen inches. Contrary to most birds, the female is larger and brighter in plumage than her mate.

Local Name.-Philomel.

\section{NIGHTINGALE (Daulias luscinia)}

Haunt.-Woods, copses, and tangled hedgerows.

Nesting Period.-May and June.

Site of Nest.-Close to the ground in a thick bush, or among herbage. Materials Used. - Dry grass and oak leaves, lined with roots, vegetable down, etc. A deep nest.

Eggs.-Four or Five. Olive-brown or greenish-blue.

Food.-Insects and their larvæ.

Voice. - A written description is impossible. In spite of its remarkable beauty, many people mistake the song, especially during the day, when, to the unobservant, it is perhaps difficult to distinguish among the notes of other birds. When

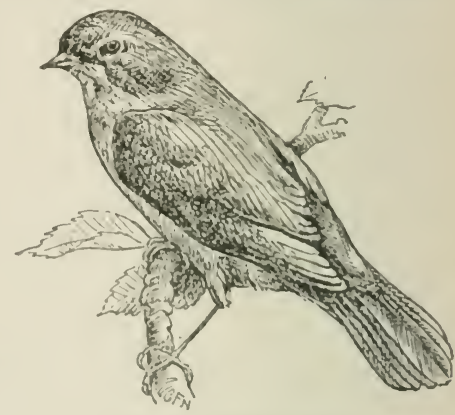

Fig. 23. Nightingale. it has young it also utters a weeping note and a harsh "krrrrr." Chief Features.- The Nightingale has long been regarded for its minstrelsy. It sings during the day as well as at night, but the song-period is short, and the bird rarely sings after June. It tends the young with great assiduity, and it is a pleasant sight to watch the young birds out of the nest being fed by their parents. A shy, recluse bird; the observer must exercise patience if he would stalk it successfully. A Summer Migrant, arriving about mid-April.

Plumage.-Chestnut-brown above; rufous tail ; greyish-white underneath; pale ash on flanks. Length.-Six inches and a quarter.

\section{NIGHTJAR (Caprimulgus europaus)}

Local Names.-Big Razor-Grinder, Churn Owl, Dog Hawk, Door Hawk, Dorr Hawk, European Goatsucker, Eve-Churr, Evejar, Fern Owl, Goat Owl, Goatsucker, Heave Jarr, Jar Owl, Moth- 
eater, Nightchar, Night-Churr, Night Crow, Night Hawk,

Nocturnal Goatsucker, Puckeridge, Wheel Bird.

Haunt.-Woods, and clearings near same.

Nesting Period.-End of May and June.

Site of Nest.- On the bare ground, sometimes hidden by bracken.

Materials Used.-None.

Eggs.-Two. White, marbled and mottled with grey of various shades, as well as black and faint lilac.

Oval in shape.

Food.-Large night-flying insects, such as the cockchafer and other beetles; also moths.

Voice.-A curious vibrating note, uttered while the bird is perched on the branch of a tree.

Chief Features.-A Summer Migrant, arriving from Africa and India towards the end of May. Nocturnal in habits, the parents squat on the ground during the day, coming out at nightfall. A remarkable bird upon the wing, and has

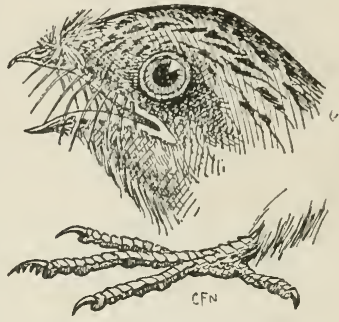

Fig. 24. Head and Foot of Nightjar.

the habit of bringing its wings right over its back. This causes a noise like a pistol shot. The Nightjar has a serrated claw, by means of which it can secure insects upon the wing. It also has a hairy mouth, short beak, and flat head.

Plumage.-Ash-grey, barred and spotted with brown, black, and chestnut; a large white patch on the inner web of the first three primaries, and tips of white on each side of the two outer tail-feathers. Length.-Ten inches and a quarter.

\section{NUTHATCH (Sitta cresia)}

Local Names.-European Nuthatch, Jar-Bird, Jobbin, Mud-Dabber, Mudstopper, Nutcracker, Nuthack, Nutjobber, Nut-Tapper, Woodcracker.

Haunt.-Woods, parks, and large gardens.

Nesting Period.-April to July.

Site of Nest.-A hole in a tree, which is plastered with mud so as to form just sufficient entrance for the bird.

Materials Used.-Dry leaves, chips of wood, flakes of bark, etc. Eggs.-Six or Seven. White, spotted with red-brown. They are very similar to those of the Great Tit. Food.-Insects, nuts, acorns, beech-mast, and berries.

Voice.-A "twit-whit" and "whit, whit, whit;" also "pip, pip, pip." The notes are varied, and often deceive the listener. In 
the early Spring the utterances of this bird cannot fail to

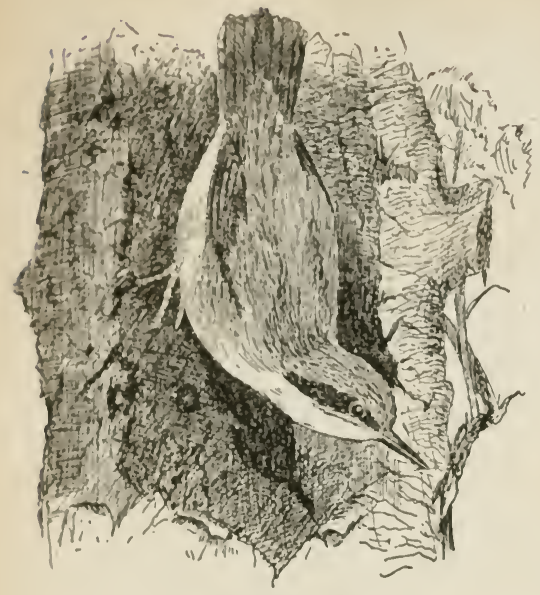

Fig. 25. Nuthatch. attract attention.

Chief Features.-The Nuthatch probably pairs for life, as male and female keep together all the year round. A common bird wherever there are suitable woods and parks, but requires looking for. Exclusively arboreal in habits. Comes down a tree head foremost. Note the strong beak and short tail. Inserts nuts in bark of trees during Winter, and extracts kernels as required. Does not split shell asunder, but scoops out contents by making a small hole in same way as the bank-vole.

Plumage.-Bluish-grey above; eye streak black; white cheeks and throat; buff breast and belly; chestnut-red flanks and lower tail-coverts; black on outer tail-feathers, with a little white near the extremity tipped with grey, the two central ones grey; bluish-black beak, white at the base of the lower mandible; light-brown feet. Length.-Five inches and a half.

\section{OSPREY (Pandion haliaëtus)}

Local Names.-Bald Buzzard, Eagle Fisher, Fishing Eagle, Fishing Hawk, Mullet-Hawk, Sea Eagle (young).

Haunt.-An island on a large sheet of water in the North, and also moors and the coast.

Nesting Period.-May and June.

Site of Nest.- Trees, and I have known the nest to be placed on the top of some old ruins.

Materials Used.-A pile of seaweed, grass, turf, sticks, etc. The same nest is resorted to each year after undergoing repair.

Eggs.-Three. Yellowish-white in ground colour, strongly marked with rich brown towards the larger end.

Food.-Fish, especially mullets.

Voice.-A harsh alarm-note; call-note likened to " $\mathrm{k}, \mathrm{k}, \mathrm{k}$."

Chief Features.-Belongs to the same order of birds as the Eagles, 


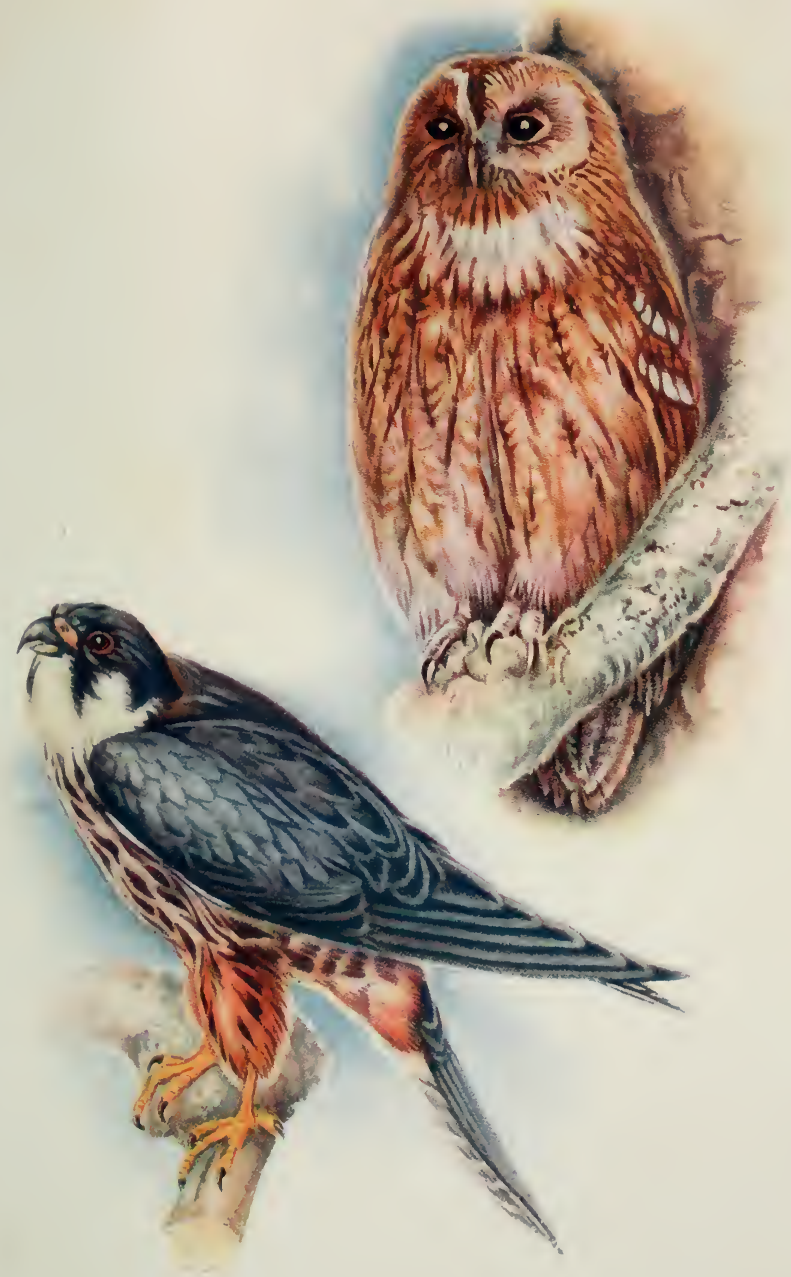

TaWN (OW (ahove), Hobry Falcon (below). 


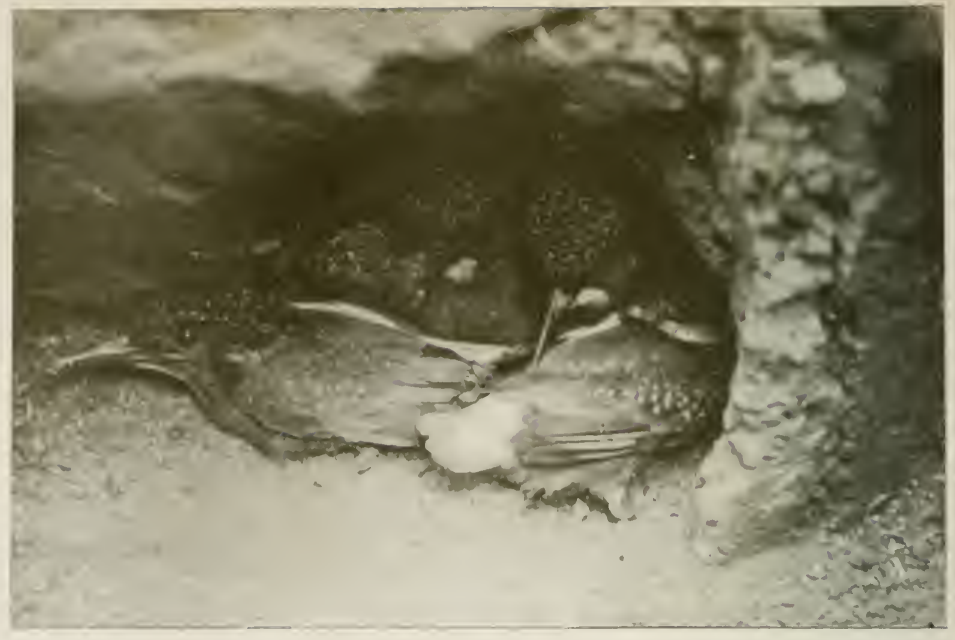

YOUNG KINGFISHERS.

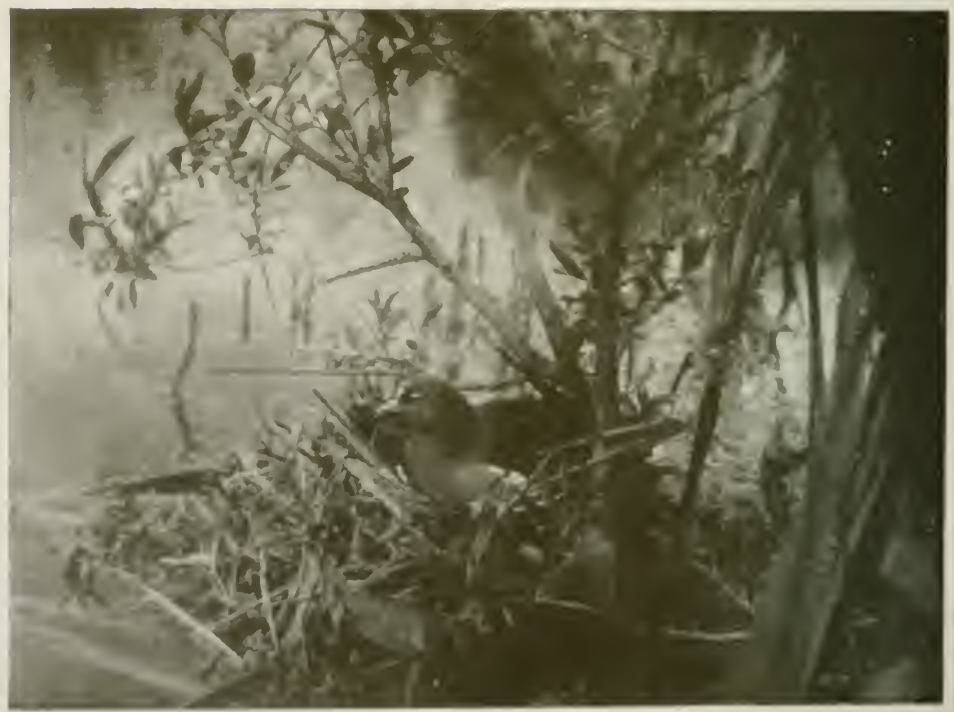


Falcons, and Hawks. This is not the species from which " osprey " feathers are obtained. A rare bird; majestic upon the wing, and captures its prey with much adroitness.

Plumage.-On the head the feathers are white, dark towards the centre; neck the same, with a blackish-brown streak extending in a downward direction; deep-brown upper plumage; white underneath, with a tinge of yellow, and arrow-like spots on breast; dusky bars on tail-feathers; dark-grey cere and beak; yellow iris. Length.-Twenty-four inches.

\section{OUZEL, RING (Turdus torquatus)}

Local Names.-Convoy, Flitterchack, Michaelmas Blackbird, Moor Blackbird, Mountain Blackbird, Mountain Ouzel, Phillip, Ring Blackbird, Ring Thrush, Rock Ouzel, Rong Starling, Stirlin, Tor Ouzel, Whistler, White-Throated Blackbird.

Haunt.-Moors, mountains, glens, ravines, rocks, etc.

Nesting Period.-End of April to June.

Site of Nest.-On a steep bank under grass or heath, or among moss;

in a clump of heather or in the fissure of a rock.

Materials Used.-Coarse and fine grass.

Eggs. - Four or Five. Light green in ground colour, handsomely blotched with ash, fawn, and brown.

Food.-Insects and their larvæ, slugs, snails, and probably wild moorland fruits.

Voice.-The song is somewhat like that of the Mistle Thrush, consisting of a few clear notes.

Chief Features.-Haunts solitary places far from habitations. It is like a Blackbird, with a white spot on the throat, but in habits, as well as in voice, resembles the Mistle Thrush. A Summer Migrant, arriving about the end of March or in early April.

Plumage. - The plumage generally is black, with white edges to the feathers; a large crescent-shaped spot of white on the throat. The female is greyer, and the white mark is not so pure white, and is narrower than in the male bird. Length.-Eleven inches.

\section{OWL, BARN (Strix flammea)}

Local Names.-Billy Wix, Cherubim, Church Owl, Cream-Coloured Owl, Gilli-Howlet, Hissing Owl, Hoolet, Howlet, Madge Howlett, Madge Owl, Mag Oolie, Roarer, Screech Owl, White Owl, Woolert, Yellow Owl.

Haunt.-Woods, farmsteads, old buildings, church towers, etc.

Site of Nest.- Holes of trees, in barns and other outbuildings, church towers, ivy-clad ruins, etc. 
Materials Used.-Decayed wood, ejected pellets, and cast-off feathers. Eggs.-Three or Four. White; pointed; 1.6 by 1.25 inch. Two eggs are laid first, and then a second clutch, eggs and young often being found in the nest together.

Food.-Rats, mice, moles, shrews, birds, fish, and beetles.

Voice.-Hisses, hoots, screams, and snores. Snaps the bill angrily. Chief Features. - The white and mottled plumage at once identifies this Owl. It has, like its relatives, a silent flight, and is, of course, nocturnal. Should be highly encouraged, as it is a distinctly useful species. Casts up, like other Owls, the indigestible portions of food in the form of pellets.

Plumage.-Yellowish-white beak; above it is tawny-yellow, variegated with brown, grey, and white; white on face and lower parts, with the margin feathers tipped with brown. Length.Fourteen inches.

Local Names.-None.

OWL, LITTLE (Athene noctua)

Haunt.-Woods.

Nesting Period.-Mid-April to mid-May.

Site of Nest.-Hollow trees, and seems to prefer in England a pollarded willow.

Materials Used.-None, excepting materials which accumulate as in case of other species.

Eggs.-Four to Six. White; oval; I.3 by 1.4 inch.

Food.-Mice, small birds, and large insects.

Voice.-Something like that of the Lapwing or Pcewit, but shriller. Seebohm compares it to "cuc-koo-vah'-ee, cuc-koo-vah'-ee."

Chief Features.-Introduced into this country by Charles Waterton in 1843 , and by several other naturalists since, this little species has increased its range of recent years, and is now rightly regarded as a British bird. The small size at once identifies it. It is diurnal as much as it is nocturnal.

Plumage.-Brown, streaked with white above; face white; under surface same colour, banded with brown; breast and abdomen streaked with brown, also under tail-coverts; yellow bill, with a green tinge; fect greyish-yellow; iris yellow. Length.Eleven and a half inches. Female a trifle smaller.

\section{OWL, LONG-EARED (Asio otus)}

Local Names.-Horn Owl, Howlet, Long-Horned Owl. Haunt.-Woods and parks.

Nesting Period.-March and April.

Site of Nest.-Most observers state that this Owl never builds a 


\section{SHORT-EARED AND TAWNY OWLS}

nest of its own, but appropriates the deserted nest of a Crow

Magpie, or Squirrel.

Materials Used.-See above.

Eggs.-Four or Five. White; oval in shape; 1.65 by 1.3 inch.

Food.-Voles, mice, sparrows, young birds, and insects.

Voice.-Call, "mew;" "yack! yack!" or a loud bark on the wing.

A snapping of the bill when defiant, and a hissing noise is made by the young.

Chief Features.-Distinguished by the long " ears," after which it has been named. Not so common as the Barn and Tawny Owls.

Plumage._Blackish beak; orange-yellow eyes; buff on upper parts, with mottlings of grey and brown, and dark-brown streaks; facial disk buff, greyish-black on margin and outer rim; warm buff and grey underneath, streaked with blackish and small transverse bars. Length.-Fifteen inches.

\section{OWL, SHORT-EARED (Asio brachyotus)}

Local Names.-Hawk Owl, Horned Oolert or Howlet, Marsh Owl, Mouse Hawk, Mouse Owl, Short-Horned Howlet, Short-Horned Owl, Woodcock Owl, Woodcock Pilot.

Haunt.-Fens, moors, heaths, and large fields.

Nesting Period.-April and May.

Site of Nest.-On the ground among sedge or heather.

Materials Used.-Hardly any. Perhaps a few sedge leaves or reeds. Eggs.-Four to Seven. White; oval in shape; 1.6 by 1.28 inch.

Very similar to those of the Long-Eared species.

Food.-Voles for the most part, also other small mammals and birds. Voice.-A harsh cry and a shrill scream; snaps beak violently when young are approached.

Chief Features.-Diurnal in its habits. Nests in the North; a Winter visitor only in the South. Appears in the Autumn about the same time as the Woodcock, hence names of Woodcock Owl and Pilot. Feather tufts on head less noticeable than in Long-Eared Owl.

Plumage.-Face whitish; beak black; iris yellow; small black feather tufts on head; blackish-brown circles round eyes; dusky-brown, with yellow edgings, above; dull-yellow inkbrown streaks underneath. Length.-Fifteen inches.

\section{OWI, TAWNY (Syrnium aluco)}

Local Names.-Black Owl, Brown Owl, Grey Owl, Hoot Owl, Howlet, Ivy Owl, Jenny Howlet, Jinny Oolet, 'Ollering Owl, Wood Owl.

Haunt.-Woods, commons, and parks. 
Nesting Period.-March and April, often later.

Site of Nest.-A hollow tree, or a deserted nest of a Crow, Magpie, Ring Dove, or Squirrel is used. Also in barns and outhouses. Materials Used.-Decayed chips of wood, and usual pellets and discarded feathers which accumulate in a tenanted haunt.

Eggs.-Three or Four. White; round; large; 1.8 by 1.52 inch.

Food.-Rabbits, rats, moles, mice, young birds, and, it is said, fish. Voice.-This is the species which utters the weird hooting noise at night. It is something like "hoo-hoo-hoo-oo-oo;" also "tu-whit, tu-whoo," the last named being shriller and not so mellow. A hunger-call resembles "ky-eck. yek."

Chief Features.-Distinguished by its mellow hoot. The commonest British Owl. Much persecuted by gamekeepers because of harm said to be perpetrated among young game birds. Fortunately protected on some estates, where the owners like to have these birds preserved.

Plumage.-Beak greyish-yellow; dusky-blue iris; above reddishbrown, marked and spotted in various shades of brown, black, and grey; on the scapulars and wing-coverts there are large spots of white; bars of dark and reddish-brown on primaries and tail-feathers; reddish-white underneath, with transverse brown bars and longitudinal dusky streaks; the legs are feathered right down to the claws. Length.--Sixteen inches.

\section{OYSTERCATCHER (Hamatopus ostralegus)}

Local Names.-Chalder, Chaldrick, Choldrick, Mussell-Picker, Olive, Oysterpicker, Pianet, Pie, Pied Oystercatcher, Scolder, Sea Magpie, Sea Pie, Shelder, Skelder-Drake,

Tirma, Trithcham.

Haunt.-The seashore and its immediate vicinity. Nesting Period.-May and beginning of June.

Site of Nest. - On rocks or rough shingle.

Materials Used. - Hardly any, excepting, perhaps, a few small stones or pieces of shell.

Eggs.-Three or Four. Yellowish, handsomely blotched with ash and blackish-brown.

Food.-Small shellfish, also shrimps, worms, and other creatures.

Voice.-A shrill cry, or piercing whistle, and also

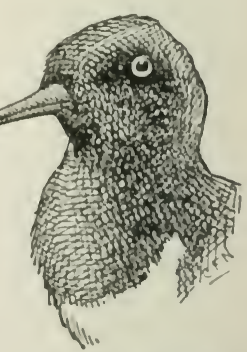

Fig. 26. Head of Oystercatcher.

shrill, rapid, rattling cries. Hett compares it to: "heep-heepheep," "kléép, kléép " (rapid and clamorous), or " quip, quip" (sharp and whiplike). On wing, "my fecl." 


\section{COMMON AND FRENCH PARTRIDGES}

Chief Features.-Easily identified by black and white plumage, long legs, and orange-yellow bill. One of the chief sentinels of the seashore, and an engaging bird at all times.

Plumage.-Jet black and pure white; orange-yellow" bill; crimson irides; purplish-pink legs and feet. Length.-Sixteen inches.

\section{PARTRIDGE (Perdix cinerea)}

Local Names.-Bird, Grey Partridge.

Haunt.-Fields, meadows, and hedgerows.

Nesting Period.-May and early June.

Site of Nest. - Under a hedge, or in a field or coppice.

Materials Used.-Dead leaves and grass. A flat structure.

Eggs.-Six to Twenty; twelve to sixteen is a good, average clutch.

Pale olive-brown or bluish-green.

Food.-Weed seeds of various kinds, also buds, green leaves, and

grain. The young are fed on insects and their larvæ.

Voice. - A harsh, complaining note, which may be compared to

"kirr-rr-ric" or "turwit." Alarm-note, "agick-agick."

Chief Features.-Mostly regarded because it is such a good sporting

bird. It is more of a wild bird than the Pheasant. Associates in coveys after nesting, these being made up of family parties. Horse-shoe patch on breast of male very characteristic. Plumage.-Grey and reddish-brown, speckled with black; horseshoe patch of chestnut on lower breast of male. Length.Twelve and a half inches.

\section{PARTRIDGE, RED-LEGGED (Caccabis rufa)}

Local Names.-French Partridge, Guernsey Partridge.

Haunt.-Fields, meadows, and coppices.

Nesting Period.-April to June.

Site of Nest.-Hedges and fields; sometimes on thatched buildings. Materials Used.-Dead leaves and grass.

Eggs.-Twelve to Eighteen. Cream-coloured, closely blotched and spotted with reddish or cinnamon-brown. Much larger than those of the Common Partridge.

Food. - Weed seeds, grass, clover, grain, insects, etc.

Voice. - Alarm - note, "a - shuck-a - shoe," "clik-clik-clik-ee-o." Call, " cocileke." Male, when pairing, cries "lasibio," " erchuck-er-choo," and " er-chuck-chuck-

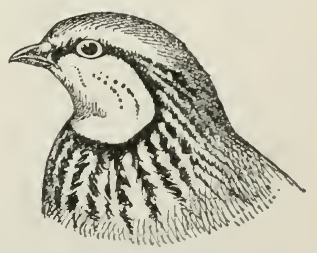

Fig. 27. Head of RedLegged Partridge.

erk." Other calls and cries are uttered in Summer and Winter. Chief Features.-One of the most curious features about this bird is 
its habit of laying eggs in the nests of the Common Partridge and Pheasant, in spite of the fact that it has its own nest to look after. It will temporarily desert the latter, but eventually returns and rears its brood. Not nearly so much liked as its British relative, being more of a wanderer, and not affording such good sport. A very handsome species.

Plumage.-White throat and cheeks, encircled with a band of black, which opens out on the breast and sides of neck in the form of spots and lines, with a little white spotted over same; reddishash above; flanks marked with crescent-shaped spots; rust-red near tail; black on centre, with white borders; bright-red orbits, beak, and fect. Length.-Thirteen and a half inches.

\section{PETREL, FORK-TAILED (Procellaria leucorrhoa)}

Local Names.-Bullock's Petrel, Leach's Petrel.

Haunt.-The sea coast and neighbourhood.

Nesting Period.-June.

Site of Nest.-Underneath stones and in holes of rocks and stone walls. Materials Used.-Very few. A few stalks and blades of grass, also lichen or moss.

Eggs.-One. White, with small red specks at one end; rough texture. Food.-Fish, offal, and various marine creatures.

I'oice.-A shrill chirp, and when on nest a double note somewhat like that of the Lapwing, " peur-wit, peur-wit."

Chief Features.-Breeds in the Outer Hebrides and on the Irish coast. Has a hesitating flight, skimming and half-circling. Sits very close when nesting. It is about the size of the Swift. Plumage.-Sooty-brown; upper tail-coverts white; some of under tail-coverts same colour; tail very forked; brown irides; duskyblack bill, legs, and feet. Length.-About seven inches.

\section{PETREL, FULMAR (Fulmarus glacialis)}

Local Names.-Malduck, Mallemoke, Malmarsh, Molly, Northern Fulmar.

Haunt.-The sea and its immediate vicinity.

Nesting Period.-End of May and early June.

Site of Nest.-Burrows in the earth and on sea cliffs.

Materials Used.-When any, a little dry grass.

Eggs.-One. White; rough and chalky; it has a strong odour, which alone is sufficient to identify it.

Food.-Offal, blubber, and meat.

Voice. $-\Lambda$ very silent species, and no account of the notes uttered seem to be recorded. 
Chief Features.-A very much larger species than either of its relatives. It much resembles the Gulls in flight, and is the best flier of the three species nesting in the British Isles.

Plumage.-Bill yellow; legs and feet grey; mantle and tail the same; dusky quills; white on head, neck, and under parts. Length.-Nineteen inches.

\section{PETREL, STORMY (Procellaria pelagica)}

Local Names.-Allamotti, Assilag, Common Storm Petrel, Gourder, Horn Finch, Little Peter, Little Petrel, Mitty, Mother Carey's

Chicken, Spency, Storm Finch, Witch.

Haunt.-The sea and its environs.

Nesting Period.-June to September.

Site of Nest.- In the burrow of a rabbit, under large stones, in holes of walls and cliffs.

Materials Used.-Only a few blades of grass and stalks.

Eggs.-One. White, sparingly marked with small brown spots; oval in shape.

Food.-Small fish, crustacea, mollusca, offal, etc.

Voice.-Hett describes the call as "kekerek-ee;" when nesting, a plaintive "weet; " when on the nest, a warbling " chatter."

Chief Features.-One of the smallest web-footed birds in the world, being no longer than a Sparrow. Excepting when it comes to land to breed, this, Jike its congeners, is entirely oceanic in its movements. It braves the roughest seas, and is met with many miles from land. The dark plumage and white tail-coverts at once identify it. It has long been made famous as Mother Carey's Chicken.

Plumage.-For the most part the plumage is black, with the exception of the base of tail-coverts and edges of wing-coverts, which are white; black bill and feet. Length.-Six inches.

\section{PHALAROPE, RED-NECKED (Phalaropus hyperboreus)}

Local Names.-Brown Phalarope, Coot-Foot, Half Nebb, RedNecked Coot-Foot, Red-Necked Lobe-Foot, Red Phalarope,

Red-Throated Phalarope, Scallop-Toe.

Haunt.-Islands in Scotland and the West of Ireland.

Nesting Period.-June.

Site of Nest.-A swampy and grassy situation, among a tuft of herbage. Materials Usèd.-A little dry grass.

Eggs.-Four. Pale buff or olive, thickly blotched, spotted, and speckled with varying shades of dark brown, and a few spots of light grey. 
Food.-Insects, worms, etc.

Voice.-A shrill and clear "weet" when nesting; call-note, "tirr." In Summer, "quet" or "quit;" also " chirra, chirra, chirra," and "kyow." "When rising and pursuing one another, "ketket-ket."

Chief Features.-Its comparative rarity as a British breeding bird. A fine swimmer and diver, and a rapid bird on the wing. On land it is also fleet of foot, being unlike many aquatic species in this respect.

Plumage.-The female is ash-grey on head, hind neck, and shoulders; dark grey, with a rufous mixture, above; on the wing a bar of white; chestnut neck; upper breast same colour as head; white under parts; black bill; greenish legs and feet. Length.Seven inches and three-quarters. The male is smaller, and is not so gaudily attired as his mate.

\section{PHEASANT (Phasianus colchicus)}

Local Names.-Cock-up, Longtail, Pheasie, Ring-Necked Pheasant. Haunt.-Woods, copses, plantations, and their vicinity.

Nesting Period.-April and May.

Site of Nest.-A hedge bottom, field, or coppice, and woods.

Materials Used.-Dead leaves and grass.

Eggs.-Seven to Fourteen, or more.

Food.-Seeds, acorns, berries, shoots, leaves, and insects.

Voice.-A startling " cock-up, cock-up, cock-up."

Chief Features.-Mostly esteemed as a game bird. Is rigidly preserved. Owing to its being shot, the species in this country has become polygamous, and does not pair as in its native wilds. The male is a really handsome bird, and battles are fought for possession of a female during the breeding season. The young can run about directly they emerge from the shell.

Plumage.-Green, blue, and yellow metallic reflections on head and neck; bare on sides of head, scarlet, spotted minutely with black; plumage generally marked with spots and bands of brown, red, purple, green, yellow, and black. The female is less gaudy, being light brown, and feathered on the sides of the head. Length.-Thirty-six inches.

\section{PIPIT, MEADOW (Anthus pratensis)}

Local Names.-Bog Lark, Cheeper, Chin Chacker, Grey Cheeper, Heather Cheeper, Heather Lintie, Hill Sparrow, Ling Bird, Meadow Lark, Meadow Titling, Moor Tite, Moor Titling, Moss Cheeper, Mossie, Peep, Pipit, Pipit Lark, Teetan, Teetick, 


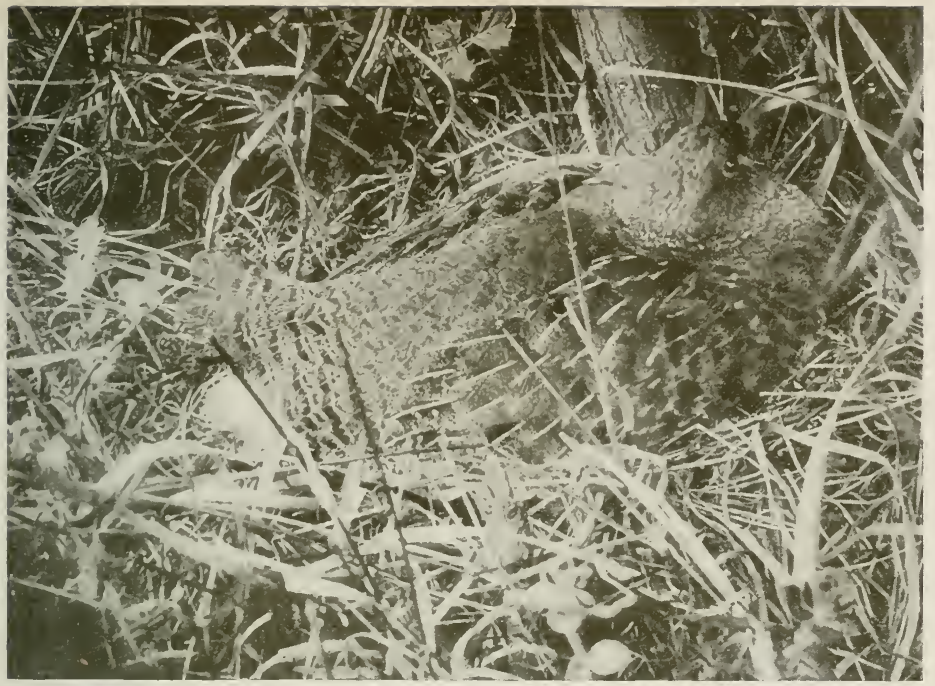

Common Partridge on Nest.

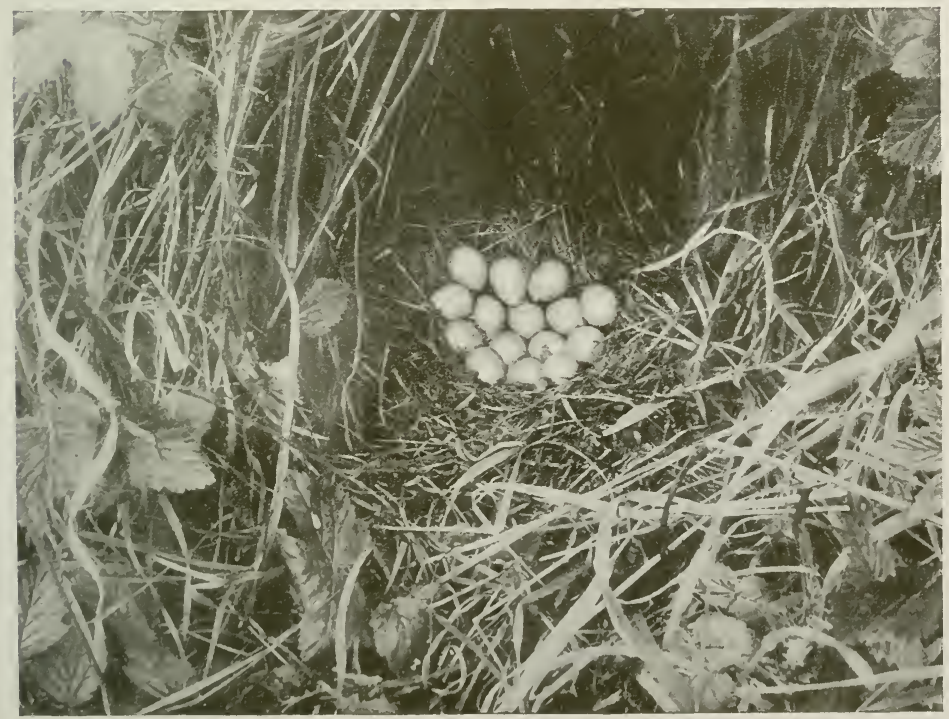

Nest and Eggs of Common Partringe. 


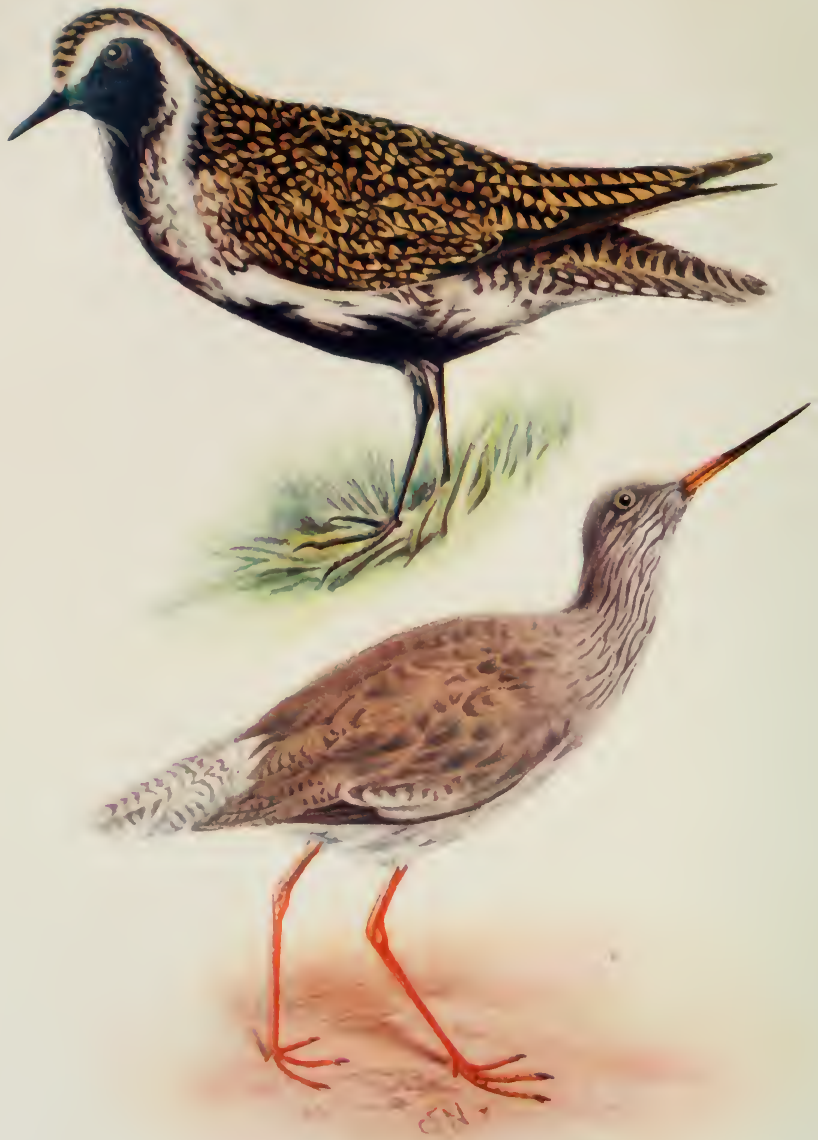

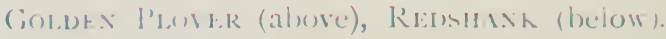


Teetling, Titling, Water Linnet, Wekeen. Often called the

Titlark, being confused by some with the Tree Pipit.

Haunt.-Moors, downs, and commons, also fields, sheepfolds, and seashore in Winter.

Nesting Period.-May and June.

Site of Nest.-On the ground, usually concealed among grasses, etc.

Materials Used. - Grass, moss, roots, lined with fine grass and hair.

Eggs. - Five or Six. Light and dark brown, or yellowish, closely mottled with darker tints.

Food. - Insects, including small beetles, and seeds.

Voice.-A tinkling song uttered in the air in a Lark-like way, but the notes are not to be compared to those of either the Skylark or Tree Pipit. The

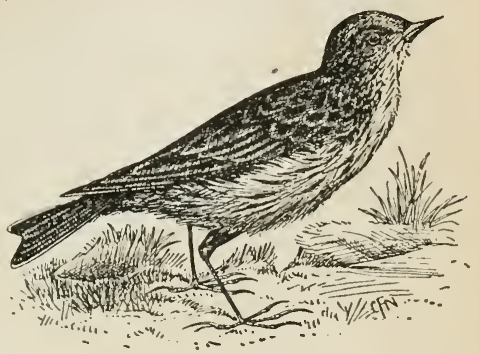

Fig. 28. Meadow Pipit. song, however, is typical of wild moorlands and breezy downlands. A shrill call-note is uttered, like " cheep-teep," and an alarm of "tu-wheet, tu-wheet." When flushed, a low, complaining "peep."

Chief Features. - This bird is the favourite foster-parent in Scotland of the Cuckoo. Large flocks come South in Winter and resort to fields, especially where there are sheepfolds. A common British bird, and, unlike the Tree Pipit, it is resident.

Plumage.-Above the colouring is ash, with an olive tinge, dark brown on centre of each feather; dull buffy-white underneath, profusely spotted with dull brown. The hind claw is longer than the toe, and slightly curved. Length.-Five inches and three-quarters.

\section{PIPIT, ROCK (Anthus obscurus)}

Local Names.-Dusky Lark, Field Lark, Rock Lark, Sea Lark, Sea Lintie, Sea Tit or Titling, Shore Lark, Shore Pipit.

Haunt.-The seashore and its immediate vicinity.

Nesting Period.-End of April onwards.

Site of Nest.-In a rabbit burrow, holes or ledges of sea cliffs, and under stones.

Materials Used.-Coarse bents, seaweed, and sometimes moss, lined with finer bents and perhaps horsehair.

Eggs.-Four or Five. Greenish, mottled with dusky-brown or dark cinereous. 
Food.-Marine insects, worms, and crustaceans; seeds in Winter.

Voice.-Alarm-note similar to that of the Mcadow Pipit. A pleasant little song is uttered in the air. It is of short duration, but very welcome because so few song-birds are found near the haunts of this Pipit.

Chief Features.-An active, engaging species, and fairly common wherever rocks are found. It is a resident British bird, and is always worth watching. The Meadow Pipit sometimes visits the shore and cliffs, but cannot be mistaken for this larger bird. Plumage.-Greenish-brown above, darker brown on the centre of each feather; over the eye a whitish streak; dull white underneath, with spots and streaks of dark brown. The hind claw is much curved, and is the same length as the toc. Length.- Six inches and a quarter.

\section{PIPIT, TREE (Anthus trivialis)}

Local Names.-Field Lark, Field Titling, Grasshopper Lark, Lesser Crested Lark, Lesser Field Lark, Lesser Tree Lark, Meadow Lark, Meadow Titling, Pipit, Pipit Lark, Short-Heeled Field Lark, Tit Lark, Tree Lark.

Haunt.-Hedgerows, banlis, and fields where there are trees, especially oak trees; also $f$ nd of perching on telegraph wires.

Nesting Period.-May and June.

Site of Nest.-On ground among grass, etc. ; often on a railway bank.

Miaterials Used.-Grass, roots, wool, moss, with a lining of finer grass and a little hair.

Eggs.-Four to Six. The ground colour varies from yellowish - white to purplish-red and rich chocolate, clouded, streaked, and blotched with darker tints. Quite distinct from those of the two other British species. Food.-Insects and their larvæ, and small

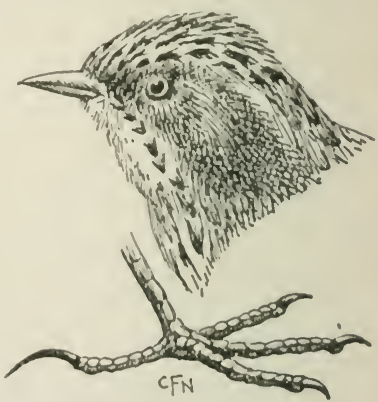

Fig. 29. Head and Foot of Tree Pipit. seeds.

Voice.-A very beautiful song is uttered whilst the bird is in the air, perched in a trec, or when on the ground. The full characteristic song is best listened to, however, when the Tree Pipit is going through one of its remarkable flights.

Chief Features. - The bird has the habit of perching at the top or on the outside branches of a tree, and from such a position flings itself into the air. It ascends to a height of several feet 


\section{GOLDEN AND KENTISH PLOVERS}

and then commences the descent. As it gets nearer the earth the song increases in volume and sweetness. Sometimes the bird returns to the place from which it started, but not invariably. A Summer Migrant, arriving about mid-April, it returns to the same haunt year after year.

Plumage.-Above ash-coloured, with an olive tinge, dark brown on centre of each feather; across the wing a double band of yellowish-white; white on the two outer feathers of the tail; dull white on throat and near eye; buff breast, with dark-brown elongated spots; lower parts dull white. Length.-Six inches.

\section{PLOVER, GOLDEN (Charadrius pluvialis)}

Local Names.-Black-Breasted Plover, Graen Plover, Grey Plover, Whistling Plover, Yellow Plover.

Haunt.-Moors, fields, mudflats, and the seashore.

Nesting Period.-May and June.

Site of Nest.-On the ground.

Materials Used.-A little grass or heath, but rarely any.

Eggs.-Generally Four. Yellowish, handsomely blotched with

blackish-brown. A long, pointed egg.

Food.-Insects, slugs, snails, worms, also tender parts of plants.

Voice.-Call, a flute-like "klee-wee;" also "kelleeee," or "kloveeee." In Spring, "tirr-pēē-yŏr." When a company utter notes in unison the effect is very pleasing.

Chief Features.-The change undergone in the dress, for the black under parts of Summer are changed in Winter to pure white. The name Golden Plover has been accorded because of the rich golden spots which decorate the upper parts. Nests in the North, but numbers come South in Winter, and often associate with the Lapwings.

Plumage.-Greyish-black upper parts, spotted with gamboge-yellow; over the eye is a line of white, which runs down the neck and reaches the flanks; black underneath. The under parts change to white after the Autumn moult, and the golden is of a brighter character than earlier in the year. Length.-Eleven inches.

\section{PLOVER, KENTISH (Egialitis cantiana)}

Local Name.-Kentish Dotterel.

Haunt.-The seashore, especially where there is shingle. Nesting Period.-May.

Site of Nest.-Among shingle, broken stones, or sand. Materials Used.-None.

Eggs.-Three or Four. Buff stone-colour, closely spotted, blotched, and scratched with blackish-brown and light inky-grey. 
Food.-Crustaceans, molluscs, sandworms, and insects.

Voice.-Call, "tirr, tirr, pit, pit, pwee, pwee," or a shrill "whit;" otherwise "pitwee " or "ptwee." Alarm, " tirr."

Chief Features.-A rare species, being restricted to two or three counties. It has been harried by collectors until it is almost on the verge of extinction as a nesting bird. Only with us during the Summer.

Plumage.- White forehead, eye stripe, cheeks, chin, and under parts; forehead above black, and a band of the same colour extends from base of bill through the eye, and a large spot of black on either side of breast; light brownish-red on head and nape; ash-brown above; white on two outer tail-feathers. The female lacks the black on the fore crown, brown on neck in place of black, and is generally of a duller character than her mate. Length.-Six inches and three-quarters.

\section{PLOVER, RINGED (Egialitis hiaticula)}

Local Names.-Alexandrine Plover, Dull-Willy, Land Laverock, Ringed Dotterel, Sand Lark, Sand Laverock, Sandy Loo, Shell Turner, Stone-Hatch, Stone Plover, Stone Runner, Wideawake. Haunt.-The seashore, mudflats, banks of rivers, and marshes.

Nesting Period.-April to June.

Site of Nest.-On the seashore among shingle or sand, or not far from the shore.

Materials Used.- None as a rule, but I have an interesting series of photographs showing that in many instances this bird does attempt to build quite a respectable homestead.

Eggs.-Four. Cream-colour, spotted and streaked with black; very pointed at one end.

Food.-Marine insects, worms, shrimps, etc.

Voice.-Call, a harsh "trr;" alarm-notes, "pen-y-et," also a short and mellow whistle like "too-it" or "too-o."

Chief Features.-One of the most entertaining birds of the seashore. Easily distinguished by engaging manner and black and white plumage. It is aptly named Wideawake.

Plumage.-Black forehead, lores, and gorget; white band across forehead; eye stripes, collar, and lower parts the same; light brown on nape and upper parts; white on outer tail-feathers; orange bill, orbits, and feet. The black collar of the female is not so prominent as in the male. Length.- Seven inches and three-quarters. 


\section{POCHARD (Fuligula ferina)}

Local Names.-Atteal Duck, Attle Duck, Black-Headed Wigeon,

Blue-Poker, Common Pochard, Dun Bird, Dun Cur, Dunker,

Great-Headed Wigeon, Poker, Red-Eyed Poker, Red-Headed

Pochard, Red-Headed Wigeon, Sandy-Headed Poker, Vare-

Headed Wigeon.

Haunt.-Fresh waters and the sea.

Nesting Period.-May.

Site of Nest.-The nest is well hidden among herbage near a lake, or some marshy situation.

Materials Used.-Dry grass and sedge, lined with bird's own down. Eggs.-Seven to Twelve. Pale whitish-buff, or greenish-buff.

Food.-Mostly vegetable matter, for which the bird is almost continually diving.

Voice.-Call, a low "whistle;" when alarmed or angered, a hoarse, croak-like " kr-kr-kr."

Chief Features.-A rare Duck nowadays, having disappeared from many of its former haunts. A very handsome species. Unlike the Wild Duck, which obtains its food on the surface of the water, the Pochard has to dive for its daily bread.

Plumage.-Head and neck chestnut-red; black breast and upper back; fine black and white frecklings on mantle; greyishwhite underneath; black tail-coverts; black bill, a blue band across the centre; red irides; bluish-grey legs and feet. The female is dull brown, and possesses a white chin. Length.Nineteen and a half inches.

\section{PTARMIGAN (Lagopus mutus)}

Local Names.-Common Ptarmigan, Ptarmichan, Rock Grouse, Snow Chick, White Game, White Grouse, White Partridge. Haunt.-Mountains and high hills in Scotland. Nesting Period.-May and June.

Site of Nest.-A depression in the ground on some mountain fastness. Materials Used.-As a rule, none whatever, but if any, a few heather twigs and dead blades of grass.

Eggs.-Seven to Ten. Yellowish, spotted and blotched with rich dark brown.

Food.-Berries and heath shoots in Summer, buds and leaves in Winter.

Voice.-A frog-like "croak," either low, or loud and prolonged. In Summer, on rising, a low "ug, ug."

Chief Features. - The high environments it inhabits, the three moults it undergoes, and the white plumage in Winter. 
Plumage.-This bird, like most Grouse, has three moults during the year. Its Winter dress is white, thus affording it much protection when the ground is snow-covered. In the Summer the feathers are dark-coloured, and as Autumn approaches they become grey, matching in a very wonderful manner the surroundings of its home at this season of the year. In a mild Winter more of the Autumn feathers are retained than during a severe Winter, when a pure-white plumage is so essential for protective purposes. Length.-Fifteen inches.

\section{PUFFIN (Fratercula arctica)}

Local Names.-Ailsa Cock, Ailsa Parrot, Bass-Cock, Bonger Cockandy, Coulterneb, Guldenhead, Knife-Bill, Marrot, Mullett, Pope, Sea Parrot, Shearwater, Skrabe, Tammy Norie, Tommy, Tommy Noddy, Tommy Norie, Tommy Tomnoddy, Willock (young).

Haunt.-Rocky sea cliffs and islands. Nesting Period.-May and June.

Site of Nest.-Holes in rocks, clefts, crannies, etc., often in a rabbit burrow, and in turf on summit of cliff.

Materials Used. - A few pieces of grass or roots, but usually none.

Eggs.-One. White when first laid, but soon becomes tinged with

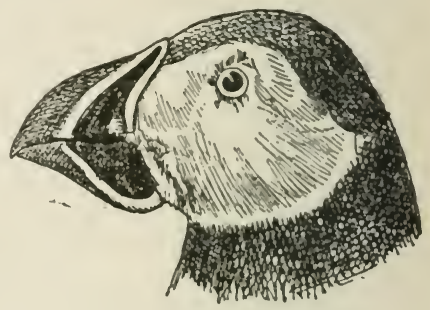

Fig. 30. Head of Puffin.

ash-colour. It is placed at the end of the burrow or hole.

Food.-Small fish for the most part.

Voice.-Call, "a-r-r" to "o-r-r," otherwise "orr-a-orr."

Chief Features.-The striking appearance which has resulted in it being called Sea Parrot. Very ludicrous in its habits, at once identified by the large beak and, in the breeding season, the brilliant-coloured sheath that envelops it.

Plumage.-Above, black; other parts white; the curious bill is bluish at the base, yellow in the centre, bright red at the top; orange-red legs and feet. Length.-Twelve inches.

\section{QUAIL (Coturnix communis)}

Local Name.-Wandering Quail.

Haunt.-Fields, uplands, etc., where there is a plentiful supply of herbage.

Nesting Period.-May and June. 


\section{QUAIL AND WATER RAIL}

Site of Nest.-In a depression of the ground, among grass, clover, corn, etc.; sometimes under cover of a hedgerow.

Materials Used.-Perhaps a few dead leaves and other materials, but practically none at all.

Eggs.-Seven to Ten, or more. Cream-coloured, clouded and mottled either with red-brown or spotted with dark brown.

Food.-Weed seeds, grain, buds, green leaves, etc.; the young are fed on small larvæ, including ants.

Voice.-The shrill, piping note is compared to the words "wet-mylips." It is often repeated with just a little variation.

Chief Features.-A rare British bird to-day, although at one time quite numerous. It is a Summer Migrant, arriving early in May from Northern Africa. It keeps very much to the ground. Plumage.-Black and reddish-brown on head, with three parallel, longitudinal streaks of a yellowish colour; ash-brown, with variegations of black and straw-colour, above; reddish-yellow neck, with a dusky-brown crescent of a double character; pale reddish-brown breast, with streaks of white; yellowish-brown bill and feet. The female is not so dark as her mate, and the double crescent on the neck is lacking. Length.-Eight inches.

\section{RAIL, WATER (Rallus aquaticus)}

Local Names.-Bilcock, Brook Ouzel, Brook-Runner, Grey-Skit, Runner, Shilty Cock, Skiddy Cock, Velvet Runner, War Cock. Haunt.-Reed patches, and among other aquatic herbage, such as marshes and osier plantations.

Nesting Period.-April to July.

Site of Nest.-On the ground in marshy situations.

Materials Used.-Dead aquatic herbage.

Eggs. - Six to Ten. They much resemble a small example of the

Corncrake, but paler. The spots also are fewer and fainter.

Food.-Frogs and tadpoles, spawn and fry of fish, and aquatic insects. Voice.-Hett gives the calls and cries as: Call, a shrill "crrrick," "cro-o-o-an" (called "sharming" in Norfolk), or a soft and clear " whit," heard after dusk; when near nest, "boh."

Chief Features.-A shy, skulking bird, probably often overlooked. Moves rapidly, but has a laboured and not long-sustained flight. Plumage. - Red bill; olive-brown hind neck and upper parts, the centre of each feather streaked with black; grey cheeks, neck, and breast; blackish flanks, with bars of white; brownish flesh-coloured legs and feet. The female is not so conspicuous in colouring as the male, and the wing-coverts are sometimes barred with white. Length.-Eleven inches and a half. 


\section{RAVEN (Corvus corax)}

Local Names.-Corbic, Corbie Crow, Corby, Great Corbie Crow. Haunt.-Mountains, precipitous sea cliffs, large woods, etc.

Nesting Period.-February to April.

Site of Nest.-Rocks, sea cliffs, and very tall trees.

Materials Used.-Sticks and roots, lined with wool and hair.

Eggs.-Four or Five. Light green, spotted and blotched with various shades of brown.

Food.-Hares, rabbits, rats, mice, moles, birds, dead animals, grain, grubs, worms, fruit, eggs, etc.

Voice.-A hoarse "kroack, kroack," also a deep "croak." When angered, "howk, howk," and when hungry, " ark-ark."

Chief Features.-Has disappeared from many of its former strongholds in Great Britain. Haunts solitary places. May be taught to articulate quite plainly. The largest British member of the Crow family. It has a wonderful distribution, being a citizen of the world.

Plumage.-Black, with purple reflections; black tail; iris with an inner circle of grey, and an outer one of ash-brown. Length.Twenty-five inches.

\section{RAZORBILI, (Alca torda)}

Local Names.-Alk, Auk, Bawkee, Black-Billed Auk (young), Common Awk, Falk, Helligag, Hiogga, Marrot, Murre, Oke, RazorBilled Auk, Scout, Sea Crow, Skort, Willock (young).

Haunt.-Rocky sea cliffs.

Nesting Period.-Mid-May onwards.

Site of Nest.-In a crevice or hole, on rocky sea cliffs.

Materials Used.-None.

Eggs. - One. White, or whitish, spotted and blotched with various shades of brown; ground colour tinged with light buff.

Food.-Small fish.

Voice.-Call, a croak, "hurray," and, when disturbed, a "grunt."

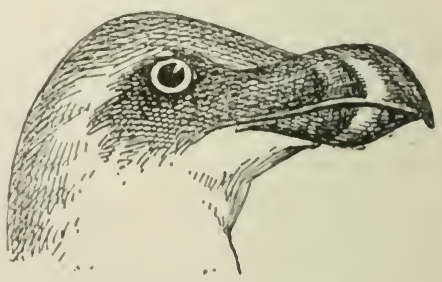

Fig. 3r. Head of Razorbill.

Chief Features. - The peculiar bill at once identifies this bird. It is the nearest living relative of the extinct Great Auk.

Plumage.-Greenish-black above; dark-brown throat; white under parts; black, axe-like beak, with a white, crescent-shaped mark across the deepest part. Length.-Seventeen inches. 


\section{ROBIN AND LESSER REDPOLL}

\section{REDBREAST (Erithacus rubecula)}

Local Names.-Bobbie, Bob or Bobrobin, Brow-Rhuddyn (Welsh),

Robin, Robin Redbreast, Robinet, Ruddock, Tommi-Liden.

Haunt.-Woods, lanes, commons, gardens, etc.

Nesting Period.-March to July, or later.

Site of Nest.-Hedge-banks, among ivy, in old cans, outhouses, etc.

Materials Used.-Moss, dead leaves, stalks of plants, with a neat lining of roots, wool, or hair.

Eggs.-Five or Six. White, freckled with light brown or red.

Food.-Worms, earwigs, butterflies, larvæ, spiders, daddy-long-legs, and scraps in Winter.

Voice.-A sweet but somewhat melancholy song. Also a curious "clicking" note, like "tit-tit-tit" (metallic), reminding one of the unwinding of a fisherman's reel. A weeping, monotonous note is uttered when nest is visited, and a curious hissing noise is made by the young when being fed.

Chief Features.-Probably the best-known and best-loved bird in the world. Very conscious of protection, and fond of companionship of mankind. The male and female are almost alike, but the young are spotted like young Thrushes until they acquire their well-known adult dress.

Plumage.-The plumage above is olive-brown; red forehead and breast, with grey edges; white belly. A great deal of error exists as to the female bird. It is a little smaller than the male, and is not attired so gaudily, otherwise the same. Length.-Five inches and threequarters.

\section{REDPOLL, LESSER (Linola rufescens)}

Local Names.-Chevvy Linnet, French Linnet, Lesser Red-Headed Finch, Lesser Redpole Linnet, Little Redpole Linnet, Pea Linnet, Redpole, Rose Linnet, Stone Redpole, Tweed. Haunt.-Woods and plantations. Very fond of birch woods.

Nesting Period.-May and June.

Site of Nest.-Hedges, bushes, and trees, especially firs.

Materials Used.-Small twigs, dry grass, and moss outside, lined with vegetable down, or wool and feathers.

Eggs.-Four or Five. Pale bluish-green, spotted with orangebrown or reddish.

Fig. 32. Lesser Redpoll. 
Food.-Insects in Summer; small seeds in Winter.

Voice.-A faint little song is uttered, but it must be carefully listened for or it will never be heard. It has a variety of calls and cries, as under: Call, "kreck, kreck, hayid;"." peewit;" when perching, "on-wee " or " honree;" on wing, a frequentlyuttered "twit" or " tiz-izik."

Chief Features.-Mostly nests in the North. Many come South in Winter. An active little species, always well worth watching. Plumage.-Black forehead, lores, and throat; deep-crimson crown; reddish-brown above, with dusky streaks; dusky wings!and tail, with pale edges of reddish-brown; prominent rose-red breast; white on belly and lower tail-coverts. The female is not so bright as the male. Length.-Five and a quarter inches.

\section{REDSHANK (Totanus calidris)}

Local Names.-Common Redshank, Gambet Sandpiper (young), Pool Snipe, Red-Leg, Red-Legged Horseman, Red-Legged Sandpiper, Red-Legged Yelper, Redshank Sandpiper, Sand Cock, Striated Sandpiper, Teuke, Took, Yelper.

Haunt.-Marshes, fens, tidal flats, and saltings.

Nesting Period.-April and May.

Site of Nest. - The nest is generally well hidden among grass or other herbage on swampy ground.

Materials Used.-Dry grass, a little moss, and perhaps heather twigs, but often only the surrounding herbage trodden down.

Eggs.-Usually Four. Cream-coloured, speckled and spotted with dark brown; very pointed at one end.

Food.-Marine worms, small crustaceans, insects, etc.

Voice.-A shrill, piercing "toodle-oodle-oodle-oodle." One of the chief sentinels of the seashore and mudflats.

Chief Features.-Long legs and beak; clear-cut wings; piercing cry. Feigns being wounded when it has eggs or young.

Plumage. - The Summer and Winter plumage must be given. The former is pale brown on upper parts, with close streaks and bars of umber; almost white secondaries; white rump, flecked with dusky; white tail-feathers, with blackish bars; white underneath, with umber streaks on neck and breast; orangered legs and feet. The Winter plumage consists of ash-coloured upper parts; white rump and under parts, sparingly streaked and spotted with grey on the breast and neck. Length.-Eleven inches; female a trifle larger than her mate. 


\section{REDSTART (Ruticilla phonicurus)}

Local Names.-Bran-Tail, Fire-Flirt, Fiery Bran-Tail, Fire-Tail, Redfiery Bram-Tail, Red-Tail, Whitecap, White-Fronted Redstart. Haunt.-Woods, parks, orchards, and large gardens.

Nesting Period.-May to July.

Site of Nest.-A hole or crevice in a tree or wall, in old sheds, etc. Materials Used.--Roots, moss, dry grass, lined with feathers and hair. Eggs.-Five or Six, but I have found Seven. Pale uniform bluishgreen; pointed at one end.

Food.-Grasshoppers, larvæ, beetles, butterflies, gnats, and spiders. Voice.-Call, a plaintive "weet," and a sharp "wee-tit-tit." A low, soft, and sweet song is also uttered.

Chief Features.-A shy species, and is doubtless often overlooked. Male can at once be distinguished by flame-coloured tailfeathers. It is a Summer Migrant, arriving about mid-April from Northern Africa.

Plumage. - The male has a white forehead; bluish-grey head and upper part of back; black throat; bright bay on breast, tailcoverts, and tail, but the two middle feathers are brown. The female is grey above, with a conspicuous tinge of red; inclining to whitish on throat and belly; pale red on breast, flanks, and under tail-coverts. Length.-Five and a quarter inches.

\section{ROOK (Corvus frugilegus)}

Local Names.-Bare-Faced Crow, White-Faced Crow. Haunt.-Woods, plantations, fields, and the seashore. Nesting Period.-March to May. Site of Nest.-Tall trees as a rule, but sometimes in high bushes. Materials Used. - Sticks and twigs, plastered with mud and clay, and lined with grass, straw, wool, etc. The old nest is repaired each year. Eggs.-Four or Five. Greenish, blotched and mottled with brownish-green. The variety and intensity of the markings vary.

Food.-Grubs of various kinds, including the destructive wireworm and larva of cockchafer, also earthworms and birds' eggs.

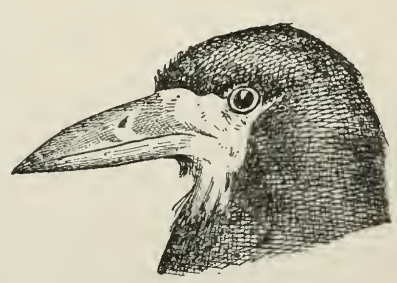

Fig. 33. Head of Rook.

Voice.-The well-known " caw," but other sounds are emitted which remind one sometimes of the Moorhen.

Chief Features.-Nests mostly in colonies, called Rookeries. Adult 
bird can be distinguished by bare patch of skin behind the beak. A sociable bird, and very unlike the Crow in this respect. Very sagacious, and waddles in a most engaging manner.

Plumage.-The plumage is generally supposed to be black, but the violet reflections, when the bird is examined closely, are very beautiful; there is a white scurf at the base of the beak and nostrils, this region being destitute of feathers; greyish-white iris. Length.-Eighteen inches.

\section{SANDPIPER, COMMON (Tringoïdes hypoleucus)}

Local Names.-Fiddler, Sand Lark, Sand Snipe, Sandy Laverock, Shad Bird, Spotted Sandpiper, Summer Snipe, Weet Weet, Willy Wicket.

Haunt.-Lonely and secluded streams, inland waters, and marshy places; also the seashore.

Nesting Period.-May and June.

Sile of Nest.-A small depression in the ground near water, generally well hidden; also in turnip- and corn-fields.

Materials Used.-A little sedge, moss, or dry grass; a very poor attempt is made to build a nest.

Eggs. - Four. Yellowish - white, blotched and spotted with brown and ash-grey.

Food.-Worms, insects, crustaceans, and small fry. Voice.-Call, "a-chuck, chuck, chuck;" on wing, a plaintive "weet-weet," or "weet, weet, killy leepic."

Chief Features.-A Summer Migrant, arriving from

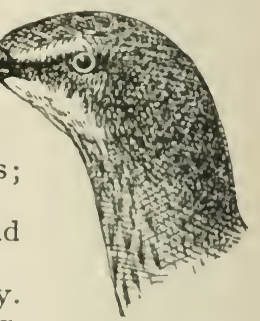

Fig. 34.

Head of Common Sandpiper.

Africa towards end of April, sometimes earlier. An active, engaging bird, distinguished by plump body, long beak and legs, and short tail.

Plumage.-Ash-brown above, with an olive gloss; white chin; pale ash on neck sides, and breast, streaked with dusky; white underneath and on extremities of outer tail-feathers. Length.Eight inches.

\section{SCOTER, COMMON (Edemia nigra)}

Local Names.-Black Diver, Black Duck, Black Scoter, Whilk. Haunt.-Seas and lakes.

Nesting Period.-May and June.

Site of Nest.-An island in the sea or some lake. The nest is usually hidden among grass or other herbage. 


\section{SHAG AND MANX SHEARWATER}

Materials Used.-Dead leaves, dry grass, and a few twigs, lined with down.

Eggs.-Six to Ten. Pale greyish-buff; shell smooth but not glossy. Food.-Shellfish.

Voice.-Call, a grating "kr-kr-kr" or "kre-kr-kre." Male to female, "tü-tü-tü-tü;" response of female, "re-re-re-re."

Chief Features.-A typical marine Duck, and, excepting when breeding, of oceanic habits. Glossy-black plumage of male very characteristic.

Plumage.-Glossy black above; orange on central ridge of upper mandible. Female, blackish-brown above; dark brown below. Length.-Twenty inches.

\section{SHAG (Phulacrocorax graculus)}

Local Names.-Common Shag, Crested Cormorant, Crested Scarf, Crested Shag (young), Green Cormorant, Green Scout, Isle of Wight Parson, Scarf, Skart.

Haunt.-Rocky islets and precipitous parts of the coast.

Nesting Period.-May and June.

Site of Nest.-Holes, crevices, and ledges of rocks and sea cliffs.

Materials Used.-Seaweed, turf, sticks, twigs, grass, and the like.

A large, untidy nest.

Eggs.-Three to Five. White when laid, but soon become soiled.

Food.-Fish.

Voice.-Call, a harsh, guttural "croak."

Chief Features.-Usually a very silent bird. Several pairs build close together. The green plumage is a distinguishing feature, and the Shag is not nearly so dark as its relative, the Cormorant. Plumage.-Bill black; yellow at the base of the under mandible; the skin about the gape black, and profusely studded with minute spots of yellow; emerald-green iris; dark green on crown, neck, and upper and under parts, with reflections of purple and bronze; black on wings and tail, legs, and feet; in Spring a crest on the forehead is prominent, but this is lost towards the end of May. Length.-Twenty-seven inches.

\section{SHEARWATER, MANX (Puffinus anglorum)}

Local Names.-Cuckee, Fachach, Lyne, Lyrie, Manx Lyre, Manx Petrel, Manx Puffin, Scraib, Scrapire, Shearwater Petrel, Skidden, Skrabe.

Haunt.-The sea and its environs.

Nesting Period.-May and June.

Site of Nest.-Holes under rocks or in the ground.

Materials Used.-A few dry stalks, or a little grass; often none at all. 


\section{BRITISH NESTING BIRDS}

Eggs.-One. White; of fine texture; about $2 \frac{1}{2}$ by $1 \frac{3}{4}$ inches.

Food.-Various kinds of marine creatures.

Voice.-Call, "kitty-coo-roo;" also " crew, cockathondon."

Chief Features. - Belongs to the Petrel family, and is a rare species.

It keeps to the broad expanse of ocean, and only comes to land

to breed. Nocturnal in habits. The name Shearwater is derived from the bird's habit of gliding along just above the surface of the sea.

Plumage.-Bill blackish; yellowish flesh-coloured legs and feet; sooty-black crown, nape, and upper parts; white under parts; greyish-brown on sides of neck. Length.-Fifteen inches.

\section{SHELDRAKF, COMMON (Tadorna cormuta)}

Local Names.-Bargander, Bargoose, Bay Duck, Burrow Duck, Common Shieldrake, Pirenet, Scale Drake, Shelldrake, Shellduck, Shieldrake, Skeel-duck, Skeeling Goose, Skelgoose, Sly Goose.

Haunt.-Sand dunes near the sea, also the seashore, saltings, etc. Nesting Period.-April to June.

Site of Nest.-Burrows in the sand, not made as a rule by the bird. Materials Used.-Sedge or grass, dry bents, a little moss, lined with soft down from the bird's own body.

Eggs.-Eight to Twelve, or more. White; about $2 \frac{1}{2}$ by 2 inches. Food.-Molluscs, crustaceans, marine plants, corn, and seeds.

Voice.-Call of male, a deep " korr, korr." Female, a loud " quack." Chief Features.-One of our most handsome British Ducks. Obtains its food by dabbling in shallow water or along the shore; it does not dive. A fine swimmer, and possesses a graceful attitude on land. Often uses the burrow of a rabbit as a suitable nesting site.

Plumage. - The male has a knob at the base of the bill which is lacking in the female, and this and the beak are bright red; dark glossy green on head and upper neck, with a collar of white, followed by a band of chestnut; white on wing-coverts; green speculum; black on scapulars, portion of secondaries, and primaries; white on rump, upper tail-coverts, and tail-feathers, with black tips on the latter; dark brown on centre of breast and belly, white on remaining under parts; pink legs and feet. Female duller than her mate. Length.-Twenty-six inches.

\section{SHOVELER (Spatula clypeata)}

Local Names.-Blue-Winged Shoveler, Blue-Winged Stint, Broad Bill, Broad-Billed Duck, Common Shoveler, Kertlutock, Kirktullock, Scopper-Bill, Shovel-Bill, Spoon-Bill, White Spoon-Bill. 


\section{SHOVELER AND RED-BACKED SHRIKE}

Haunt.-Inland fresh-water lakes and ponds.

Nesting Period.-May.

Site of Nest.-On the ground, but usually well hidden by herbage. Materials Used.-Sedge or dry grass, lined with down.

Eggs.-Eight to Twelve. Greenish-white; about 2 by $\mathrm{I} \frac{1}{2}$ inches.

Food.-Small fish, molluscs, frogs, aquatic insects, and plants.

Voice.-Call, "took, took." Female, "quack." When flying, "puck, puck."

Chief Features.-The spatulate and lead-coloured bill is sufficient to recognise this species. Many immigrant birds come to us in Winter, and may then visit low-lying parts of the coast. A fine swimmer, and a good flier. Shy and recluse in habits.

Plumage.-The broad-tipped bill is lead-colour; green on head and upper neck; white on lower neck and scapulars; dark brown on centre of back; pale blue on shoulders; white on greater wing-coverts; dark-brown secondaries; speculum green; blackish rump, upper and under tail-coverts, and tail-feathers; rich chestnut breast and belly; dark-brown freckled flanks on a paler ground; white vent; reddish-orange legs and feet. The female is brown, with light and dark mottlings. During the Summer, when the moult takes place, the male, like the Wild Duck, assumes the garb of the female. Length.-Twenty inches.

\section{SHRIKE, RED-BACKED (Lanius collurio)}

Local Names.-Butcher Bird, Cheeter, Cuckoo's Maid, Flasher, Flusher, French Magpie, Jack Baker, Lesser Butcher Bird, Murdering Pie, Nine Killer, Red-Back Butcher Bird, RedBacked Butcher Bird, Whiskey John.

Haunt.-Hedgerows and bushes.

Nesting Period.-May to July.

Site of Nest.-Hedges and bushes.

Materials Used.-Roots, moss, grass, lined with down or wool.

Eggs.-Four to Six. There are two common varieties, one being yellowish - white, marked at the larger end with light brown, and the other with ash-grey.

Food.-Mice, shrews, small birds, frogs, lizards, and large insects.

Voice.-A very silent bird. Hett gives the call

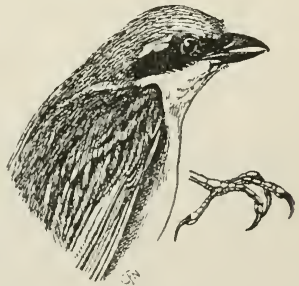

Fig. 35 .

Head and Foot of RedBacked Shrike. as " chack, chack," " churr-churr-chack."

Chief Features.-This well-named "Butcher Bird" has the habit of catching its prey and impaling same on thorns in the vicinity of the nest. It seems to kill far more food than it requires. 
Very often perches on telegraph wires. Has a jerky kind of movement. The male in his best attire is a most handsome bird, and may at once be identified by the dark frontal band of black. A Summer visitor from Africa, arriving in late April. Plumage.-Frontal band black, and also on lores and ear-coverts; grey on crown and nape; chestnut-brown mantle; dark-brown quills, with rufous edgings; grey tail-coverts; tail-feathers black, with the exception of the bases, which are white; rosebuff underneath; black bill and feet. Length.-Seven inches.

\section{SISKIN (Chrysometris spinus)}

Local Names.-Aberdevine, Barley Bird.

Haunt.-Pine forests.

Nesting Period.-April to July.

Site of Nest.-Fir trees, and, it is said, furze bushes.

Materials Used.-Moss, dry grass, roots, small fir or heather twigs, rabbit flick, and perhaps feathers.

Eggs.-Four or Five. Bluish, spotted with rust-colour, sometimes at one end and at others all over.

Food.-Small insects and seeds.

Voice.-Call, a metallic "keet" and oft-repeated "zit," also "pee-wee." In Spring male utters a sweet, musical song. Alarm, "chuck-a-chuck, keet."

Chief Features.-Resorts to lonely pine forests. Many come South in Winter. Easily distinguished by plumage. An active bird, resorting to Tit-like habits.

Plumage.-Black crown; behind eye a wide yellow streak; plumage variegated with dusky, grey, and various shades of green; dusky wings, with a greenish-yellow bar, a black one above, and a further onc across middle of tertiaries; dusky tail, greenishyellow at base and edge of inner web. Female not so bright, and black on head missing. Length.-Four and a half inches.

\section{SKUA, COMMON (Stercorarius catarrhactes)}

Local Names.-Bonxie, Brown Gull, Cornish Gannet, Great Skua, Port Egmont Heron, Skua Gull, Teaser, Tuliac.

Haunt.-Wild heaths, mountains, and the sea.

Nesting Period.-May and June.

Site of Nest.-On the ground.

Materials Used.-Moss, dry grass, and a few bits of ling.

Eggs.-One or Two. Dusky olive-brown, or greenish, with dark

blotches and rust-coloured spots.

Food.-Fish, young birds, carrion, etc.

Voice.-Call, a loud " ag-ag," "skua," or harsh "skua-h-h." 


\section{SKUA AND SKYLARK}

Chief Features.-Only found in the far North. A parasitic bird, subsisting largely on the labours of others. Exhibits a daring temper when molested.

Plumage.-Mottled-brown above; white on shafts of quills and tailfeathers; rufous-brown underneath; black bill, legs, and feet. Length.-Twenty-five inches.

\section{SKUA, RICHARDSON'S (Stercorarius crepidatus)}

Local Names.-Allan, Arctic Bird, Arctic Gull, Arctic Skua, Badock, Black-Toed Gull, Boatswain, Dirty-Allen, Dung Bird, DungHunter, Faceddar, Feaser, Labbe, Long-Tailed Labbe, ScoutieAllan, Scoutin-Aullen, Teaser.

Haunt.-Open moors, moorlands, and the sea.

Nesting Period.-May and June.

Site of Nest.-On the ground among heather.

Materials Used.-Very similar to last named.

Eggs.-Two. Greenish olive-brown, with dark-brown spots. Smaller

than those of the Common Skua.

Food.-Similar to the Common Skua.

Voice.-Call, a loud "keeow," "mee," and "mee-awk."

Chief Features.-A swift, gliding flight. A feathered pirate, robbing

Terns and other birds of fish, etc.

Plumage.-Dusky crown; white neck, cheeks, and under parts, tinged

with brown and yellow; otherwise dusky. Length.-Twenty inches.

\section{SKYLARK (Alauda arvensis)}

Local Names.-Alovette, Field Lark, Lark, Laverock, Lintwhite, Our Lady's Hen.

Haunt.-Fields, meadows, commons, moors, and downs.

Nesting Period.-April to July.

Site of Nest.-On the ground; often in the footprint of a cow, or other depression.

Materials Used.-Grass.

Eggs.-Four or Five. Yellowish or greyish, thickly freckled with dark brown.

Food.-Insects, sprouting corn, grass-blades, and seeds.

Voice.-Too well known to need description.

Chief Features.-Its love of the air and fascinating song-flights. Sings nearly the whole year through.

Plumage.-Above, three shades of brown, the darkest being along the shaft of each feather; over eye a faint streak of white; yellowish-white underneath, with a brown tinge; dark-brown spots on throat and neck sides, forming a gorget just above breast. Length.-Seven inches and a quarter. 


\section{SNIPE, COMMON (Gallinago calestis)}

Local Names.-Air Goat, Full Snipe, Heather-Bleat, Hoarse Gowk, Mire Snipe, Moor Lamb, Snite, Summer Lamb, Whole Snipe.

Haunt.-Marshy places, mudflats, etc. Nesting Period.-April or early May. Site of Nest.-On the ground, usually hidden among herbage.

Materials Used.-A few pieces of sedge or grass.

Eggs.-Four. Greenish-olive, blotched with dark brown.

Food.-Insects and worms.

Voice.-Various cries and calls, and a peculiar "bleating" sound, which is caused by the vibration of the wings and tail.

Chief Features.-The quick, erratic

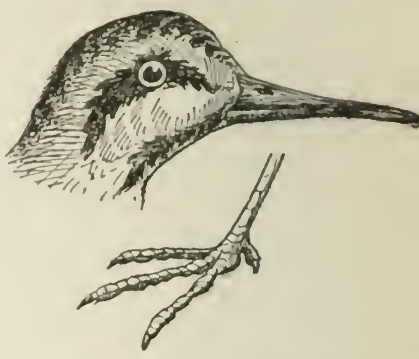

Fig. 36. Head"and Foot of Common Snipe.

flight, and "drumming" or "bleating" above referred to. Plumage.-Mottled-black and chestnut-brown; white and dusky bars on flanks; white underneath. Length.-Ten and a half inches.

\section{SPARROW, HEDGE (Accentor modularis)}

Local Names.-Billy, Black Wren, Blue Isaac, Blue Jamie, Blue Sparrow,'Blue Tom, Bush Sparrow, Creepie, Cuddy, Dick Dunnock,' Dicky, Doney, Dunnock, Dykesmavler, Dykie, Field Sparrow, Foolish Sparrow, Grosbeak, Hatcher, Hazock, Hedge Accentor, Hedge Bettie, Hedge Chanter, Hedge Chat, Hedge Chicken, Hedge Creeper, Hedge Mike, Hedge Warbler, Hempie, Muffitie, Phip, Pinnock, Shuffle-IVing, Titling, Whin Sparrow, Winter Fauvette.

Haunt.-Hedgerows and gardens.

Nesting Period.-March to July.

Site of Nest.-Hedges and bushes.

Materials Used.-Moss, twigs, grass, and wool, lined with hair. Eggs.-Four to Six. Bright blue.

Food.-Insects, small worms, seeds, etc.

Voice.-A pretty, continuous warble; little varied but cheery. Also a monotonous " cheep, cheep."

Chief Features. - A common British bird, distinguished by steel-grey and brown dress. Quite distinct from the House Sparrow.

Plumage.-Ash-colour crown, with brown streaks; bluish-grey neck 


\section{HOUSE AND TREE SPARROWS}

sides, throat, and breast; reddish-brown back and wings, with dark-brown streaks; buff-white breast and belly. Length.Five and a half inches.

\section{SPARROW, HOUSE (Passer domesticus)}

Local Names.-Brown Sparrow, Common Sparrow, Domestic Sparrow, Spagger, Sprug.

Haunt.-Found almost everywhere, in both town and country.

Nesting Period.-March to August, or earlier and later.

Site of Nest.-Houses and other buildings, trees, hedges, etc.

Materials Used.-Straw, hay, feathers, roots, grass, wool, etc. A large, untidy nest.

Eggs.-Five or Six. Dirty white, with a greenish or bluish tinge, blotched, spotted, speckled, and dashed, or either, with dark

brown, greyish-brown, etc. Most variable as to markings.

Food.-Insects, seeds, grain, and scraps.

Voice.-The well-known " chirp," and other calls and cries. I have twice heard this bird utter a pleasant song.

Chief Features.-Its remarkable abundance and wide distribution.

To be distinguished from the Tree Sparrow by ash-coloured

head and single white bar on the wings.

Plumage.-Black lores; over each eye a narrow white streak; ashgrey crown, nape, and lower part of back; chestnut near earcoverts; chestnut-brown back, with black streaks; brown wings, with bars of white on middle coverts; dull-brown tail; black throat and breast; white cheeks and neck sides; dullwhite belly. The female has the black on throat lacking, and the upper parts striated dusky-brown. Length.-Six inches.

\section{SPARROW, TREE (Passer montanus)}

Local Names.-French Sparrow, Mountain Sparrow.

Haunt.-Hedgerows, trees, woods, copses, etc.

Nesting Period.-April onwards.

Site of Nest.-Holes in old trees, buildings, crevices of rocks, etc.

Materials Used.-Similar to the House Sparrow.

Eggs.-Four or Five. Dirty white or light grey, marked with dark greyish or umber-brown.

Food.-Insects, weed seeds, etc.

Voice.-The notes are sharper, shriller, and more quickly uttered than those of the House Sparrow.

Chief Features.-A shyer bird than the last named. To be identified by chestnut head, black and white patches on sides, and double white bar on wings. 
Plımage.-Chestnut-brown crown and back of head; black lore, ear-coverts. and throat; white collar almost all round neck; upper parts as House Sparrow; two transverse white bars on wing. Length.-Five and a half inches.

\section{STARLING (Sturnus vulgaris)}

Local Names.-Black Felt, Brown Starling, Chepster, Jacob, Sheeprack, Sheep Stare, Sheep Starling, Shepster, Snow Bird, Solitary Thrush (young), Speckled Stare, Star Thrush (young), Stare.

Haunt.-Woods, trees, fields, and gardens. Nesting Period.-March to June.

Site of Nest.-Holes in trees, buildings, ivy-covered ruins, stacks, etc.

Materials Used. - Sticks, grass, straw, paper, feathers, wool, moss, etc. An untidy structure.

Eggs.-Four to Six. Pale blue; a trifle pointed.

Food. - Worms, larvæ, and scraps of various kinds; fond of fruit.

Voice.-A curious "chatter" and a characteristic "phe-ū." Introduces notes of other birds, especially that of the Lapwing.

Chief Features. - A gregarious species;

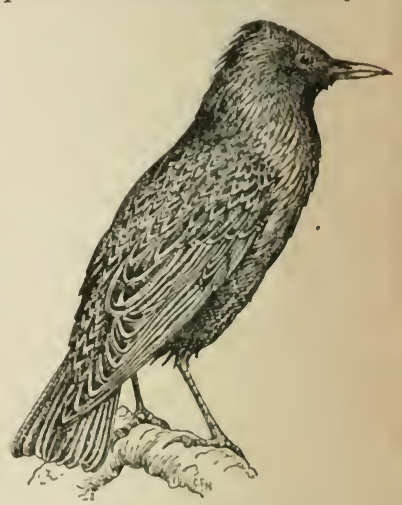

Fig. 37. Starling.

frecly mixes with Rooks and Jackdaws. Roosts in large companies. May be taught to imitate various calls and cries, and one I had uttered the note of the Cuckoo to perfection.

Plumage.-Black, with green and purple reflections; pale-buff tips on upper feathers; white edges to under tail-coverts; yellow beak; flesh-coloured feet, with brownish tinge. Female spotted on under parts as well as above; young ash-brown and unspotted. Length.-Eight and a half inches.

\section{STONECHAT (Pratincola rubicola)}

Local Names.-Blackcap, Black-Headed Bush-Chat, Blacky-Top, Blethering Tam, Chickstone, Furze Hacker, Moor Tite, Moor Titling, Stonechack, Stonechaker, Stonechatter, Stonechink,

Stonesmick, Stonesmith.

Haunt.-Furze commons and similar places.

Nesting Period.-End of April or early May.

Site of Nest.-At the bottom of a bush, or hidden among herbage. 


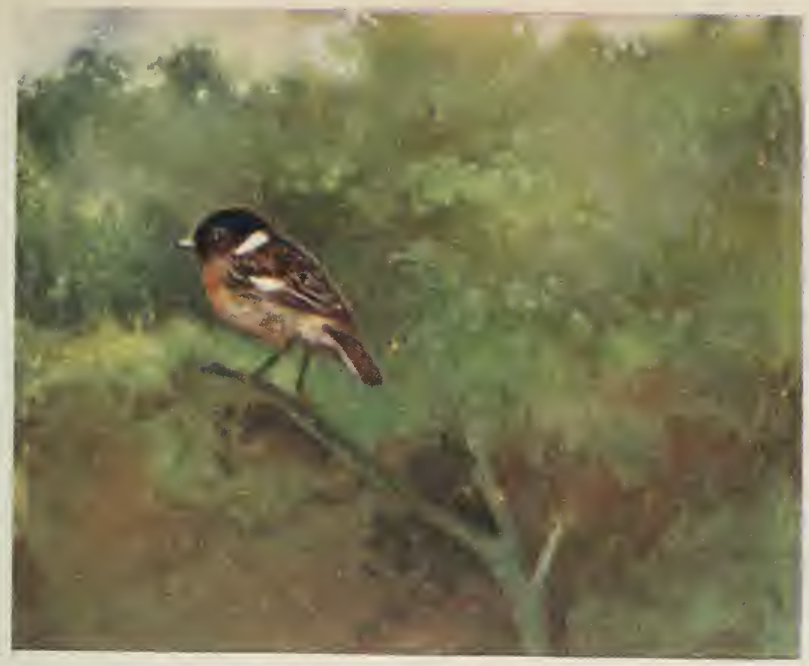

STONECHAT.

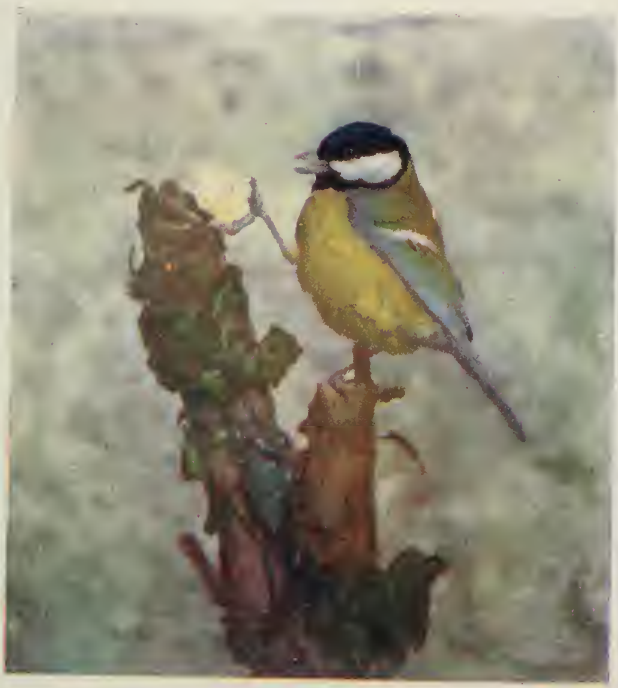

GREAT TIT 


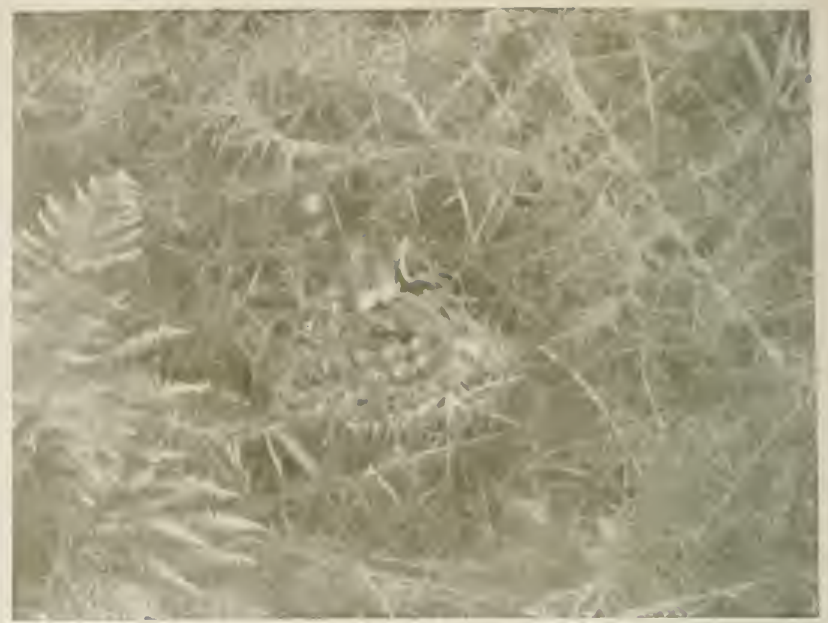

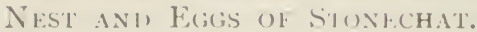

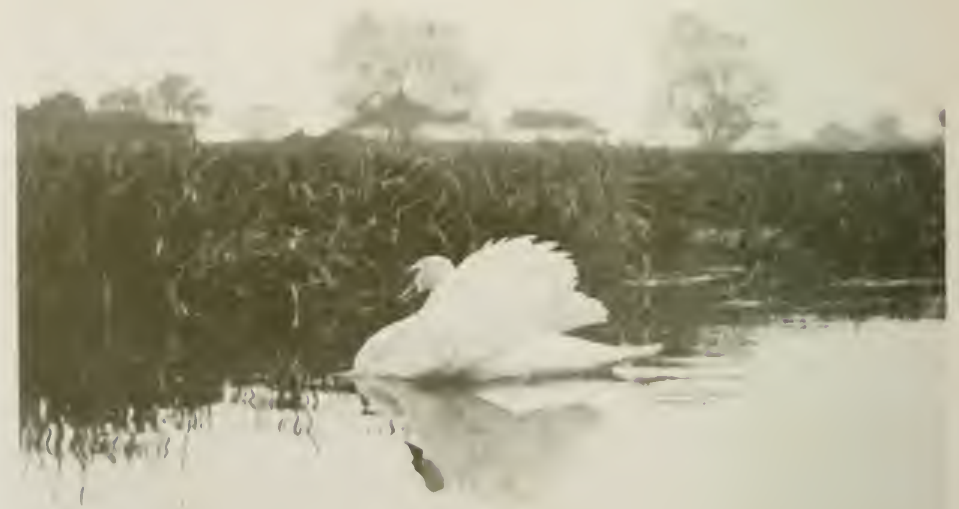


Materials Used.-Moss and dry grass, lined with finer grass, hair, and feathers.

Eggs.-Four to Six. Bluish-green, with a faint red circlet of spots at the larger end.

Food.-Insects.

Voice.-Call, "ütic, ütic," also "wee-chic-wee-chic, chic-chic-chic;" also a sweet and pleasant little song.

Chief Features.-The bird's habit of perching on the summit of a bush. A most restless species, and very agitated when it has young. Note the great difference between male and female.

Plumage.-Black head, throat, beak, and feet; white neck sides, tertial wing-coverts, and rump; bright chestnut-red breast, inclining to whitish on belly; feathers of back, wings, and tail black, with edges of reddish-brown. Female has the head and upper parts dusky-brown, with yellowish-red edges to the feathers; black throat, with small spots of white and reddish; not so much white in wings and tail; breast dull red. Length. -Five and a quarter inches.

\section{SWALLOW (Hirundo rustica)}

Local Names.-Barn Swallow, Chimney Swallow, House Swallow, Red-Fronted Swallow, Window Swallow.

Haunt.-The spacious air, buildings, surface of water, meadows, etc.

Nesting Period. - April to September.

Site of Nest. - Barns, quarries, chimneys, under bridges, etc.

Materials Used.-Mud, hay, and straw, lined with feathers.

Eggs. - Four to Six. White, marked with light and dark brown.

Food.-Insects.

Voice.-A shrill "pheet-a-pheet," and in Autumn " tiz-zit;" also utters a pretty song, both when perched and on the wing.

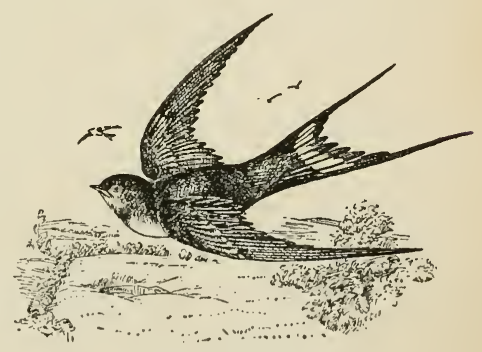

Fig. 38. Swallow.

Chief Features.-A Summer Migrant, arriving from Africa and India about mid-April. A wonderful bird upon the wing, swooping across meadows and rising and falling in a most remarkable way. Has long tail-feathers and chestnut-brown throat. Legs not feathered as in House Martin.

Piumage.-Chestnut-brown forehead and throat; black on upper parts and neck; sides with violet reflections; dull reddish- 
white underneath; long, forked tail. Female has not such a red forehead, and has less black on breast; under parts white, and outer tail-feathers shorter than in male. Length.-Seven and a half inches.

\section{SWAN, MUTE (Cygmus olor)}

Local Names.-Cygnet (young), Domestic Swan, Tame Swan. Haunt.-Rivers, lakes, ponds, etc.

Nesting Period.-March to May. Site of Nest.-Near water, often on an island. Materials Used.-A mass of rushes and reeds. Eggs.-Six to Nine. Greenish-white. The largest egg of any British bird.

Food.-Water plants, and probably small molluscs and insects.

Voice.-Call, a low, trumpet-like "maul," and a Goose-like " hiss." Chief Features.-Usually semi-domesticated, being in request for keeping on ornamental sheets of water. Very jealously guards nest, and not too good tempered.

Plumage.-Bill reddish-orange; nostrils, lores, nail, and basal tubercle black; pure-white plumage; black legs and feet. Male a trifle larger than female. Length.-Sixty inches.

\section{SIVIFT (Cypselus apus)}

Local Names.-Black Martin, Black Swallow, Black Swift, Cran, Cran Swallow, Davelin, Deviling, Devil Swallow, Devil's Screech, Jack Squealer, Martin Du, Screamer, Screech, Screech Martin, Skeer Devil, Skir Devil, Squealer, Swift Swallow.

Haunt.-Buildings, ruins, rocks, and, of course, the air.

Nesting Period.-End of May and June.

Site of Nest.-Under the roof of a building, in ruins, crevices of rocks, trees, etc.

Materials Used.-Hay, feathers, and similar materials, glued together with saliva.

Eggs.-Two or Three. White; 1.0 by .66 inch. Food.-Insects.

Voice.-A screaming "swee-ree-ee," and a shrill "pir-r-r."

Chief Features.-One of the latest Summer Migrants, not arriving until early May, and departing by August. A remarkable bird upon the wing, a company rushing

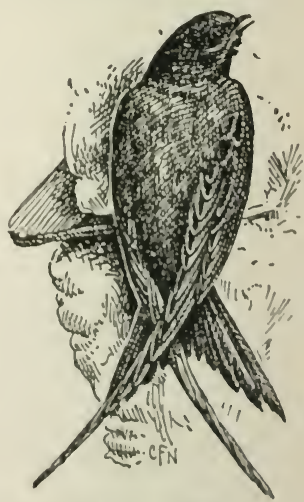

Fig. 39. Swift. through the air in concert together. Easily distinguished by 
dark plumage, and is in no way related to either the Swallow or Martin.

Plumage. - Sooty - brown; chin greyish - white; tarsi - feathered; black bill, feet, and claws. Length.-Seven and a half inches.

\section{TEAL, COMMON (Querquedula crecca)}

Local Name.-Summer Teal.

Haunt.-Lakes, etc.

Nesting Period.-May.

Site of Nest.-On the ground among aquatic herbage.

Materials Used.-Rushes, sedges, etc., lined with down.

Eggs.-Eight to Twelve. Buff-white, tinged with faint green.

Food.-Grain, aquatic plants, and insects.

Voice.-Call, " krink; " alarm, "knake."

Chief Features.-The smallest British Duck, and one of the most beautiful; docile and tame.

Plumage.-Blackish bill; chestnut crown, cheeks, neck, and throat; at back of eye and round same a glossy green patch with buff margins; black and white upper parts; black, green, and purple speculum, with yellowish-white tips; black rump and tail-coverts; brown tail-feathers; black spots on buff ground on front of neck; white breast and belly; brownish-grey legs and feet. Female mottled-brown, and not nearly so much purple on speculum, if at all. The Drake assumes the dress of the female in July, and keeps it until the following October. Length.-Fourteen and a half inches.

\section{TERN, ARCTIC (Sterna macrura)}

Local Names.-Pease Crow, White Daw.

Haunt.-The sea and seashore.

Nesting Period.-May and June.

Site of Nest.-Among sand, gravel, or shingle. Nests in colonies.

Materials Used.-Practically none.

Eggs.-Two or Three. Olive, buff, stone, greyish-brown, etc., in ground colour, marked with blackish-brown and grey.

Food.-Small fish.

Voice.—Call, "kik," or a prolonged "krr-ee," also a sharp "krrick." Chief Features.-All the Terns are characterised by their chaste form and appearance, and by their graceful flight. They are splendid fishermen, and capture their prey with great cleverness. Plumage.-Bill blood-red; legs and feet coral-red; black head and nape; pearl-grey mantle; white rump and tail; underneath the pearl-grey is paler. Length.-Fourteen and a half inches. 


\section{TERN, COMMON (Sterna fuviatilis)}

Local Names.-Big Mow, Great Tern, Gull Teaser, Kip, Kirmew,

Pease Crow, Picket, Picktarny, Pirr, Rippock, Rittock, Scobby

Scraye, Scrage, Sea Swallow, Sporre, Spurre, Tarney, Tarrack,

Tarret, Terrick, White Daw.

Haunt.-The sea, seashore, and inland waters.

Nesting Period.-May and June.

Site of Nest.- Same as Arctic Tern, and near inland waters.

Materials Used.-If any, dry bents.

Eggs.-Two or Three. Grey, yellowish-stone, or olive, blotched and spotted with dark brown and grey.

Food.-Small fish.

Voice.-Call, a sharp and angry " pirre," or a sharp " krrick."

Chief Features.-Found further South than the last named, and is not so slimly built. Dull white underneath instead of pearlgrey, and beak is tipped with coral-red instead of blood-red.

Plumage.-Orange-red bill, legs, and feet; plumage generally same as Arctic Tern, but lower parts more whitish. Length.-Fourteen and a quarter inches.

\section{TERN, LESSER (Sterna minuta)}

Local Names.-Chit-Perl, Lesser Sea Swallow, Little Mow, Little Tern, Pease Crow, Rickel Bird, Skerrek.

Haunt.-The sea and seashore.

Nesting Period.-June.

Site of Nest.-Same as Arctic Tern.

Materials Used.-None.

Eggs.-Three or Four. Yellowish-white, blotched with dark brown and ash-grey.

Food.-Small fish.

Voice.-Call, a sharp " pirre," a shrill "krrick," and "kiriree." In Autumn, "chit."

Chief Features.-This, the smallest British Tern, and the Roseate, are the two rarest nesting among us.

Plumage.-Orange-yellow beak, with black tip; orange legs and feet; black crown and nape; white forehead, and stripe over eye same colour; pearl-grey mantle; white tail and under parts. Length.-Eight inches.

TERN, ROSEATE (Sterna dougalli)

Local Names.-Pease Crow, Pirate.

Haunt.-The sea and seashore.

Nesting Period.-May and June. 
Site of Nest.-Among sand or shingle.

Materials Used.-None.

Eggs.-Two or Three. Yellowish, spotted with dark brown and ash; markings not so bold, but greater in number, than in others. Food.-Small fish.

Voice.-Call, "krr-ee," and a harsh " crake."

Chief Features.-The rosy under parts account for the name of Roseate; a rare British bird.

Plumage.-Bill black, and during breeding season orange-red at base; red legs and feet; head and upper parts resemble those of Arctic and Common Terns, with exception that it has paler pearl-grey mantle; under parts white, suffused with rose. Length.-Fifteen inches and a quarter.

\section{TERN, SANDWICH (Sterna cantiaca)}

Local Names.-Pease Crow, Surf Tern.

Haunt.-The sea and seashore.

Nesting Period.-May and June.

Site of Nest.-Among sand, shingle, etc.

Materials Used.-If any, dry bents.

Eggs.-Two to Four. White, marked with dark brown and ash.

Food.-Small fish.

Voice.-Call, a hoarse and grating " kirkitt," also " krrick."

Chief Features.-The largest British Tern; not nearly so graceful on the wing as its congeners. Easily identified by greater size.

Plumage.-Black bill and feet; black on top part of head; pearlgrey mantle; white rump, tail, throat, and underneath; breast has a rose tint. Length.-Sixteen inches.

\section{THRUSH, MISTLE (Turdus viscivorus)}

Local Names.-Bell Throstle, Bull Thrush, Feltie, Fulfar, Grey Thrush, Heelin (Highland), Holm Screech, Holm Thrush, Jercock, Misseler, Missell Bird, Misseltoe Thrush, Poyet, Screaming Thrush, Screech, Screech Thrush, Shreitch, Shrike-Cock, Shrite, Skirl-Cock, Skrietch Thrush, Storm-Cock, Thrice-Cock, Yellow Fulfar.

Haunt.-Woods, copses, parks, orchards, and large gardens.

Nesting Period.-February to April.

Site of Nest.-The fork of a tree.

Materials Used.-Grass, fine straw, moss, lichen, woven together with clay, and lined with fine fibres and grass.

Eggs.-Four or Five. Bluish-white, spotted with chestnut and clove-brown. 
Food.-Earthworms, snails, grubs, fruit, and berries.

Voice.-A loud song is uttered early in the year, but the notes are not so rich nor so variable as those of the Song Thrush. Call, a twittering " jis-rrr," and a harsh and grating "tir-tic-tur."

Chief Features.-A very early breeder, having young before most other birds have commenced to nest. A larger and bolderlooking species than the Song Thrush.

Plumage.-Ash-brown above; white underneath, with a yellow tinge and many spots of black; white on under wing-coverts; the three lateral tail-feathers tipped with greyish-white. Length.Eleven inches.

\section{THRUSH, SONG (Turdus musicus)}

Local Names.-Dirsh, Grey Bird, Mavis, Mavish, Throstle, Thrusher, Whistling Dick.

Haunt.-Woods, copses, plantations, hedgerows, gardens, etc.

Nesting Period.-March to July.

Site of Nest.-Hedges, bushes, trees, shrubs, etc.

Materials Used.-Moss, dry grass, and twigs, plastered inside with mud and rotten wood.

Eggs.-Four or Five. Bright blue, spotted with black or dark brown. Food.-Earthworms, snails, grubs, insects, slugs, and berries.

Voice.-Ranks high among British song birds, the notes being rich, flute-like, and of remarkable variety. Song has been likened to: "go-it, go-it, stick-to-it, stick-to-it, you'll-do-it, you'll-doit." First uttered early in the year, often all through Winter. Chief Features. - A handsome and one of our commonest resident birds. Many from the North visit the South during Winter. Chiefly regarded for its beautiful song.

Plumage.--Olive-brown above; throat white in middle; neck, sides, and underneath ochre-yellow, with dark-brown spots; pale orange-yellow on under wing-coverts. Male is smaller than female. Length.-Nine inches.

\section{TIT, BEARDED (Panurus biamicus)}

Local Names.-Bearded Pinnock and Reedling, Least Butcher Bird,

Pinnock, Reed Pheasant.

Haunt.-Marshy places luxuriant with reeds.

Nesting Period.-April to July.

Site of Nest.-On the ground among herbage.

Materials Used.-Dry grass, dead leaves, pieces of reed, with a fine grass lining and reed flowers.

Eggs.-Five to Seven. White, freckled with brown, streaked and speckled with dark brown. 


\section{BLUE AND COAL TITS}

Food.-Insects and small molluscs; reed seeds, etc., in Winter.

Voice.-A metallic note like "ping, ping." May be imitated by chinking two pennies together. Alarm-note, "hear, hear."

Chief Features.-Mostly restricted to the Norfolk broads. Worth watching at all times, the antics of the birds as they cling to the reeds being very engaging. A shy, recluse species.

Plumage.-Head bluish-grey; a tuft of pendent black feathers between the bill and eye, which is prolonged into a sort of pointed moustache; greyish-white on neck and throat; white breast and belly, with yellow and pink tinge; above light orange-brown; wings variegated with red, white, and black; a long orange-brown tail, outer feathers variegated with black and white. The female has moustache similar colour to cheek; grey on head missing. Length.-Six and a half inches.

\section{TIT, BLUE (Parus caruleus)}

Local Names.-Allecampain, Billy-Biter, Bluebonnet, Bluecap, Blue Mope, Blue Oxeye, Blue Tom Tit, Blue Whaup, Blue Yaup, Bottle Tit, Hickmall, Hickwall, Jerrybo, Nun, Pick-Cheese, Pinchem, Stonechat, Titmall, Tomtit, Tunnock.

Haunt.-Woods, copses, trees, and gardens.

Nesting Period.-April to June.

Site of Nest.-Holes of trees, walls, banks, and many other curious places, such as letter-boxes and lamp-posts.

Materials Used.-Moss and grass, lined with feathers, hair, and wool. Eggs.-Seven to Twelve. White, marked with faint red-brown, usually at the larger end.

Food.-Insects and their larvæ, and in Winter buds and small seeds. Voice.-A vociferous bird at all times, but the notes are difficult to write down. A shivering little song of a pleasant description. Call, " ping, ping, si, si, si."

Chief Features. - Pretty dress, active habits, and cheery notes. One of our commonest British Tits.

Plumage.-Blue crown, encircled with white; white cheeks, with dark-blue borders; olive-green back; bluish wings and tail; white tips on greater coverts and secondaries; yellow breast and belly, with a dark-blue line. Length.-Four and a half inches.

\section{TIT, COAL (Parus britannicus)}

Local Names.-Blackcap, Black Oxeye, British Cole Tit, Caley Tit, Coalhead, Cole Mouse, Cole Tit, Tomtit.

Haunt.-Woods and copses.

Nesting Period.-April to June. 
Site of Nest.-Dead tree stumps, holes in walls, etc.

Materials Used.-Similar to Blue Tit.

Eggs.-Six to Nine. Very similar to those of the Blue Tit.

Food.-Same as last named.

Voice.-Call, a shrill " che-chee, che-chee," and two clear-sounding notes like " if-hee, if-hee, if-hee."

Chief Features. - The sober plumage, black head (hence Coal Tit), white cheeks, and nape. Not so often seen as the Blue Tit.

Plumage.-Black on crown, throat, and front of neck; pure-white cheeks and nape; grey above; bluish-grey wings, with two white bands; white underneath, with a grey tinge. Length.Four and a quarter inches.

\section{TIT, CRESTED (Parus cristatus)}

Local Names.-None seem to be recorded.

Haunt.-Pine forests of Scotland.

Nesting Period.-April onwards.

Site of Nest.- Same as Coal Tit, and also in a Squirrel's drey or the disused nest of a Crow.

Materials Used.-Moss, grass, hair, fur, wool, and feathers.

Eggs.-Five or Six. White, spotted and speckled with brownish-red. Food.-Insects and their larvæ, and probably buds and small seeds. Voice.-Call, "seet, seet, seet," and a continuous "si, si, si," or "si, si, si, - ptur, re, re, re, ree."

Chief Features.- The rarest British Tit; a handsome little species, with a high, pointed crest, hence its English name.

Plumage.-Feathers of crown elongated, and forming when erected a pointed crest, black, edged with white; cheeks and neck sides white; throat, collar, and a streak across temples black; all other parts reddish-brown; lower parts white, faintly tinged with red. Length.-Four inches and three-quarters.

\section{TIT, GREAT (Parus major)}

Local Names.-Bee-Biter, Black Bluebonnet, Blackcap, BlackHeaded Tomtit, Charbonniere, Great Black-Headed Tomtit, Heckymal, Joe Bent, Oxeye, Pick-Cheese, Pridden Pal, Saw

Sharpener, Sit-ye-down, Tom Collier, Tomtit.

Haunt.-Woods, copses, groves, parks, and gardens.

Nesting Period.-April to June.

Site of Nest.-Similar to Blue Tit.

Materials Used.-See Blue Tit.

Eggs.-Six to Twelve. White, spotted with light brown.

Food.-Small insects, buds, sceds, and fruit. 
Voice.-A clever mimic, imitating the "pink, pink" of Chaffinch, call of Nuthatch, etc. In the Spring it utters a shrill tinkling song, such as " pinker, pinker," or "tree-sa-tree-sa."

Chief Features.-The largest British species, and the most handsome. To be distinguished by large size and the black head, throat, and band on the breast. Very pugnacious in habits, and will kill other birds in captivity.

Plumage.-Head, throat, and band down centre of breast black; olive-green back; white cheeks, and also a spot of same on nape; yellow breast and belly. Length.-Six inches.

\section{TIT, LONG-TAILED (Acredula rosea)}

Local Names.-Bag, Barrel Tit, Bellringer, Bottle Tit, Bottle Tom, Can-Bottle, Caper Longtail, Ekimol, Feather Poke, French Magpie, Jack-in-a-Bottle, Longpod, Long-Tailed Capon, LongTailed Mag, Long-Tailed Mufflin, Long-Tailed Pie, Long Tom, Mufflin, Mum-Ruffin, Nimble Tailor, Oven Builder, Poke Pudding, Ragamuffin, Rose Mufflin, Tree Huck-Muck.

Haunt.-Woods, commons, and hedge-

rows.

Nesting Period.-March to June.

Site of Nest.-Furze, blackthorn, and hawthorn bushes, etc.

Materials Used.-Moss, lichen, wool, spiders' webs, profusely lined with feathers. A globular nest, with small hole near top.

Eggs.-Six to Twelve, or more. White, with a few light-red spots.

Food.-Insects.

Voice. - A sibilous, subdued note, which, when uttered in chorus, is very pleasing.

Chief Features.-The long tail, engag-

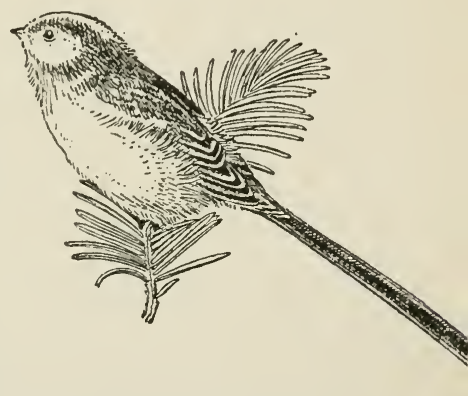

Fig. 40. Long-Tailed Tit. ing habits, and sociable disposition, the birds travelling about in little parties after nesting season is over. The nest is undoubtedly the finest example of avine architecture in the British Isles.

Plumage.-White on head, neck, throat, breast, and part of outer tail-feathers; black back, wings, and six middle tail-feathers; above the eye a streak of black; tinge of rose-red on sides of back and scapulars; reddish-white underneath. Tail very long; beak very short. Length.-Five inches and three-quarters. 


\section{TIT, MARSH (Parus palustris)}

Local Names.-Blackcap, Black-Headed Tomtit, Coalhead, Joe Bent.

Little Black-Headed Tomtit, Saw Sharpener, Smaller Oxeye,

Willow Biter.

Haunt.-Woods, commons, stream-sides, marshy ponds, etc.

Nesting Period.-April to June.

Site of Nest.- In a rotten tree stump, hole in a pollard willow, etc.

Materials Used.-Moss, wool, rabbit flick, willow catkins, etc.

Eggs.-Six to Eight. White, patched with light red-brown.

Food.-Same as Blue Tit.

Voice.-Various notes, such as "ti, ti," " chee-chee-chee;" a loud, continuous "tshay-tshay-tshay," etc.

Chief Features.-Although fond of marshy places, as the name implies, this species is by no means restricted to same. Somewhat like the Coal Tit, but the dull-white cheeks, throat, and breast at once distinguish it.

Plumage.-Black forehead, crown, nape, and head; grey above; dark-grey wings, edges lighter; dull-white cheeks, throat, and breast. Length.-Four inches and a half.

\section{TIVITE (Linota flavirostris)}

Local Names.-French Linnet, Heather Lintie, Mountain Linnet, Rockie, Rock Linnet, Rock Lintie, Twite Finch.

Haunt.-Moors, commons, and heaths.

Nesting Period.-End of May or early June.

Site of Nest.-Among herbage on, or close to, the ground, also in low bushes.

Materials Used.-Bents, twigs of heather, lined with fibrous roots, hair, wool, or feathers, the down of plants, etc.

Eggs.-Four to Six. White, tinged with faint blue or green, and

spotted with red or a darker tint.

Food.-Insects in Summer, small seeds in Winter.

Voice.-Call, "twite," or a long-drawn "twa-ite." The song is shriller than that of the Linnet, but not so good in quality.

Chief Features.-A typical moorland species; loves solitude. Much resembles its near relative the Linnet in habits. Resides in the North and Midlands.

Plumage.-Dark brown above, with light-brown edgings to feathers; tinge of red on rump of male; tawny-brown throat; dull-white breast and belly, with dark-brown streaks on flanks; yellow beak; dark-brown feet. Length.-Five and a quarter inches. 


\section{WAGTAIL, GREY (Motacilla melanope)}

Local Names.-Cow Bird, Dun Wagtail, Grey Wagster, Wangtail, Water Wagtail, Winter Wagtail, Yellow Wagtail.

Haunt. - Streams and

their vicinity.

Nesting Period.-April to

Site of Nest.-Under an overhanging bank, shelves of rocks, etc.

Materials Used.-Moss, bents, and roots, lined with hair. Eggs._Five or Six. Pale grey, clouded with faint creamybrown.

Food.-Insects.

Voice.-A shrill "tiz-it, tiz-it,"

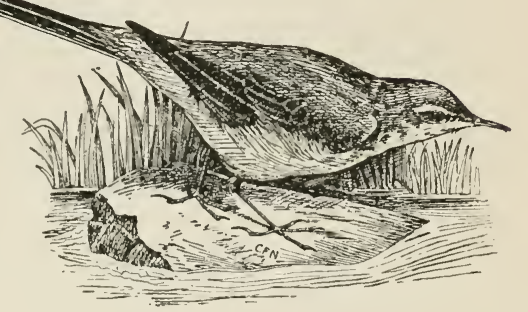

Fig. 4I. Grey Wagtail.

and a sweet, liquid song in early Spring and Autumn.

Chief Features.-Represents the first of an elegant family. Not by any means common, but resorts to same haunt year after year.

May be confused with Yellow Wagtail, but not nearly so brilliantly coloured (see Plumage).

Plumage.-Summer, bluish-grey head and back; pale streak over eye; black throat; bright yellow underneath. Winter, whitishyellow chin and throat. Length.- Seven inches and a half.

\section{WAGTAIL, PIED (Motacilla lugubris)}

Local Names.-Black and White Wagtail, Dish Washer, Nanny Wagtail, Nanny Washtail, Peggy Wash Dish, Peggy Wash Disher, Penny Wagtail, Quaketail, Wangtail, Wash Dish, Washer Disher, Washerwoman, Water Wagtail, White Wagtail, Willie Wagtail, Winter Wagtail.

Haunt.-Meadows, streamsides, gardens, etc.

Nesting Period.-April onwards.

Site of Nest.-In banks, piles of wood, holes and crevices in walls, and quarries, also eaves of haystacks, etc. 
Matcrials Used.-Grass, moss, and roots, lined with feathers, hair, and wool.

Eggs.-Four or Five. Greyish-white, spotted with greyish-brown. Food.-Insects.

Voice.-Call, "which-is-it," and a shrill "chiz-zit" on wing. Also utters occasionally a pleasant, subdued song.

Chief Features.-The striking appearance, elegant movements, and great activity of this, the smallest bird that walks, are well known. Fond of visiting sheepfolds in Winter for small insects. Plumage.-In Summer variegated with black and white; black on chin, throat, and neck; a little white on side of neck. In Winter the back and scapulars ash-grey; white chin and throat, with black gorget. Length.-Seven and a half inches.

\section{WAGTAIL, YELLOW (Motacilla rayii)}

Local Names.-Corn Willie, Cow Bird, Ray's Wagtail, Seed Bird, Seed Lady, Spring Wagtail, Summer Wagtail, Wangtail, Yellow Wagster.

Haunt.-Meadows, fields, stream-sides, etc.

Nesting Period.-May to July.

Site of Nest.-Banks and walls, or on the ground in fields of grass, corn, or turnips.

Materials Used.-Grass, roots, moss, feathers, and hair.

Eggs.-Five or Six. Whitish, mottled with yellow and ash-brown.

Food.-Insects.

Voice.-A shrill double alarm-note, and a few liquid notes uttered upon the wing.

Chief Features.-A Summer visitor only, arriving as early as March. The males, at such time, look very beautiful in their handsome dress. Fond of visiting cattle fields, where it runs about in a most engaging way. Winters in Africa.

Plumage.-Greenish-olive on top of head, lore, nape, back, and scapulars; over the eye a bright-yellow streak; sulphur-yellow underneath. Length.-Six inches.

\section{WARBLER, DARTFORD (Melizophilus undatus)}

Local Names.-Fire-Eyed Chat, Furze Wren.

Haunt.-Heaths, commons, etc.

Nesting Period.-April to June.

Site of Nest.-Near the ground in a thick furze bush.

Materials Used.-Dead grass, furze branches, and wool.

Eggs.-Four to Six. Greenish, closely freckled with olive-brown and cinercous, the markings ending in a zone at the larger end. 


\section{DARTFORD AND GARDEN WARBLERS}

Food.-Insects, including small moths.

Voice.-Call, "pit-et-chow-cha-ch-cha," or a clear and musical

"pitchoo." A curious, impetuous song.

Chief Features.-First noticed as a British bird by Dr. Latham in I773, he having procured a pair from Bexley Heath, near Dartford, Kent. It is a rare bird, but easily distinguished by the small size, long tail, short wings, and lively disposition.

Plumage.-Greyish-black; blackish-brown on wing-coverts and feathers; broadly tipped on outer tail-feathers, and narrowly elsewhere, with brownish-grey; chestnut-brown underneath; white belly; long tail; very short wings. Length.-Five inches.

\section{WARBLER, GARDEN (Sylvia hortensis)}

Local Names.-Fauvette, Fig Bird, Garden Fauvette, Greater Pettychaps, Nettlecreeper, Nettlemonger, Passerine Warbler.

Haunt.-Woods, copses, commons, and large gardens.

Nesting Period.-May and June.

Site of Nest.-A bramble or wild rose bush is a favourite site.

Materials Used.-Dried stems of goosegrass, roots, wool, and horsehair. A fragile structure.

Eggs.-Four or Five. Yellowish, mottled with brown and ash.

Food.-Small insects, and, it is said, fruit and berries.

Voice.-Call, a harsh "teck" or " chec;" when alarmed, "chutch" rapidly repeated. A brilliant song is uttered; it consists of a continuous ripple of

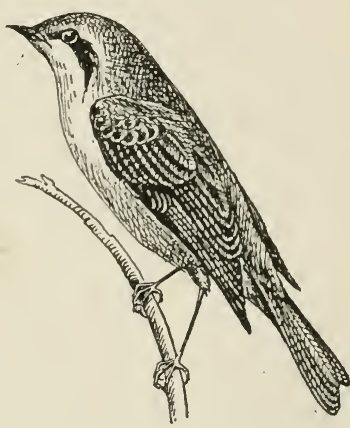

Fig. 43. Garden Warbler. delightful notes of little variation, but remarkably sweet. There is an absence of the thin, Whitethroat-like notes of the Blackcap's song, and the bird sings whilst incessantly searching for food.

Chief Features.-Although a very common Warbler, is doubtless overlooked, being restless and little known. A Summer Migrant, arriving from Africa about mid-April. Loves to hide among the broad leaves of the sycamore.

Plumage--Greyish-brown above, tinged with olive; a patch of ash-grey underneath the ear; dull white on throat; grey on breast and flanks, tinged with rust-colour; remaining under parts dull white. Length.-Five and a quarter inches. 


\section{WARBLER, GRASSHOPPER (Locustella navia)}

Local Names.-Birrl Bird, Brake-Hopper, Brake Locustelle, Cricket Bird, Grasshopper Lark, Locustelle, Rattlesnake Bird, RazorGrinder, Reeler.

Haunt.-Hedgerows and commons where grasses and other plants grow luxuriantly.

Nesting Period.-Mid-Nay to June, July, or August.

Site of Nest.-The base of a bush, on or close to the ground, and among thick clumps of grass.

Materials Used.-Moss, grass, and straw, lined with fine bents. Eggs.-Five to Seven. White, closely freckled with pinkish-red. Food.-Insects.

Voice.-The local names all indicate the chief trait in the character of this bird, namely, the remarkable song. It may best be compared to the rapid winding of a fisherman's reel, or the loud purring of a cat. The vibrating notes are uttered as the male turns his head rapidly from side to side, and this enhances the curious effect. The song is uttered at dusk, and also in the early morning.

Chief Features.-The song above referred to. This is a very local Summer Warbler, comparatively shy. Arrives about mid-April. Plumage.-Light greenish-brown above, a mottled appearance being given by the middle of each feather being darker; pale brown underneath, with darker brown spots on neck and breast; light-brown feet. Female lacks the brown spots on breast. Length.-Five and a half inches.

\section{WARBLER, MARSH (Acrocephalus palustris)}

Local Names.-None appear to be recorded.

Haunt.-Near ponds, lakes, rivers, and marshy places.

Nesting Period.-June and July.

Site of Nest.-Low down among osiers, near but never over water. Materials Used.-Moss, leaves, and grass, felted together with willow down and spiders' webs; lined with horsehair.

Eggs.-Six or Seven. Greyish-white, marbled with purplish-brown. Food.-Insects.

Voice.-A sweet but not loud song, richer than that of the Reed Warbler. Call, a harsh "turr."

Chief Features.-First discovered in England in I86I, and is now commoner than was supposed. May be confused with the Reed Warbler, but points set out below should be carefully noted. A late Summer Migrant, arriving about mid-May.

Plumage.-White throat, which is fluffed out as the bird sings; 
brown head, without any visible stripe over the eye-though there seems to be reason to believe that this becomes slightly apparent in mature individuals; olive-brown back, and fleshcoloured legs.... The Reed Warbler differs in having a more rufous back and slate-coloured legs.

\section{WARBLER, REED (Acrocephalus streperus)}

Local Names.-Marsh Reedling, Night Warbler, Reed Bird, Reed Chucker, Reed Wren, Water Sparrow.

Haunt.- Similar to Marsh Warbler, but sometimes away from water. Nesting Period.- - June and July.

Site of Nest. - Between the stems of reeds.

Materials Used.-Reeds, moss, wool, leaves, and dry grass. The deep nest is attached to reed stems in an ingenious way.

Eggs.-Four or Five. Greenish-white, spotted and dashed with green and pale brown.

Food.-Small insects.

Voice.-Reminds one of the song of the Sedge Warbler, but is less powerful, although sweeter. Call, "turr" or "choh, choh."

Chief. Features.-A much commoner Warbler than is supposed.

Somewhat of a colonist, thirty nests having been found by a friend of mine on an eyot on the Thames during one afternoon. A Summer Migrant, arriving towards the end of April or early in May. Of shy, skulking habits, and largely nocturnal.

Plumage.-Reddish-brown above, without spots; between eye and beak a spot or streak of white; white throat; pale buff underneath. Length.-Five and a half inches.

WARBLER, SEDGE (Acrocephalus phragmitis)

Local Names.-Blethering Tam, Chittering Tam, Lesser Reed Sparrow, Lesser Water Sparrow, Mock Bird, Night Singer, Phragmite, Reed Fauvette, Sally Picker, Sedge Bird, Sedge Marine, Sedge Reedling, Sedge Wren, Shamcider.

Haunt.-Rivers, ponds, lakes, ditches, and where there are reed patches or other herbage.

Nesting Period.-May and June.

Site of Nest.-A low, thick bush, or in a tuft of grass. Materials Used.-Moss, coarse grass, and stems of plants, lined with finer grass and hair.

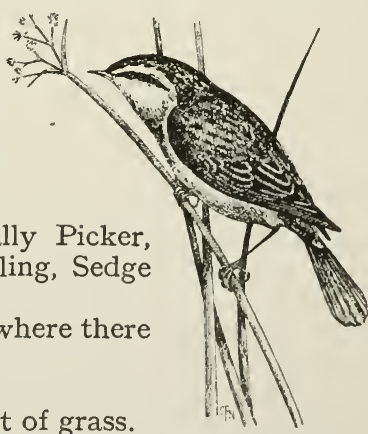

Fig. 44. Sedge Warbler. Eggs.-Five to Seven. Pale yellowish-brown, mottled with darker brown. 
Food.-Water insects and their larvæ, and slugs.

Voice.-Call, " cheep," or a harsh "turr;" also a soft "wheetwheet." Alarm, "tut-tut;" song, "chuck, chuck, chuck, chuck, chuck, click, click." An impetuous utterance.

Chief Features.-A Summer Migrant, arriving towards end of April. A shy bird, and hates being watched. Has the habit of uttering a vehement song when a stone or other missile is thrown near its haunt. Mimics the calls and cries of other birds. Streak over eye a good method of identification.

Plumage.-Greyish-brown above; a broad, distinct, yellowish-white streak above eye; pale buff underneath; white throat. Length.-Four inches and three-quarters.

\section{WARBLER, WILLOW (Phylloscopus trochilus)}

Local Names.-Bank Jug, Bee, Billy, Grosbeak, Ground Huck-Muck, Hay Bird, Hazock Wren, Muftie Wren, Oven Bird, Oven Tit, Peggy, Peggy Whitethroat, Sally Picker, Scotch Wren, Silver Wren, Smew, Strawsmeer, Tom Thumb, White Wren, Willie Muftie, Willow Sparrow, Willow Wren, Wren Lintie, Yellow Warbler, Yellow Wren. Haunt. - Woods, copses, plantations, commons, and gardens. Nesting Period.-May and June. Site of Nest.-On the ground among grass, or at the base of a bush.

Materials Used. - Moss, leaves, grass, and horsehair, with a

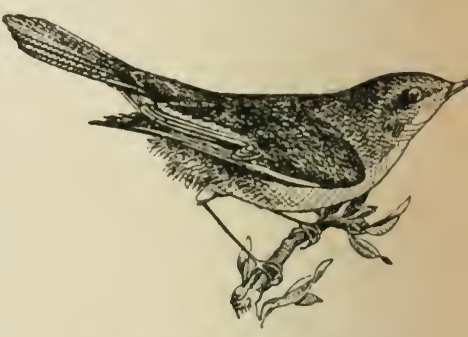

Fig. 45. Willow Warbler.

profuse feather lining. Dome-shape, and similar to that of Chiff Chaff.

Eggs.-Six to Eight. White, freckled with light red.

Food.-Insects.

Voice.-A simple refrain, little varied but very sweet. Call, "foreet " and " hoid-hoid;" otherwise "tu-it" or "weep-ep."

Chief Features.-Haunts tall trees and bushes, and resumes Spring song in August. A Summer Migrant, arriving early in April. Care should be taken not to confuse this bird with the Chiff Chaff. Compare plumage and notes.

Plumage.-Bright olive-green above; above eye a narrow yellow streak; yellowish-white underneath, palest towards centre; yellow leg-feathers. Length.-Almost five inches. 


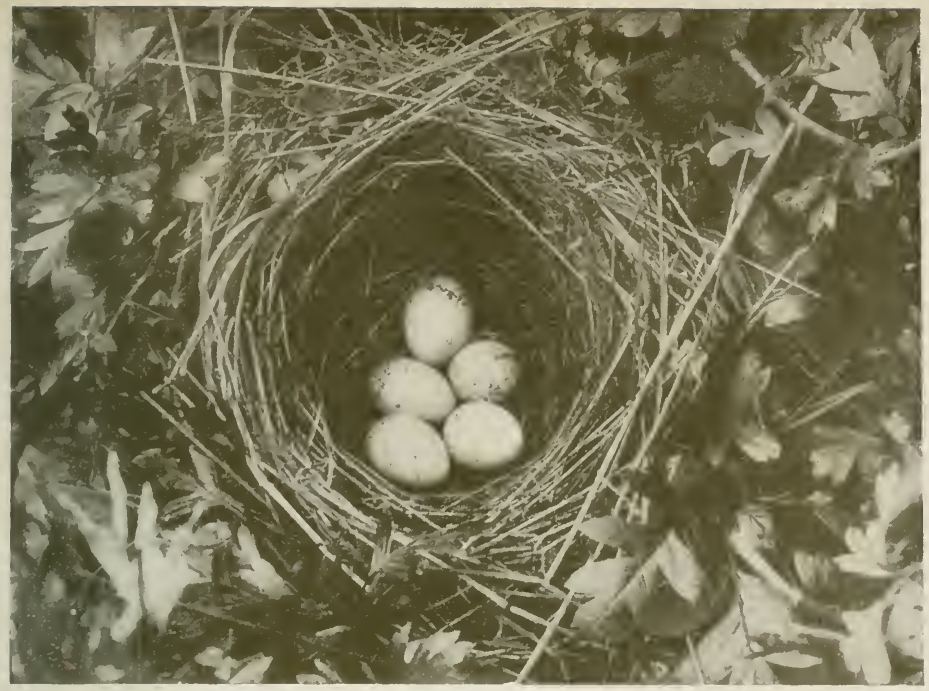

Nest AND EgGS OF Greater Whitethroat.

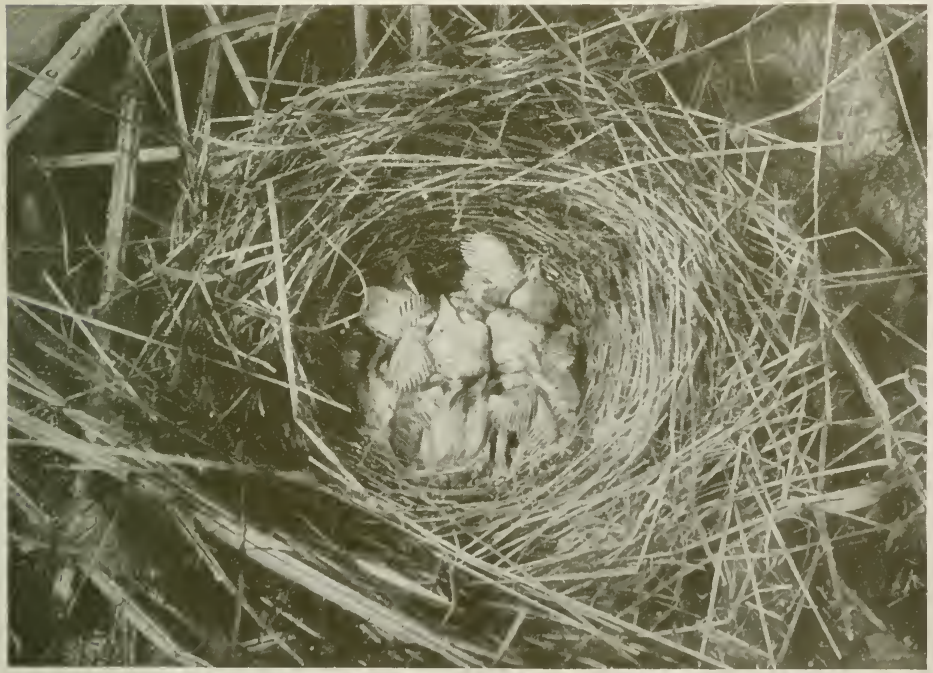

Young (ireater Whitethroats. 


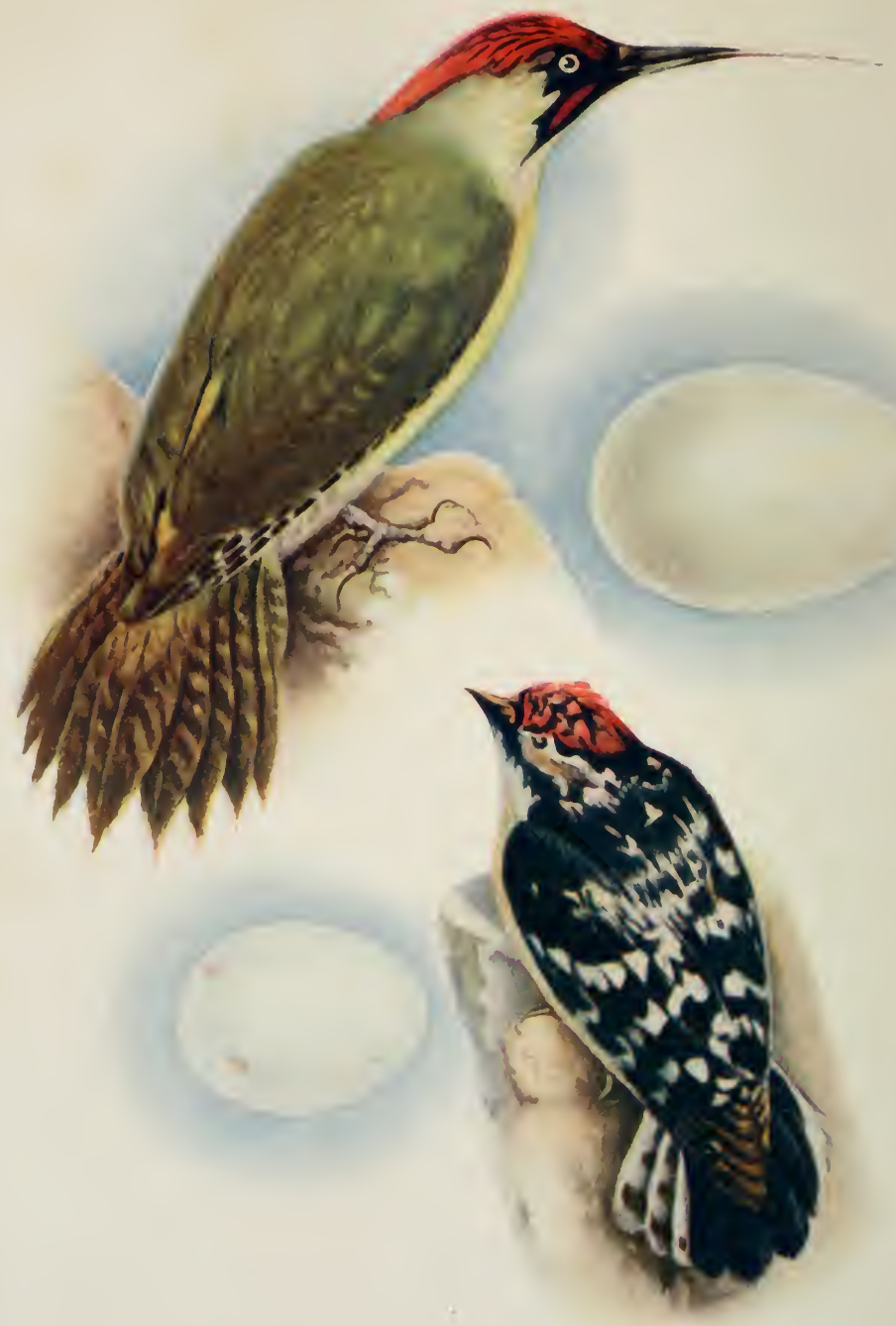

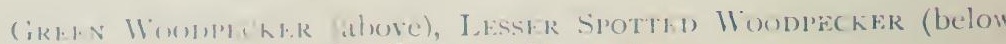

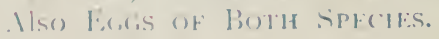




\section{WARBLER, WOOD (Phylloscopus sibilatrix)}

Local Names.-Green Wren, Hay Bird, Larger Willow Wren, Larger Yellow Wren, Largest Willow Wren, Linty White, Willie Muftie, Wood Wren, Yellow Bird, Yellow Warbler, Yellow Willow Wren, Yellow Wren.

Haunt.-Woods, especially beech.

Nesting Period.-May and June.

Site of Nest.-On the ground among grass, heath, etc.

Materials Used.-Moss, hay, leaves, lined with horsehair and fine

grass. Dome-shape. Note.-No feathers are used.

Eggs.-Five to Seven. White, spotted and speckled with dark red. Food.-Small insects.

Voice.-A curious little song, uttered persistently, but lacking sweetness, the latter part of it running into a trill. It is accompanied by a shivering of the wings. Call of male, "twee, twee, twee;" female alarm-note, "wee-eep."

Chief Features.-Locally distributed, and not nearly so common as Chiff Chaff and Willow Warbler. A Summer Migrant, arriving from Africa end of April or early May.

Plumage.-Above olive-green, with tinge of sulphur-yellow; above the eye a broad streak of the latter; bright yellow on sides of head and throat, and insertion of wings and throat; remainder of under plumage pure white. Length.-Nearly six inches.

\section{WHEATEAR (Saxicola cenanthe)}

Local Names.-Chack, Chack Bird, Chacker, Chat, Chickell, Chicker, Chuck, Clocharet, Clodhopper, Cooper, English Ortolan, Fallow Chat, Fallow Finch, Fallow Lunch, Fallow Smick, Fallow Snatch, Horse Smatch, Jobbler, Shepherd Bird, Singing Skyrocket, Snorter, Stenikle, Stone Chacker, Whiterump, Whitetail. Haunt.-Downs, moors, mountains, and other desolate places.

Nesting Period.-April onwards.

Site of Nest.-On the ground, as well as crevices in walls, under stones, clods, etc.

Materials Used.-Dry grass, moss, bents, wool, and hair.

Eggs.-Four to Six, or more. Pale greenish-blue.

Food.-Insects.

Voice.-Call, an oft-repeated "chick-chack-chack;" also a soft, sweet song.

Chief Features.-The handsome appearance of the male bird on his arrival in the early Spring. A restless species; displays a prominent white rump when flying.

Plumage.-Bluish-grey above; black on wings and wing-coverts, 
centre and end of tail, bill, feet, eyes, and ears; white at base and lower portion of side of tail, also on chin, forehead, stripe over eye, and under parts. During Autumn reddish-brown above, and the tail-feathers have white tips. Female ashbrown above, tinged with yellow, and eye stripe dingy colour. Length.-Six and a half inches.

\section{WHIMBREL (Numenius pheopus)}

Local Names.-Chequer Bird, Chickerel, Curlew Knot, Half-Calloo, Half-Curlew, Jack Curlew, Knot Curlew, Little Whaap, Long Whaap, Maybird, Seven Whistler, Stone Curlew, Tang Whaap, Titterel, Whimbrel Curlew.

Haunt.-Moors and mountains in Spring and Summer; seashore, saltings, and mudflats in Winter.

Nesting Period.-End of May and throughout June.

Site of Nest. - A slight hollow in the ground.

Materials Used.-Heather twigs and a few pieces of dry grass.

Eggs.-Four. Olive-brown, marked with darker brown.

Food.-Marine insects, crabs, and worms.

Voice.-Call, a shrill "curlee," a whistling and oft-repeated " titterel," and "tetty, tetty, tet."

Chief Features. - Nests in the far North, but many come South in

Winter. Not so shy and wary as the Curlew. May be known by the smaller size.

Plumage.-Dark-brown crown, with a broad pale streak down centre;

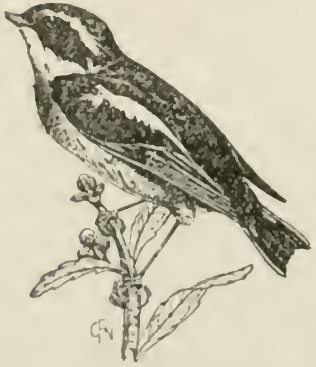

Fig. 46. Whinchat. above similar to Curlew, but darker; white axillaries, barred with brown. Length.Female, eighteen inches.

\section{WHINCHAT (Pratincola rubetra)}

Local Names.-Bank Sparrow, Furze Chat, Furze Chuck, Gorse Chat, Gorse Linnet, Grass Chat, Horse Smatch, Ring Fowl, Stone-chack, Utick, Whin Bushchat.

Haunt.-Commons, heaths, railway banks, and waste places.

Nesting Period.-May and June.

Site of Nest.-On or close to the ground.

Materials Used.-Coarse and fine grass, moss, and straws; sometimes roots and hair.

Eggs.-Four to Six. Greenish-blue.

Food.-Insects (including small beetles) and their larvæ, worms, etc. 
Voice.-A low warbling song, uttered with great persistency. Call, "utac-tac-tac-tac;" also " chee-tic, chee-tic-tic-tic."

Chief Features.-A Summer Migrant, arriving from Northern Africa about the middle to end of April. A solitary species; returns to the same haunt year after year. Notice the prominent white stripe over the eye.

Plumage.-Above dusky-brown, with reddish-yellow edgings; over eye broad white stripe; white on throat and neck sides; bright yellowish-red on neck and breast; on wings and at base of tail a large white spot; dusky-brown on tip of tail and two centre feathers; yellowish-white belly and flanks. Female duller and white wing spot smaller. Length.-Five inches and a quarter.

\section{WHITETHROAT, GREATER (Sylvia cinerea)}

Local Names.-Beardie, Bee Bird, Billy, Blethering Tam, Charlie Miftie, Churn, Common Whitethroat, Hay Chat, Hay Tit, JackStraw, Megg Cut-Throat, Muff, Muffit, Muftie, Muggy, Nettlecreeper, Nettlemonger, Peggy Whitethroat, Singing Skyrocket, Strawsmeer, Whantie, Wheetie, Wheetie-Why Bird, Whiskey, Whitecap, White Lintie, White-Throated Warbler, White Wren. Haunt.-Hedgerows, copses, gardens, etc. Nesting Period.-May to July.

Site of Nest.-Bushes, nettles, bank-sides, etc.; usually low down.

Materials Used.-Fine grass, lined with hair.

Eggs.-Five or Six. Greenish-yellow, marked with darker shades.

Food.-Small larvæ and a little fruit.

Voice.-A harsh, impetuous song; notes thin and screechy. Call, "tyœ," "teh," or "trr" (harsh); alarm, "wick-a-wick."

Chief Features. - A common Summer Migrant, arriving about mid-April.

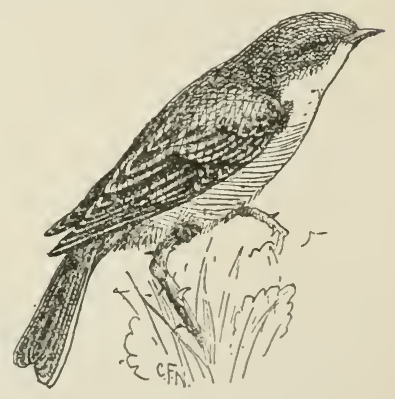

Fig. 47. Greater Whitethroat.

An active little bird, and may be observed fluttering over a hedgerow or bush and singing impetuously. Utters a scolding note of defiance; raises feathers of head excitedly; slips off nest very quietly.

Plumage.-Ash-grey head, with brown tinge; remainder of upper plumage reddish-brown; dusky wings, with red edging on coverts; white underneath, tinged faintly with rose; darkbrown tail, white on tips of outer feathers and outer web, the next tipped only with white. Female lacks rosy tint on breast. Length.-Five and a half inches. 


\section{WHITETHROAT, LESSER (Sylvia curruca)}

Local Names.-Babillard, Brake Nightingale, Hay-Jack, Jack-Straw, White-Breasted Warbler.

Haunt.-Woods, copses, hedgerows, and gardens.

Nesting Period.-May to July.

Site of Nest.-Hedges, bushes, etc. Nest is placed higher than that of Greater Whitethroat, and is deeper.

Materials Used.-Fine grass, spiders' webs, stalks of plants, hair, and roots.

Eggs.-Four or Five. White, marked with ash and light brown.

Food.-Small larvæ and green fly, also fruit.

Voice.-A succession of hurried notes, mostly in one strain. Call, " check," and a harsh "teck."

Chief Features.-To be distinguished by smaller size than the Greater species, and is much shyer. A common species, and often overlooked. Appears to be increasing its range Arrives from Winter quarters about middle of April. A Summer Migrant. Plumage.-Smoky-grey head, neck, and back; almost black on earcoverts; brown on wings, with grey edges; dusky tail, outer feathers as in Greater species, the two following with white tips; almost pure white on lower parts; lead-colour feet. Length.-Five and a quarter inches.

\section{WIGEON (Mareca penelope)}

Local Names.-Bald Pate, Common Wigeon, Easterling, Pandled Whew, Pundle, Whew Duck, Whewer, Whim.

Haunt.-Lakes, swampy places, saltings, etc.

Nesting Period.-May.

Site of Nest.-Among rushes, etc.

Materials Used.-Dead water plants, lined with sooty-brown down. Eggs.-Five to Nine. Creamy-white; 2.50 by 1.50 inches.

Food.-Tender parts of plants, insects, etc.

Voice.-Call, "whew-whew-whew." Male, a shrill and clear " pipe" when alone, soft and little repeated in company; female, a loud and long " purre" when alone, also a shrill " whistle."

Chief Features. - A fine bird upon the wing, especially when a company come swinging in from sea. A very handsome Duck; docile; a goorl swimmer. Female covers eggs before leaving nest. Plumage.-Dull-blue bill; cream-white forehead and crown; chestnut chin, neck, and throat; cheeks and hind neck spotted minutely with dark green; white breast; grey underneath, dark-grey pencil markings on flanks; vermiculated grey mantle; 
white shoulder, with terminal black bar, followed by green speculum, tipped with black underneath; dark-brown wing and tail-feathers; same colour on legs and feet. Female mottled with greyish-brown above; whitish on shoulder; greyish-green speculum; underneath mottled buffish-white. In July male assumes plumage of female. Length.--Eighteen inches.

Local Name.-Cock.

\section{WOODCOCK (Scolopax rusticula)}

Haunt.-Woods, plantations, damp moors, and spinneys.

Nesting Period.-March to May.

Site of Nest.-A slight depression in the ground, at foot of a tree, etc. Materials Used.-Dead grass, leaves, and bracken.

Eggs. - Four. Dirty white,

blotched and spotted with various shades of pale brown and purplish-grey.

Food.-Insects and worms.

Voice.-Call, a shrill Snipe-like "skaych" and "vessop." On wing, " crok, crok, weet, crok, crok, weet " ("crok" hoarse, "weet " sharp). Barks and hisses when young are molested.

Chief Features.-A wandering bird, nocturnal in habits; carries its young away when in danger. Possesses a remarkable darting flight. Male resorts to curious antics at pairing time. A

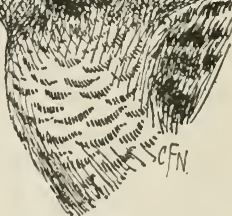

Fig. 48. Head of Woodcock.

large immigration takes place on our shores during Autumn.

Note long beak and bulbous eye near forehead.

Plumage.-Reddish-brown above, barred and vermiculated with black; wood-brown underneath, with darker bars of brown. The sexes are similar. Length.-Fourteen inches.

\section{WOODLARK (Alauda arborea)}

Local Names.-Lark, Laverock, Woodwell.

Haunt.-Woods and commons.

Nesting Period.-March onwards.

Site of Nest.- On the ground among herbage, or in a low bush. Materials Used.-Grass and bents, sometimes a little moss outside and hair inside.

Eggs.-Four or Five. Greyish, closely freckled with reddish-brown. Darker and smaller than those of the Skylark.

Food.-Insects, grass blades, and seeds. 
Voice.-The song is very similar to that of the Skylark, but is sweeter and not so powerful.

Chief Features.-Not nearly so common as the Skylark. May be known by smaller size, short tail, and streak over eye. Ascends in circles, and also sings when perched in a tree. Will ascend from latter like the Tree Pipit.

Plumage.-Reddish-brown above, middle of each feather dark brown; over eye a prominent streak of yellowish-white, which extends to back part of head; yellowish-white underneath, streaked with dark brown; tail very short. Length.-Six and a half inches.

\section{WOODPECKER, GREAT SPOTTED (Dendrocopus major)}

Local Names.-French Pie, French Woodpecker, Great Black and White Woodpecker, Middle-Spotted Woodpecker, Pied Woodpecker, Spickle-Pied Woodpecker, Whitall, White Woodpecker,

Whit-Wall, Witall or Witwall, Woodall, Woodnacker, Wood Pie. Haunt.-Woods, parlis, and orchards.

Nesting Period.-End of May and June.

Site of Nest.-A hole in a tree.

Materials Used.-None, except chips of wood which are left after hole has been excavated.

Eggs.-Four or Five. Glossy white; r.05 by .75 inch.

Food.-Insects, etc.

Voice.-Call, "chik, chick, chink;" "slack, slack;" "chack, clack;" a shrill "whit," and a higher-toned note something like that of Green species.

Chief Features. - The least distributed of the three British Woodpeckers. May be known by large size, black and white dress, and crimson on head, belly, and under tail-coverts.

Plumage.-Black crown and upper parts; on back of head a patch of crimson; white scapulars, lesser wing-coverts, and underneath; crimson on belly and under tail-coverts. Female lacks crimson on head. Length.-Nine and a half inches.

\section{WOODPECKER, GREEN (Gecinus viridis)}

Local Nanzes.-Awl, Awl Bird, Eaqual, Ecle, French Pie, Gally, Hew-Hole, High Hoe, Large Green Woodpecker, Mele, Nick-aPecker, Pick-a-tree, Poppinjay, Rain Bird, Rain Fowl, Tongue Bird, Wet-wet-more-wet, Whet-Ile, Whittle, Witwall, Woodspite, Woodwall, Yaffer, Yaffingale, Yaffle, Yaffler, Yappingale, Yawkle.

Haunt.-Woods and parks. 


\section{GREEN AND SPOTTED WOODPECKERS}

Nesting Period.-End of April or early May.

Site of Nest.--Same as last species.

Materials Used.-Same as last species.

Eggs.-Four to Seven. Glossy white; r.3 by .92 inch.

Food.-Acorns, fruit, nuts, seed, insects, their larvæ and pupæ.

Voice-Characteristic notes, a laughter-like "ha-haha-ha."

Chief Features.-One of the most handsome British birds. Fond of visiting ant-hills, but, with this exception, rarely seen on ground. Laughter - like notes a feature of woodland sounds. When uttered, notes are said to foretell rain.

Plumage. - Olivegreen above; yellow rump; greenish - grey underneath;

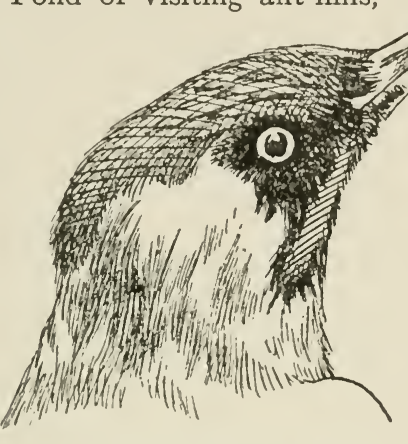

Fig. 49. Head and Tongue of Green Woodpecker.

crimson crown, back of head, and moustaches; black face. Female has less crimson on head, and has black moustaches. Length.-Thirteen inches.

\section{WOODPECKER, LESSER SPOTTED (Dendrocopus minor)} Local Names.-Barred Woodpecker, Crank Bird, French Magpie, Hickwall, Least Spotted Woodpecker, Little Black and White Woodpecker, Little French Woodpecker, Pump-Borer, Wall Hick.

Haunt.-Woods, groves, and parks.

Nesting Period.-End of May or early June.

Site of Nest.-Same as other species.

Materials Used.-Small chips of wood.

Eggs.-Four or Five. White; .76 by $.5^{8}$ inch.

Food.-Usual Woodpecker diet.

Voice.-A loud "chee-chee-chee-chee-chee," like that of Wryneck, but less shrill. Call, "kink-kink." Chief Features. - A common inhabitant of woods. Very vociferous 
in Spring. Makes, like its relatives, a peculiar drumming noise, produced by rapid vibration of beak when searching for insects.

Plumage.-Dirty white on forehead and lower parts; bright-red crown; black nape, back, and wings, barred with white; black tail, with white tips and black bars on outer feathers; red iris. Length.-Five and a half inches.

\section{WREN, BROWN (Troglodytes parvulus)}

Local Names.-Birritie, Bobbie Wren, Chitty Wren, Crackadee, Crackit, Cutty Wren, Jenny Wren, Jilliver Wren, Jimpo, Katy Wren, Kitty Wren, Our Lady's Hen, Ran, Sally Wren, Scutty, Stag, Tidley Creeper, Tidley Wren, Titty Dodger, Titty Wren, Tomtit, Tope, Vraun, Wrannock, Wranny.

Haunt.-Woods, copses, hedgerows, and gardens.

Nesting Period.-March onwards.

Site of Nest.-Hedges, bracken, holes in posts, and quarries; also in haystacks, banks, outbuildings, etc.

Materials Used.-A domed nest, with small hole near the roof; dead leaves, mosses, lichens, and twigs, lined with hair and feathers. Eggs.-Six to Twelve. White, with faint red spots.

Food.-Insects, spiders, wood-lice, and scraps in Winter.

Voice.-Call, "tit," "tit-it," and a loud, high-pitched song, wonderfully powerful for such a small bird.

Chief Features.-Plump body, short tail, remarkable song, butterflylike flight, mouse-like creeping habits, and shy nature. Nest often harmonises with surroundings. Sings in depth of Winter, and has no definite song period.

Plumage.-Above reddish-brown, with transverse dusky bars; quills alternately barred with black and reddish-brown; dusky tail, with black bars; pale narrow streak over eye; reddish-brown underneath; dark streaks on flanks and thighs. Length.Three inches and a half.

\section{WREN, GOLDEN-CRESTED (Regulus cristatus)}

Local Names.-Bee Bird, Crowned Kinglet, Crowned Wren, GoldenCrested Kinglet, Golden-Crested Regulus, Golden-Crested Warbler, Herring-Spink, Kinglet, Marygold Finch, Miller's Thumb, Moonie, Tidley Finch, Tot-o'er-Seas, Whiskey, White

Wren, Woodcock Pilot, Wood Titmouse. Haunt.-Woods, plantations, and large gardens.

Nesting Period.-April to June.

Site of Nest.-Under a branch of a fir tree. 


\section{GOLDCREST AND WRYNECK}

Materials Used.-Moss, leaves, fine grass, lichen, and spiders' webs, lined with feathers.

Eggs.-Six to Ten. Dirty white, marked with very light brown.

Food.-Insects.

Voice.-A low, continuous, sibilous note, running into a trill.

Chief Features.-The smallest British bird. Haunts tops of fir trees, and very difficult to watch. The yellow and orange crest and small size at once identify it.

Plumage.-Above olive, with a yellow tinge; ash-coloured cheeks; greyish-brown wing, with two transverse white bands; brightyellow crest in front, orange behind, bounded by two black lines; yellowish-grey underneath. Female not so bright, and crest lemon-colour. Length.-Three and a half inches.

\section{WRYNECK (I $\ddot{n} n x$ torquilla)}

Local Names. - Barley Bird, Cuckoo's Foal, Cuckoo's Leader, Cuckoo's Maid, Cuckoo's Mate, Cuckoo's Messenger, Dinnick, Emmet Hunter, Leader, Long Tongue, Pay-Pay, Pea Bird, Rinding Bird, Snake Bird, Tongue Bird, Turkey Bird, Willow Bite.

Haunt.-Woods, commons, parks, and large gardens.

Nesting Period.-May and June.

Site of Nest.-Holes of trees, not often made by the bird itself.

Materials Used.-Chips of decayed wood. Eggs.-Six to Eight. Glossy white; oval. Food.-Insects and larvæ; also said to be fond of elderberries.

Voice.-A shrill " pee-pee-pee-pee-pee." Call, "quee, quee," "quay, quay;" love-note, "gui, gui, gui."

Chief Features.-A Summer Migrant,

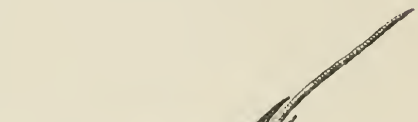

arriving end of March, usually before Cuckoo. Has a long tongue for licking up insects. Turns its head rapidly, and hence name Wryneck.

Plumage.-Above reddish-grey, with- irregular brown and black spots and lines; from back of head to back a broad black and brown band; dull white underneath, with buff tinge, and darkbrown bars with exception of breast and belly, where arrowheaded markings are found; on outer web of quills rectangular, alternate black and yellowish-red spots; tail-feathers barred with black and zigzag bands; olive-brown beak and feet. Length.-Seven inches. 


\section{N D E X}

Note.-Local and old-fashioned names are printed in ordinary type; correct English names in italics.

A BERDEVINE, 94

Ailsa Parrot, 84

Alk, 86

Allan, 95

Alovet te, 95

Alp, I 8

Annet, 55

Arbour Bird, 25

Arctic Bird, 95

Aron, 52

Arsfoot, 48, 49

Ash-Coloured Loon, 48

Ash-Coloured Swan, 48

Assilag, 77

Atteal Duck, 83

Auk, 86

Awl Bird, I 20

Babillard, I 8

Bald Buzzard, 57, 70

Bald Duck, 26

Bald Pate, i 8

Bank Bottle, 25

Bank Jug, I I 4

Bank Sparrow, I I 6

Bank Swallow, 65

Bar Drake, 66

Bare-faced Crow, 89

Bargander, 92

Bargoose, 92

Barley Bird, 9.4, I23

Barrel Tit, ro7

Bass Cock, 84

Bastard Plover, 63

Bay Duck, 92

Bay, Iо7

Beam Bird, 44

Bearded Reedling, 104

Beardie, II7

Beaucrake, 28
Bee Bird, 44, Io6, II 7, I 22

Beech Finch, 24

Bell Throstle, I03

Bellringer, 107

Belpoot, 26

Benny Ducker, 34

Big Now, IO2

Big Razor-Grinder, 68

Bilcock, 85

Billy, 96, I I 4, II 7

Billy Biter, I05

Billy Wix, 7I

Birritie, I 22

Birrl Bird, II 2

Black Back, 54

Black-Backed Falcon, 43

Black-Billed Auk, 86

Blackbird, I 7

Black - Breasted Plover, 8I

Blackcap, I 7

Black - Chinned Grebe, 49

Black Cock, 50

Black Crow, 30

Black Diver, 90

Black Duck, $9^{\circ}$

Black Felt, 98

Black-Headed Buschat, 98

Black-Headed Tomtit, , 06 , ro8

Black - Headed Wigeon, 83

Black Martin, Ioo

Black Ousel, I7

Black Oxeye, I05

Black Poker, 39

Blacksmith, 22
Black Swallow, roo Black Thrush, I 7

Black-Toed Gull, 95

Blacky-Topper, 17

Black Wren, 96

Blethering Tam, 98, II 3 , II 7

Blood Hawk, 23

Blood-Ulf, I 8

Blue-Backed Falcon, 43

Bluebonnet, I05

Bluecap, Io5

Blue Gled, 56

Blue Hawk, 43, 56,

$$
58,67
$$

Blue Isaac, 96

Blue Jacker, 57

Blue Jamie, 96

Blue Kite, 56

Blue Maa, 53

Blue Merlin, 58

Blue Mope, I05

Blue Oxeye, Io5

Blue Poker, 83

Blue Rock, 37

Blue Tom, 96

Blue Tomtit, ro5

Blue Whaup, ro5

Blue-Winged Shoveler, $9^{2}$

Blue-Winged Stint, 92

Boatswain, 95

Bobbie, 87

Bog Lark, 78

Boldie, 24

Bonger Cockandy, $\mathrm{S}_{4}$

Bonxic, 94

Bottle Tom, I07

Brake Locustelle,

II 2
Bran, 30

Brancher, 46

Bran-Tail, 89

Broad Bill, 92

Brook Ousel, 34

Brook Ouzel, 85

Brook-Runner, 85

Brown Gull, 94

Brown Hen, 50

Brown Phalarope, 77

Brown Woodpecker, 29

Buck Finch, 24

Budpricker, I8

Bullfinch, I 8

Bullock's Petrel, 76

Bully, I 8

Bundie, 40

Bunting Crow, 30, 3 I

Buntings, 19-22

Burrow Duck, 92

Bush Dove, 37

Bush Lark, I9

Butcher Bird, 93

Buzzard, 23

Caley Tit, I05

Calloo, 32

Can Bottle, ro7

Capercaillie, 23

Caper Longtail, 107

Cargoose, 48

Cat Gull, 55

Caw, 60

Chack, I I5

Chack Bird, I 15

Chaffinch, 24

Chaffy, 24

Chait, 44

Chalder, 74

Chaldrick, 74 
Chanchider, 44

Chank Daw, 25

Channel Goose, 45

Charbob, 24

Charbonniere, I o6

Chardonneret, 46

Charlie Miftie, I 7

Chat, II5

Chatterpie. 64

Cheeper, 78

Cheese, 22

Cheeter, 93

Chepster, 98

Chequer Bird, I 6

Cherry Chopper, 44

Cherry Finch, $5^{8}$

Cherry Sucker, 44

Cherubim, 7I

Chevvy Linnet, 87

Chickell, I I 5

Chicker, II 5

Chickerill, I I 6

Chickstone, 98

Chif Chaf, 25

Chin Chacker, 78

Chip Chop, 25

Chit Perl, Io2

Chittering Tam, I I 3

Chough, 25

Chuck, 58, I I 5

Churn, I 7

Churn Owl, 68

Churr, 40

Cinereous Godwit, 50

Cliff Daw, 25

Cliff Hawk, 43

Clocharet, I 5

Clod Bird, I9

Clodhopper, I 5

Coal Finch, 43

Coalhead, 20, 46, 105, 108

Cob, 54

Cobble, 35

Cobble Bird, 58

Cobweb Bird, 44

Cock, I I 9

Cock of the Mountain, 23

Cock-up, 78

Coddy Moddy, 53

Cog, 3 I

Cole Goose, 27

Cole Mouse, Io5

Colk, $3^{8}$

Common Gallinule, 67
Cooper, I 5

Coot, 26

Coot Foot, 77

Copper Finch, 24

Corbie, 86

Corbie Crake, 30, 3 I

Cormorant, 27

Corncrake, 28

Cornish Chough, 25

Cornish Gannet, 94

Cornish $\mathrm{Kae}, 25$

Corn Willie, I Io

Coulterneb, 84

Cow Bird, ro9, I ro

Crackadee, 122

Cracker, 28

Crackit, I 22

Crake, 28

Cran, 100

Crank Bird, I2 I

Creeper, 29

Creetier, Tree, 29

Creepie, 96

Crek, 28

Creshawk, 6r

Crested Cormorant, 9 I

Crested Lapwing, 63

Crested Scarf, 9I

Crested Shag, 9 I

Crick, 46

Cricket Bird, I I 2

Cricket Teal, 46

Crock, 53

Crossbill, 30

Crotched - Tailed Puttock, 62

Crow, 30, 3 I

Crowned Kinglet, 122

Cuckoo, 3 I

Cuckoo's Leader, I 23

Cuckoo's Maid, 93, I 23

Cuckoo's Mate, I23

Cuckoo's Messenger, 123

Cuddy, 29, 67, 96

Culver, 36

Curlew Knnt, I 6

Curlew, 32

Cushat Doo, 36

Cygnet, roo

Dabchick, 49

Dad Finch, 24
Daker Hen, 28

Dark-Footed Pettychaps, 25

Davelin, roo

Daw, 6o

Denchman, 3 I

Deviling, roo

Devil's Bird, 22

Devil's Screech, I oo

Devil Swallow, Ioo

Dick Dunnock, 96

Dicky, 96

Didapper, 49

Dipper, 34

Dirty-Állen, 95

Dish Washer, Iog

Dive Dapper, 49

Diver, 34, 35

Diver, 48

Diving Goose, 66

Dob-Chicken, 49

Dog Hawk, 68

Doney, 96

Door Hawk, 68

Dotterel, 35

Dotterel Plover, 35

Doup, 30

Dove, 36-38

Dove - Coloured

Falcon, 56

Dove Hawk, 56

Dovekie, 52

Draw Water, 46

Duck, 38, 39

Ducker, 49

Duck Hawk, 43, 57

Dull Willy, 82

Dun Bird, 83

Dun Diver, 47

Dun Pickle, 57

Dung Bird, 95

Dunker, 83

Dunlin, 40

Dunlin Sandpiper, 40

Dunnock, 96

Dunter Duck, 38

Dusky Lark, 79

Dykesmavler, 96

Dykie, 96

Eagle, 4I, 42

Eagle Fisher, 70

Eaqual, I20

Easterling, I I 8

Eave Swallow, 65

Ebb, I9

Ecle, I20
Ekimol, 107

Ellygug, 52

Emmet Hunter, I23

English Ortolan, I I 5

Epicurean Warbler, 43

Erne, 42

Eso Cock, 34

Eve-Churr, 68

Evejar, 68

Faceddar, 95

Fachach, 9I

Falcon, 42, 43

Falk, 86

Fallow Chat, I I5

Fallow Finch, I I 5

Fallow Snatch, I I 5

Familiar Creeper, 29

Fauvette, I7, I I I

Feaser, 95

Feather Poke, Io7

Feltie, I03

Fen Eagle, 42

Fern Owl, 68

Fiddler, 8o

Field Lark, 79, 80, 95

Field Titling, 8o

Fiery Bran-Tail, 89

Fig Bird, I I I

Fig-Eater, 44

Fire-Eyed Chat, I Io

Fireflirt, 89

Firetail, 89

Fishing Eagle, 70

Fishing Hawk, 70

Flasher, 93

Flesh Crow, 30

Flitterchack, 7 I

Flycatcher, 43, 44

Foolish Dotterel, 35

Foolish Guillemot, 52

Fool's Coat, 46

Fork-Tailed Glead; 62

Fork-Tailed Kite, 62

French Linnet, 87, I08

French Magpie, 93, 107, 120, I 2 I

French Pigeon, 63

French Woodpecker, 120

French Yellow Hammer, I9 
Fulfar, $\mathrm{I}_{03}$

Furze Chat, I 6

Furze Hacker, 95

Furze Wren, I Io

Gadwall, 44

Gallinule, 67

Gallinule Crake, 28

Gallinule Drake, 28

Gally, I 20

Gambet Sandpiper, S8

Gan, 45

Gannet, 45

Garden Fauvette, I I I

Garden Ousel, I7

Garganey, 46

Gargle Teal, 46

Gaunt, 48

Gay Pie, 60

Geck, 3 I

Gesner's Wood Crow, 25

Gilli-Howlet, 71

Gladdy, 22

Glade, 62

Goat Owl, 68

Goatsucker, 68

Golden Bill, I 7

Golden - Crested

Kinglet, I 22

Golden - Crested

Regulus, 122

Golden - Crested

Warbler, 122

Gold finch, 46

Goldie, 22, 46

Goldspink, 22, 46

Gooldie, 46

Goole, 22

Gool Finch, 22

Goosander, 47

Goose, Grey Lag, 48

Gorcock, 5 I

Gormer, 27

Gorse Linnet, I 6

Gourder, 77

Gowk, 3 I

Grass Chat, I 6

Grasshopper Lark, 80, I I 2

Great Corbie Crow, 86

Great Pied Mountain Finch, 2 I

Great Plover, 33, 50

Great Skua, 94
Great Tern, ro2

Greater Brambling, 2 I

Greater - Crested Douclier, 48

Greater Dabchick, 48

Greater Loon, $4^{8}$

Greater Pettychaps, I I I

Greater Redpoll, 64

Grebe, 48, 49

Greedy Kite, 62

Green Bird, 49

Green Cormorant, 9 I

Greenfinch, 49

Green Grosbeak, 49

Greenland Dove, 52

Green - Legged

Horseman, 50

Green Linnet, 49

Green Plover, 63

Green Scout, 91

Greenshank, 50

Green - Shanked Godwit, 50

Greenulf, 49

Green Wren, II 5

Grey Bird, IO4

Grey Cheeper, 78

Grey Duck, 44

Grey Hen, 50

Grey Kate, 46

Grey Pate, 46

Grey Skit, 85

Grey Wagster, I09

Grosbeak, 58, 96, I I 4

Ground Huck-

Muck, II 4

Ground Wren, $5^{8}$

Grouse, 50, 5I

Guernsey Nightingale, 17

Guillem, 52

Guillemot, 52

Guldenhead, 84

Gull, 53-56

Gull Teaser, $\mathrm{IO}_{2}$

Hagister, 64

Halcyon, 62

Half Curlew, I I 6

Half Nebb, 77

Hanser, 59

Harle Duck, 47

Harnsea, 59

Harpy, 57
Harrier, 56, 57

Hatcher, 96

Hawfinch, 58

Haw Grosbeak, 58

Hawk, Sparrow, 58

Hay Bird, 25, II4, II 5

Haychat, I7, II 7

Haycrake, 28

Hay-Jack, I 7, I I 8

Hay Tit, I I 7

Hazock, 96

Hazock Wren, II 4

Hearinsew, 59

Heath Cock, 50

Heath Poult, 50

Heather Bleat, 96

Heather Cheeper, 78

Heather Lintie, 78 , I 08

Heave Jarr, 68

Heckymal, Io6

Hedge Accentor, 96

Hedge Bettie, 96

Hedge Chanter, 96

Hedge Chat, 96

Hedge Chicken, 96

Hedge Creeper, 96

Hedge Warbler, 96

Heedy Royston, 3 I

Heelin, ro3

Helligag, 86

Hempie, 96

Hermit Crow, 25

Hern, 59

Heron, 59

Heronshaw, 59

Heronswegh, 59

Herring Spink, I22

Hew-Hole, 120

Hickwall, r 05, I 2 I

High Hoe, I 20

Hill Sparrow, 78

Hiogga, 86

Hoarse Gowk, 96

Hobby, 42

Holm Screech, $\mathrm{IO}_{3}$

Holm Thrush, I03

Hooded Maw, 53

Hoodie Crow, 3 I

Hoody, 30

Hoody Bran, 30

Hoop, $x 8$

Horned Dabchick, $4^{8}$

Horned Doucker, 48

Horned Oolert, 73
Horn Finch, 77

Horse-Dung Finch, 24

Horse Lark, I9

Horse Smatch, I 15 , I 6

House Swallow, '65

Howlet, 71, 72,:73

Isle of Wight Parson, $27,9 \mathrm{I}$

Jack, 60

Jack Baker, 93

Jack Curlew, I I 6

Jackdaw', 60

Jack Hern, 59

Jack - in - a - Bottle, I07

Jack Nicker, 46

Jack Saw, I 7, 47

Jack Squealer, roo

Jack Straw, II7, I 8

$\mathrm{Jacob}, 9^{8}$

Jar Bird, 69

Jar Owl, 68

Jay, 60

Jay Piet, 60

Jenny Howlet, 73

Jercock, 103

Jerrybo, 105

Jilliver Wren, 122

Jimpo, 122

Jobbin, 69

Jobbler, I 5

Joe Bent, 106, ros

Joey, 49

Kae, 6 o

Kakera, 35

Kamchatka Tern Lion, 35

Kate, 58

Kate Hern, 59

Kattabella, 56

Keelie, 6I

Kentish Dotterel, 8 I

Kentishman, 3 I

Kestrcl, 6r

Kiddaw, 52

Killingrew, 25

Killockie, 50

Kingfish:r, 62

King Harry, 46

Kinglet, 122

Kip, 102 
Kirktullock, 92

Kirmew, 102

Kite, 62

Knife Bill, 84

Knot Curlew, i 6

Labbe, 95

Lacky-Mo, 28

Lamer, 43

Land Bunting, 19

Land Laverock, 82

Landrail, $2 \mathrm{~S}$

Land Swallow, 65

Lapwing, 63

Larger Willow Wren, II 5

Lark, 95, I 19

Lary, 52

Laverock, 95, I I9

Leach's Petrel, 76

Leader, I 23

Least Snipe, 40

Least Willow Wren, 25

Lesser Butcher Bird, 93, IO4

Lesser Crested Lark, 80

Lesser Dun Diver, 66

Lesser Imber, 34

Lesser Mountain Finch, 2 I

Lesser Pettychaps, 25

Lesser Red-Headed Finch, 87

Lesser Reed Sparrow, II 3

Lesser Sea Swallow, I 22

Lesser Spotted Water Rail, 28

Lesser Toothed Diver, 66

Ling Bird, 78

Linnet, ${ }_{4}$

Lintie, 64

Lintie White, 25, I I 5

Lintwhite, 64, 95

Little BlackHeaded Tomtit, I08

Little Mow, IO2

I.it tle Peter, 77

Little Petrel, 77

Locustelle, I 2

Longpod, ro7
Longtail, 78

Long-Tailed Capon, 107

Long - Tailed Mag, I07

Long - Tailed Mufflin, 107

Long - Tailed Pie, 107

Long Tom, I07

Long Tongue, I23

Loon, 48

Luest, 36

Lumme, 34

Lyne, 9 I

Lyrie, 9 I

Madge, $6_{4}$

Madge Howlett, 7 I

Maggie, 64

Magpie, 64

Malduck, 76

Mallard, 39

Nallemoke, 76

IIalmarsh, 76

Narch Harrier, 57

Marrot, 53, 84, 86

Marsh Hawk, 57

Marsh Hen, 67

Marsh Reedling, I 13

Martin, 65

Martin Du, roo

Martinet, 65

Martin Swallow, 65

Martlet, 65

Marvil, 52

Narygold Finch, 122

Masked Gull, 53

Manx Lyre, 9I

Manx Petrel, 9 I

Manx Puffin, 9r

Mavis, IO4

Nay Bird, I 6

Nay Oolie, 7 I

Meadow Crake, 28

Meadow Lark, 78 , 80

Neadow Titling, 78 , 80

Meg Cut-Throat, II7

Mele, 20

Merganser, RedBreasted, 66

Merle, I7

Merlin, 67

Mew, 53

Michaelmas Blackbird, 7 I

Miller, 44
Miller's Thumb, I 22

Nire Crow, 53

Mire Snipe, 96

Misseler, 103

Missell Bird, I03

Mitty. 77

Mivope, I8

Moat Hen, 67

Nock Bird, I 13

Mock Nightingale, I7

Molrooken, 48

Moll Hern, 59

Molly, 76

Monk, 18

Moonie, I22

Moor Bird, $5 \mathrm{I}$

Moor Blackbird, 7I

Moor Buzzard, 57

Moor Cock, 5I

Moor Coot, 67

Moor Game, 5 I

Monrhen, 67

Noor Lamb, 96

Moor Titling, 78,98

Moss Cheeper, 78

Moth-Eater, 68

Mother Carey's Chicken, 77

Mountain Blackbird, 7 I

Mountain Cock, 23

Mountain Linnet, I08

Mountain Ouzel, I7

Mouse Falcon, 6r

Mouse Hawk, 73

Mud-Dabber, 69

Mudstopper, 69

Muggy, II 7

Muir Fowl, 5 I

Muff, II7

Muffitie, 96

Mufflin, I07

Muftie, II 7

Muftie Wren, I I4

Mullet Hawk, 70

Mullett, 84

Mum Ruffin, I07

Murdering Pie, 93

Murre, 86

Mussell-Picker, 74

Nanny Washtail, rog

Nanpie Pianet, 64

Nettlecreeper, . I7, III, II ?
Nettlemonger, III, II7

Nicker Picker, I2O

Night-Churr, 69

Night Crow, 69

Night Hawk, 33, 69

Nightingale, 68

Nightjar, 68

Night Singer, $\mathrm{Ir}_{3}$

Night Warbler, I I 3

Nimble Tailor, I07

Nine Killer, 93

Nocturnal Goatsucker, 69

Nope, 18

Norfolk Plover, 33

Norie, 27

Northern Doucker, 34

Northern Fulmar, 76

Nun, I05

Nutcracker, 69

Nuthack, 69

Nuthatch, 69

Nutjobber, 69

Nut-Tapper, 69

Oat Fowl, 2 I

Oke, 86

Old Hardweather, 39

Olf, $\mathrm{x} 8$

Olive, 74

'Ollering Owl, 73

Oodal, 36

Osprey, 70

Our Lady's Hen, 95,122

Oussel, I7

Ouzel, Ring, $7 x$

Oven Bird, I I 4

Oven Builder, ro7

Owl, 7 r-73

Ox Bird, 40

Oxeye, 40, 106

Oystercatcher, 74

Oysterpicker, 74

Pandled Whew, II 8

Parson, 27

Partridge, 75

Passage Hawk, 43

Passerine Warbler, I I I

Pay-Pay, 123

Pea Bird, 123

Pea Linnet, 87 
Pease Crow, Ior, Post Bird, 44 IO2, $\mathrm{IO}_{3}$

Peep, 78

Peeseweep, 63

Peewit, 63

Peewit Gull, 53

Peggy Washdish, I09

Peggy Whitethroat, I I 4, I I7

Penny Wagtail, rog

Petrel, 76, 77

Phalarope, 77

Pheasant, 78

Pheasie, 78

Phillip, 7 I

Philomel, 68

Phip, 96

Phirgie, 53

Phragmite, I 3

Pianet, 74

Pick-a-Tree, I20

Pick Cheese, I05, Io6

Picket, 102

Pickmire, 53

Picktarny, $\mathrm{IO}_{2}$

Pie, 74

Pie Finch, 24

Pied Mountain

Finch, 2 I

Pied Oystercatcher, 74

Picd Wigeon, 46

Piet, 34,64

Piet Lintie, 24

Pigeon Hawk, 56, 58

Pinchem, I05

Pink, 24

Pinnock, 96, I04

Pipit, 78-80

Pipit, $78,79,80$

Pipit Lark, 78,80

Pirate, $\mathrm{IO}_{2}$

Pirenct, 92

Pirr, $\mathrm{IO}_{2}$

Pit Martin, 65

Plover, 63

Plover, 81, 82

Plover's Page, 40

Pochard, 83

Poke Pudding, 107

Poker, 83

Pool Snipe, 88

Pope, 18,84

Poppinjay, 120

Port Egmont Heron, 94
Poyet, 64, I03

Proud-Tail, 46

Proud-Tailor, 46

Ptarmigan, 83

Puckeridge, 69

Puffin, 84

Puffinet, 52

Pump-Borer, I 2 I

Pundle, I 8

Purre, 40

Puttock, 23, 57, 62

Pye May, 64

Pyet, 64

Quail, 84

Quaketail, Io9

Queest, 36

Quirck, 48

Quist, 36

Rafter, 44

Ragamuffin, I07

Rail, Water, 85

Rain Bird, 120

Rain Fowl, I20

Rain Goose, 35

Ran, 122

Rattlesnake Bird, I 2

Raven, 86

Ray's Wagtail, I Io

Razorbill, 86

Razor-Billed Auk, 86

Razor-Grinder, II 2

Red - Backed Butcher Bird, 93

Redbreast, 87

Red-Breasted Goon, 66

Red-Breasted Goosander, 66

Redcap, 46

Red-Eyed Poker, 83

Red - Fiery BramTail, 89

Red - Fronted

Thistle Finch, 46

Red Game, 5 I

Red-Headed Finch, 64

Red - Headed

Wigeon, 83

Red Hoop, i 8

Red-Leg, 88

Red - Legged Gull,
Red-Legged Horseman, 88

Red-Legged Jackdaw, 25

Red-Legged Sandpiper, 88

Red-Legs, 53

Red-Necked

Foot, 77

Red-Necked Sandpiper, 40

Redpoll, Lesser, 87

Red Ptarmigan, 5 I

Redshank, 88

Red-Shanks, 25

Redshank Sandpiper, 88

Redstart, 89

Red-Tail, 89

Red Wiggon, 46

Reed Bird, I 3

Reed Fauvette, I I 3

Reed Pheasant, ro4

Reed Sparrow, 20

Reed Wren, II3

Reeler, II 2

Rickel Bird, IO2

Rickim-Re, 53

Rinding Bird, I 23

Ring Bird, 20

Ring Blackbird, 7I

Ring Dow, 36

Ring Fowl, I 6

Ring - Necked Turtle, 33

Ring Pigeon, 36

Ring - Tailed Harrier, 56

Ring Thrush, 7 I

Ringed Dotterel, 82

Ringed Guillemot, 52

Rippock, ro2

River Pie, 34

Robin, 87

Robinet, 87

Rock Grouse, 83

Rockie, Io8

Rockier, 36

Rock Lark, 79

Rock Linnet, ro8

Rock Ouzel, 7 I

Rock Pigeon, 36

Rong Starling, 7 I

Rook, 89

Rose Linnet, 87

Rose Mufflin, 107

Royston Crow, 3 I
Ruddock, 87

Runner, 85

St. Cuthbert's

Duck, 38

Sally Picker, 25, II 3, II 4

Sand Cock, 88

Sand Lark, 82, 90

Sand Laverock, 82

Sandpiper, 90

Sand Snipe, 90

Sand Swallow, 65

Sand Thrush, 34

Sandy Laverock. 90

Sandy Loo, 82

Sawbill, 47, 66

Saw Neb, 66

Saw Sharpener, гоб, I 08

Scaber, 52

Scale Drake, 92

Scallop Toe, 77

Scarf, 91

Scobby, 22

Scobby Scraye, IO2

Scobly Buck Finch, 24

Scolder, 74

Scopper-Bill, 92

Scorey, 55

Scotch Canary, 22

Scotch Wren, II 4

Scoter, 90

Scoulton Gull, 53

Scout, 52, 86

Scoutie-Allan, 95

Scrage, 102

Scrapire, 9 I

Screamer, roo

Screech Martin, roo

Screech Owl, 7 I

Scremerston Crow, 3 I

Scribuling Lark, I9, 22

Scutty, I22

Sea Cob, 53

Sea Crow, 25, 27, 53,86

Sea Eagle, 42, 70

Seagull, 53-56

Sea Hen, 52

Sea Lark, 40, 79

Sea Lintie, 79

Sea Magpie, 74

Sea Mall, 53 
Sea Maw, 53

Sea Parrot, 84

Sea Pigeon, 52

Sea Snipe, 40

Sea Swallow, ro2

Sea Tit, 79

Sea Turtle, 52

Sedge Bird, II 3

Sedge Marine, I $x_{3}$

Sedge Reedling, I I 3

Seed Bird, I ro

Seven - Coloured Linnet, 46

Seven Whistler, $x 16$

Shad Bird, 90

Shag, 9I

Shamcider, II 3

Shearwater, 84

Shearwater, Manx, 9 I

Shearwater Petrel, 9 I

Sheeprack, 98

Sheep Stare, 98

Sheep Starling, 98

Shelder, 74

Sheldrake, 92

Shell Apple, 22, 30

Shell-Duck, 92

Shell Turner, 82

Shepherd Bird, I I 5

Shepster, 98

Sheriff's Man, 46

Shield Apple, 30

Shilfa, 22, 24

Shilty Cock, 85

Shore Bird, 65

Shore Lark, 79

Shore Pipit, 79

Short-Heeled Field Lark, 80

Short-Horned Owl, 73

Shovel-Bill, 92

Shoveler, 92

Shreitch, $\mathrm{IO}_{3}$

Shrike, 93

Shrike-Cock, Io3

Shrite, IO3

Shuffle-Wing, 96

Silver Wren, II4, II7

Singing Skyrocket, I I 5, I I 7

Siskin, 94

Skart, 27

Skeel-Duck, 92

Skeeling Goose, 92
Skeer Devil, roo

Skelder Drake, 74

Skelgoose, 92

Skelly, 22, 24

Skerrek, IO2

Skidden, 9 I

Skiddy Cock, 85

Skirl-Cock, IO3

Skite, 22

Skitty, 28

Skort, 86

Skrabe, 84, 9 I

Skua, 94

Skua Gull, 94

Skylark, 95

Sly Goose, 92

Small Doucker, 49

Small Pudding, 49

Smaller Oxeye, Io8

Smallest Willow Wren, 25

Smew, I I 4

Snake Bird, 123

Snipe, 96

Snite, 96

Snorter, II 5

Snow Bird, 93

Snow Chick, 83

Snow Fowl, 2 I

Snowflake, 2 I

Snow Hammer, 2 I

Solan Goose, 45

Solitary Thrush, 98

Song Linnet, 64

Spagger, 97

Spalding Fowl, 47

Sparrow, 96, 97

Speckled Diver, 35

Speckled Loon, 34

Speckled Stare, 98

Speckled Water Hen, 28

Spency, 77

Spink, 24

Spoon-Bill, 92

Sporre, IO2

Spotted Falcon, 43

Spotted Gallinule, 28

Spotted Guillemot, 52

Spotted Rail, 28

Spotted Water Hen, 28

Sprat Loon, 35

Spratoon, 35

Sprug, 97

Squealer, roo
Stag, 122

Standgale, 6 I

Stannel, 6r

Stannel Hover-

hawk, 6r

Stare, 98

Starling, $9^{8}$

Star Thrush, 98

Steingall, 6r

Stenikle, I 5

Stint, 40

Stock Chacker, I9

Stock Duck, 39

Stock Pigeon, 37

Stock Whaap, 32

Stocking Weaver, I 9

Stonechack, 98, I I 5, II 6

Stonechat, 98

Stonechink, 98

Stone Falcon, 67

Stonegall, 6I

Stone-Hatch, 82

Stone Plover, 33, 82

Stone Redpole, 87

Stone Runner, 82

Stonesmith, 98

Storm-Cock, $\mathrm{IO}_{3}$

Storm Finch, 77

Strany, 52

Strawsmeer, II 7

Summer Duck, 46

Summer Lamb, 96

Summer Snipe, 90

Summer Teal, Ioo

Surf Tern, IO3

Swabie, 54

Swallow, 99

Swan, roo

Swat-Back, 54

Sweet William, 46

Swift, roo

Swift Swallow, roo

Tame Swan, Ioo

Tammy Norie, 84

Tang Whaap, I 6

Tarney, I02

Tarrack, IO2

Tarret, IO2

Tarrock, 52, 55

Tassel, 43

Tawny Bunting, 2 I

Teachet, 63

Teal, IOI

Teaser, 94, 95

Teetan, 78
Teetick, 78

Tee-Whaup, 63

Tee-Whit, 63

Tern, IOI-IO3

Terste, 52

Teuchit, 63

Teuke, 88

Thick-Knee, 33

Thistle Cock, I9

Thistle Finch, 46

Thrice-Cock, I03

Throstle, ro4

Thrush, I03, I04

Thrusher, I04

Thummie, 25

Tidley Creeper,'́122

Tidley Finch, I22

Ting Hoop, 18

Tink, 24

Tinkershire, 52

Tinker's Hue, 52

Tippet Grebe, $4^{8}$

Tirma, 74

Tit, 104-108

Titlark, 79, 80

Titling, 31, 79, 96

Titmall, ro5

Titteril, II6

Titty Dodger, $\mathbf{2} 22$

Toadsnatcher, 20

Toist, 52

Tom Collier, ro6

Tommi-Liden, 87

Tommy Noddy, 84

Tommy Tomnoddy, 84

Tom Thumb, I I4

Tomtit, I05, I06, I 22

Toney Hoop, I8

Tongue Bird, I20, I 23

Tony, I8

Took, 88

Tor Ouzel, 7 I

Tot-o'er-Seas, I 22

Tree Climber, 29

Tree Huck - Muck, I07

Tree Lark, 8o

Trithcham, 74

Tuet Flopwing, 63

Tufted Pochard, 39

Tufted Wigeon, 39

Tuliac, 94

Tunnock, ro5

Turkey Bird, I 23

Tweed, 87 


\section{BRITISH NESTING BIRDS}

Twite, 108

Twite Finch, ro8

Tyste, 52

Umber Gull, 54

Utick, I I 6

Velvet Runner, 85

Vraun, I22

Wagel, 54

Wag Tail, 40

Wagtail, ro9, Iro

Wall Bird, 44

Wall Hick, I 2 I

Wandering Quail, 84

Wangtail, rog, Iro

Warbler, IIO-II 5

War Cock, 85

Wash Dish, rog

Washer Disher, ro9

Water Blackbird, 34

Water Colly, 34

Water Crake, 28, 34

Water Crow, 34

Water Hen, 67

Water Linnet, 79

Water Ousel, 34

Water Pyet, 34

Water Smith, 34

Water Sparrow, 20, I I 3

Water Thrush, 34

Weet Weet, 90

Wekeen, 79

Wet Bird, 24
Wet-wet-morewet, I 20

Whaap, 32, II 6

Whantie, II 7

Wheatear, I 5

Wheel Bird, 69

Wheetie, II 7

Whet-Ile, I 20

Whew Duck, I I 8

Whilk, 90

Whimbrel, II 6

Whin, II 8

Whin Bushchat, I 6

Whinchat, I 6

Whin Linnet, 64

Whisker Bird, I9

Whiskey, II 7 , I 22

Whiskey John, 93

Whistler, $7 \mathrm{I}$

Whistling Dick, I04

Whistling Plover, $33,8 \mathrm{I}$

White - Backed Dove, 36

White Baker, 44

Whitecap, 89, I I 7

White Daw, IOI, I02

White-Faced Crow, 89

White-Fronted Redstart, 89

White Game, 83

White Hawk, 56

White - Headed Harpy, 57

White Lintie, II

Whiterump, II 5

White Spoonbill, 92
Whitetail, I 5

Whitethroat, I I 7, I 8 Wood Pigeon, 36,

White - Throated Blackbird, 7r

White Wall, 44

White Wing, 44

White Wren, II4, I I7, I 22

Whit Finch, 24

Whitterick, 32

Whitwall, I 20

Whole Snipe, 96

Wideawake, 82

Wigeon, I 8

Wild Goose, 48

Willie Muftie, II4, II 5

Willock, 52, 84, 86

Willow Bite, I 23

Willow Biter, ro8

Willow Wren, II 4

Willy Wicket, 90

Windhover, 6I

Winter Bonnet, 54

Winter Fauvette, 96

Winter Mew, 54

Witchuck, 65

Wittle, I2O

Woodcock, I Io

Woodcock Pilot, 73, I 22

Woodcracker, 69

Wood Grouse, 23

Woodlark, I I 9

Wood Lueest, 36

Woodnacker, I20

Woodpecker, 120, I 2 I
37

Woodspite, I 20

Wood Titmouse, I 22

Woodwall, r 20

Woodwell, I 9

Wood Wren, I I5

Wrannock, 122

Wranny, r 22

Wren, I 22, I 23

Wren Lintie, I I 4

Writing Lark, I9, 22

Wryneck, 123

IVynkerrell,;88

Yaffer, I 20

Yaffingale, I 20

Yaffle, I20

Yappingale, I 20

Yawkle, I 20

Yeldrin, 22

Yeldrock, 22

Yellow Fulfar, I03

Yellow Hammer, 22

Yellow IVagster, I Io

Yellow Warbler, I I 4 , II 5

Yellow Wren, I I 4, I 5

Yellow Yeldring,'22

Yellow Yeldrock, 22

Yellow Yeorling, 22

Yelly, 22

Yelper, 88

Yoit, 22

Yoldring, 22 




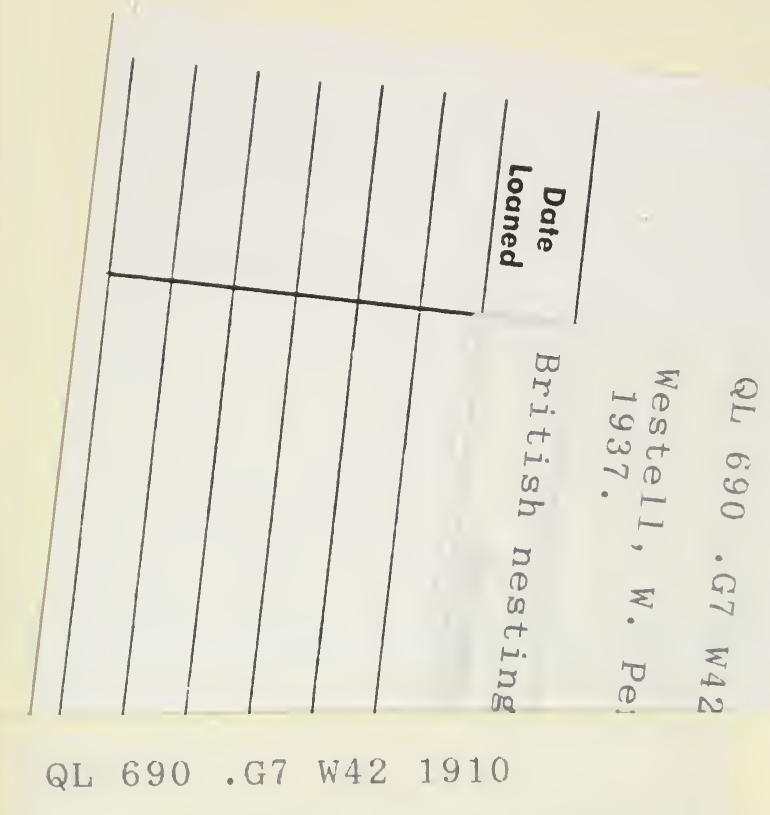

Westell, W. Percival 18741937 .

British nesting birds 
